
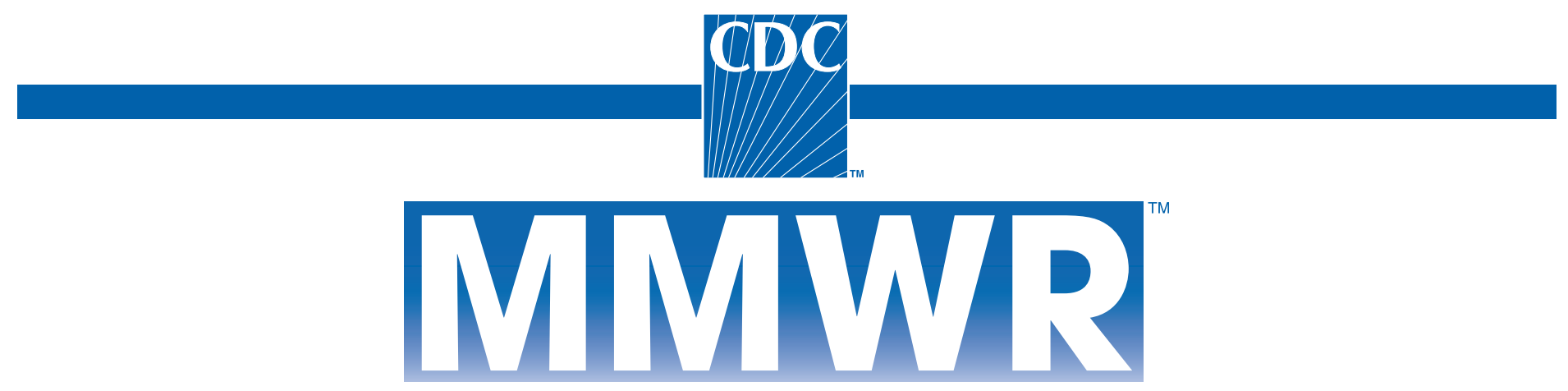

Morbidity and Mortality Weekly Report

www.cdc.gov/mmwr

Weekly

June 5, 2009 / Vol. 58 / No. 21

\title{
Prevalence of Diagnosed Tourette Syndrome in Persons Aged 6-17 Years - United States, 2007
}

Tourette syndrome (TS) is an inheritable, childhood-onset neurologic disorder marked by persistent multiple motor tics and at least one vocal tic (1).* Tics are involuntary, repetitive, stereotypic movements or vocalizations that are usually sudden and rapid and often can be suppressed for short periods (1). The prevalence of TS is uncertain; the broad range of worldwide estimates, from $1-30$ per 1,000 population $(2,3)$, likely is the result of differences in study methodology. This report presents the first estimate of national prevalence of diagnosed TS among a national sample of U.S. children and adolescents aged 6-17 years. Based on data from the 2007 National Survey of Children's Health (NSCH) (4), the estimated prevalence of a lifetime diagnosis of TS by parent report was 3.0 per 1,000 . A diagnosis of TS was almost three times as likely for boys as girls, twice as likely for persons aged 12-17 years than for those aged 6-11 years, and twice as likely for non-Hispanic white persons than for Hispanic and non-Hispanic black persons. Among persons ever diagnosed with TS, 79\% also had been diagnosed with at least one co-occurring mental health or neurodevelopmental condition. CDC sponsors efforts by the Tourette Syndrome Association to educate health-care providers and school personnel about TS to ensure earlier identification and promote appropriate medical, educational, and comprehensive behavioral interventions for children with TS and co-occurring mental health or neurodevelopmental conditions.

The 2007 NSCH was the first national, population-based survey of persons aged $<18$ years that included questions on

\footnotetext{
* Diagnostic criteria for Tourette syndrome include 1) the presence of multiple motor and one or more vocal tics at some time during the illness, although not necessarily concurrently; 2) occurrence of tics many times a day, nearly every day, or intermittently throughout a period of more than 1 year, with no tic-free period of more than 3 consecutive months; 3 ) onset before age 18 years; and 4) symptoms not caused by direct physiologic effects of a substance or a general medical condition (1).
}

TS (4). NSCH is a random-digit-dialed telephone (landline only) survey used to estimate the prevalence of a variety of child health and well-being indicators for every state and to examine these indicators together with information on family characteristics and neighborhood environment. ${ }^{\dagger}$

Telephone interviews $(\mathrm{N}=91,642)$ were completed with parents (or guardians) from April 2007 through July 2008. One child was randomly selected from each household to be the focus of the interview. Complete data on TS were available for 64,034 persons aged $6-17$ years. The overall response rate was $46.7 \%$; the cooperation rate was $66.0 \% .{ }^{\S}$ Data were weighted to account for unequal probability of selection of each household and child, for nonresponse, and for households without landline telephones. Weights were adjusted further so that estimates reflected the demographic distribution of

\footnotetext{
†dditional information about NSCH is available at http://www.cdc.gov/nchs/ about/major/slaits/nsch07.htm. National and state-based estimates for more than 100 indicators from the $\mathrm{NSCH}$ are available at http://nschdata.org.

$\S$ The response rate is the percentage of households that completed interviews among all eligible households, including those that were not successfully contacted. The cooperation rate is the percentage of households that completed interviews among all eligible households that were contacted. $\mathrm{NSCH}$ attempts to minimize nonresponse bias by incorporating nonresponse adjustments in the development of the sampling weights.
}

\section{INSIDE}

585 Update: Novel Influenza A (H1N1) Virus Infection Mexico, March-May, 2009

589 Incidence and Diagnoses of HIV Infection - Puerto Rico, 2006

591 Impact of New WHO Growth Standards on the Prevalence of Acute Malnutrition and Operations of Feeding Programs - Darfur, Sudan, 2005-2007

594 Notice to Readers 
The MMWR series of publications is published by the Coordinating Center for Health Information and Service, Centers for Disease Control and Prevention (CDC), U.S. Department of Health and Human Services, Atlanta, GA 30333.

Suggested Citation: Centers for Disease Control and Prevention. [Article title]. MMWR 2009;58:[inclusive page numbers].

\section{Centers for Disease Control and Prevention}

Richard E. Besser, MD

(Acting) Director

Tanja Popovic, MD, PhD

Chief Science Officer

James W. Stephens, PhD

Associate Director for Science

Steven L. Solomon, MD

Director, Coordinating Center for Health Information and Service Jay M. Bernhardt, PhD, MPH

Director, National Center for Health Marketing

Katherine L. Daniel, PhD

Deputy Director, National Center for Health Marketing

Editorial and Production Staff

Frederic E. Shaw, MD, JD

Editor, MMWR Series

Christine G. Casey, MD

Deputy Editor, MMWR Series

Robert A. Gunn, MD, MPH

Associate Editor, MMWR Series

Teresa F. Rutledge

Managing Editor, MMWR Series

Douglas W. Weatherwax

Lead Technical Writer-Editor

Donald G. Meadows, MA

Jude C. Rutledge

Writers-Editors

Martha F. Boyd

Lead Visual Information Specialist

Malbea A. LaPete

Stephen R. Spriggs

Visual Information Specialists

Kim L. Bright, MBA

Quang M. Doan, MBA Phyllis H. King

Information Technology Specialists

\section{Editorial Board}

$$
\begin{gathered}
\text { William L. Roper, MD, MPH, Chapel Hill, NC, Chairman } \\
\text { Virginia A. Caine, MD, Indianapolis, IN } \\
\text { David W. Fleming, MD, Seattle, WA } \\
\text { William E. Halperin, MD, DrPH, MPH, Newark, NJ } \\
\text { King K. Holmes, MD, PhD, Seattle, WA } \\
\text { Deborah Holtzman, PhD, Atlanta, GA } \\
\text { John K. Iglehart, Bethesda, MD } \\
\text { Dennis G. Maki, MD, Madison, WI } \\
\text { Sue Mallonee, MPH, Oklahoma City, OK } \\
\text { Patricia Quinlisk, MD, MPH, Des Moines, IA } \\
\text { Patrick L. Remington, MD, MPH, Madison, WI } \\
\text { Barbara K. Rimer, DrPH, Chapel Hill, NC } \\
\text { John V. Rullan, MD, MPH, San Juan, PR } \\
\text { William Schaffner, MD, Nashville, TN } \\
\text { Anne Schuchat, MD, Atlanta, GA } \\
\text { Dixie E. Snider, MD, MPH, Atlanta, GA } \\
\text { John W. Ward, MD, Atlanta, GA }
\end{gathered}
$$

noninstitutionalized U.S. children and adolescents from the 2007 American Community Survey of the U.S. Census Bureau.

Parents were asked, "Has a doctor or other health-care provider ever told you that [your child] had Tourette syndrome?" Affirmative responses were followed by asking whether the child currently has TS, and if so, whether the parent would describe the child's TS as mild, moderate, or severe (severity was only assessed for current TS). The same series of questions (e.g., current or ever doctor diagnosis) were asked about other co-occurring conditions, including attention-deficit/ hyperactivity disorder (ADHD), depression, anxiety problems, behavioral or conduct problems such as oppositional defiant disorder or conduct disorder, and developmental delays affecting a child's ability to learn. Prevalence of parent-reported TS diagnosis (ever and current) among U.S. children, presence of co-occurring conditions, and severity of symptoms among children with current TS were calculated using statistical analysis software to account for the complex sampling design of NSCH.

All estimates in this report reflect persons aged 6-17 years. Estimates for children aged $<6$ years had high relative standard errors $(>0.3)$ and are not reported. The estimated prevalence for ever receiving a TS diagnosis, by parent report, was 3.0 per 1,000 , representing approximately 148,000 children $(95 \%$ confidence interval $[\mathrm{CI}]=111,000-197,000)$ (Table) in the United States. A diagnosis of TS was approximately three times as likely for boys compared with girls, and approximately twice as common in persons aged 12-17 years compared with those aged 6-11 years. Non-Hispanic white children were twice as likely as non-Hispanic black children and Hispanic children to have a parent-reported TS diagnosis. No differences were noted by parental education or household income. Among children ever diagnosed with TS, 79\% also had been diagnosed with at least one co-occurring mental health or neurodevelopmental condition (Figure): $64 \%$ had been diagnosed with ADHD, $43 \%$ with behavioral or conduct problems, $40 \%$ with anxiety problems, $36 \%$ with depression, and $28 \%$ with a developmental delay affecting the child's ability to learn.

Among children with a TS diagnosis, 62\% (weighted $\mathrm{N}=$ approximately $92,000, \mathrm{CI}=65,000-131,000$ ) were described as currently having TS. Most current cases were described as mild, and $27.1 \%(\mathrm{CI}=15.0-43.8)$ were rated as moderate or severe. Persons aged 6-13 years were more likely than those aged $14-17$ years to currently have TS ( $82.6 \%$ versus $42.1 \%$, $\mathrm{p}<0.01)$. Differences between the $6-11$ years and $12-17$ years age groups were not statistically significant.

Reported by: L Scahill, PhD, Yale Univ Child Study Center and School of Nursing. RH Bitsko, PhD, SN Visser, MS, Div of Human Development and Disability, National Center on Birth Defects and 
TABLE. Prevalence of ever receiving a diagnosis of Tourette syndrome among persons aged 6-17 years, by selected characteristics* - National Survey of Children's Health, United States, 2007

\begin{tabular}{|c|c|c|c|c|c|c|}
\hline Characteristic & $\begin{array}{l}\text { No. in sample } \\
\text { (unweighted) }^{\dagger}\end{array}$ & $\begin{array}{l}\text { No. with reported } \\
\text { diagnosis } \\
\text { (unweighted) }\end{array}$ & $\begin{array}{c}\text { Weighted } \\
\text { prevalence per } \\
1,000\end{array}$ & $\left(95 \% \mathrm{Cl}^{\S}\right)$ & $\begin{array}{l}\text { Prevalence } \\
\quad \text { ratio }\end{array}$ & $(95 \% \mathrm{Cl})$ \\
\hline Total surveyed & 64,034 & 225 & 3.0 & $(2.3-4.0)$ & - & - \\
\hline \multicolumn{7}{|l|}{ Age (yrs) } \\
\hline $6-11$ & 27,776 & 61 & 1. 9 & $(1.2-2.9)$ & Referent & Referent \\
\hline $12-17$ & 36,258 & 164 & 4.0 & $(2.8-5.9)$ & 2.1 & $(1.2-3.8)$ \\
\hline \multicolumn{7}{|l|}{ Sex } \\
\hline Male & 33,264 & 179 & 4.4 & $(3.2-6.1)$ & 2.9 & $(1.4-6.0)$ \\
\hline Female & 30,680 & 46 & 1.5 & $(0.8-2.9)$ & Referent & Referent \\
\hline \multicolumn{7}{|l|}{ Ethnicity/Race } \\
\hline Hispanic & 7,347 & 26 & 1.6 & $(0.9-2.8)$ & 0.4 & $(0.2-0.8)$ \\
\hline Non-Hispanic white & 43,766 & 164 & 3.9 & $(2.7-5.6)$ & Referent & Referent \\
\hline Non-Hispanic black & 6,445 & 18 & 1.5 & $(0.9-2.7)$ & 0.4 & $(0.2-0.8)$ \\
\hline \multicolumn{7}{|l|}{$\begin{array}{l}\text { Highest level of education achieved } \\
\text { by parent in household }\end{array}$} \\
\hline High school diploma or less & 14,902 & 58 & 3.5 & $(2.0-6.0)$ & 1.3 & $(0.7-2.4)$ \\
\hline At least some college or technical school & 48,376 & 165 & 2.7 & $(2.0-3.8)$ & Referent & Referent \\
\hline \multicolumn{7}{|l|}{ Household income } \\
\hline$\leq 200 \%$ of federal poverty level (FPLף) & 17,646 & 65 & 3.1 & $(1.8-5.2)$ & 1.1 & $(0.4-3.2)$ \\
\hline$>200 \%$ to $\leq 400 \%$ above FPL & 21,875 & 80 & 3.0 & $(1.8-5.1)$ & 1.0 & $(0.3-3.2)$ \\
\hline$>400 \%$ above FPL & 24,512 & 80 & 2.9 & $(1.9-4.4)$ & Referent & Referent \\
\hline
\end{tabular}

${ }^{*}$ As reported by parents.

${ }^{\dagger}$ The sum of the sample sizes might not equal the total surveyed because some parents did not know or refused to provide an answer to the question about the characteristic. Missing data for family income were derived using multiple imputation techniques (4). Missing data for other characteristics were not imputed.

$\S$ Confidence interval.

ๆ Poverty guidelines for 2007 available at http://aspe.hhs.gov/poverty/07fedreg.pdf.

Developmental Disabilities; SJ Blumberg, PhD, Div of Health Interview Statistics, National Center for Health Statistics, CDC.

Editorial Note: Worldwide estimates of TS from populationbased studies have ranged from 1 to 30 per 1,000 persons $(2,3,5)$. This wide variation likely results from differences in sample size, population source, sample age, diagnostic criteria, and study methods (e.g., parent report, teacher report, and direct observation). TS prevalence described in recent community-based studies ranges from $3.0-8.0$ per 1,000 persons $(3,5-7)$.

This report provides the first prevalence estimate of diagnosed TS based on parent report from a nationally representative sample of U.S. children and adolescents. TS is a neurologic condition with genetic predisposition and childhood onset. Tic severity often peaks in adolescence and often declines by early adulthood (8). TS is more common in boys than girls $(1-3,9)$. Children with TS experience associated problems related to academic and work performance and family and peer relationships (3). A TS diagnosis might be delayed or missed if symptoms are atypical, mild, attributed to alternate etiology (e.g., blinking mistaken for visual problem or sniffles mistaken for seasonal allergies), or in children with limited access to specialty health care (e.g. pediatric neurologist or child psychiatrist).
FIGURE. Prevalence of selected diagnoses* among persons aged 6-17 years who have ever received a diagnosis of Tourette syndrome (TS), ${ }^{\dagger}$ by parent report — National Survey of Children's Health, United States, 2007

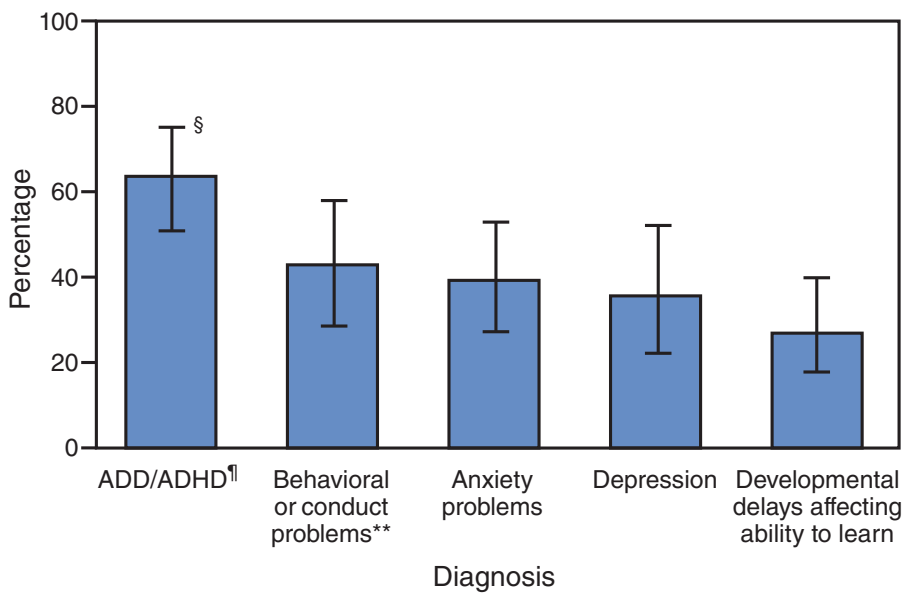

* Selected diagnoses included mental health and neurodevelopmental conditions asked about on the survey, including attention-deficit/hyperactivity disorder (ADHD), behavioral or conduct problems, anxiety problems, depression, and developmental delays.

${ }^{\dagger}$ Among children ever diagnosed with TS, 79\% also had been diagnosed with at least one other selected diagnosis. Among children who currently have TS, $73 \%$ currently have at least one additional selected diagnosis.

§ $95 \%$ confidence interval.

I Attention-deficit disorder or attention-deficit/hyperactivity disorder, by parent report.

** Such as oppositional defiant disorder or conduct disorder, by parent report. 
Many studies have reported male-to-female TS prevalence ratios of at least $4: 1(3,9,10)$. This is consistent with the higher prevalence of TS diagnosis among boys observed in the NSCH data. The reason boys are more likely than girls to express symptoms of TS is unclear and is likely the result of a combination of genetic, hormonal, and environmental factors $(1,8)$.

The higher lifetime prevalence among older children is consistent with the known age distribution. Although average age of tic onset is 5-7 years, the course is often insidious (8). Severity often peaks between ages 10 and 12 years (8). Thus, the onset of TS symptoms might not be recognized immediately by parents or diagnosed by a clinician. After tic severity peaks, it might decline sufficiently that parents will no longer report that their child has TS. Among all children ever receiving a TS diagnosis, current TS was less likely to be reported for persons aged 14-17 years. However, impairment can endure into adulthood (8), and early identification and intervention might improve social, educational, and employment outcomes for persons with TS.

Consistent with community-based studies $(2,9)$, approximately three fourths of children in this study with a current TS diagnosis had mild TS, according to their parents. Even when TS is mild, however, commonly associated co-occurring conditions such as ADHD and obsessive compulsive disorder might contribute to overall impairment $(2,10)$.

The survey-based prevalence estimate described in this report is based on parent report of a TS diagnosis. The detection and diagnosis of TS is less likely for children with limited access to specialty health-care services (2). Thus, the observed surveybased prevalence of 3.0 per 1,000 likely is an underestimate of TS prevalence in children. Results from community-based studies that independently evaluate children for TS and do not rely on parent-reported diagnosis invariably identify cases that were previously not diagnosed $(3,6,9)$. In addition, many children identified as having TS in community-based studies were not receiving mental health services $(2,6,9)$. This suggests that primary-care practices and schools might be important settings to improve recognition and referral.

The survey-based prevalence estimates revealed that nonHispanic black children and Hispanic children had a lower probability of TS diagnosis compared with non-Hispanic white children. Community-based studies of TS have lacked adequate sample size to determine prevalence for racial or ethnic groups. Differences in the prevalence of TS among racial and ethnic groups might result from biologic risk or disparities in access to specialty health care. The gap between prevalence reported in community-based studies and surveybased prevalence described in this report among non-Hispanic blacks and Hispanics is greater than the gap between reports from community-based studies and the survey-based prevalence among non-Hispanic whites. These gaps support the view that differences in reported prevalence are at least partially attributable to differences in access to care. The lack of association between income and parent education with TS diagnosis suggests that other factors might affect the racial and ethnic differences. Research in communities with adequate representation of minority and underserved populations is needed to clarify the reasons for the differences in prevalence.

The findings in this report are subject to at least four limitations. First, symptoms consistent with TS must be recognized to establish a diagnosis. Some cases might remain undetected because of lack of awareness or access to medical care. Second, families who did not speak English, Spanish, or one of four Asian languages (Cantonese, Korean, Mandarin, or Vietnamese) were excluded from the survey (4). Third, the presence of co-occurring conditions and reported severity might be subject to recall error. Finally, the results are subject to biases associated with telephone surveys, including the exclusion of households without landlines and low response rates relative to population-based, face-to-face surveys.

Impairment in learning, school performance, and social competence can result from tics or co-occurring conditions (2). Clinical assessment and treatment of children with TS warrants attention to tics and co-occurring conditions to reduce overall impairment. The degree of impairment and spectrum of co-occurring conditions varies and therefore the treatment should be tailored to address the individual's type and severity of symptoms. Assessment by a specialist (e.g. pediatric neurologist or child psychiatrist), might provide the best available treatment options (e.g., behavioral or pharmacologic interventions). If academic or behavioral performance is of concern, referrals for educational interventions designed to reduce the effect of tics and co-occurring disruptive behavioral problems on learning should be considered.

Defining lifetime prevalence is an important step in defining the public health impact of TS. Although symptoms of TS might disappear in some cases by early adulthood, symptoms of co-occurring conditions can persist. CDC is conducting surveillance, research, and outreach activities to document the impact of TS and improve its recognition. CDC sponsors the Tourette Syndrome Association to provide authoritative education for physicians and allied health care workers, including school personnel, about TS treatment and the effects of the disorder. The programs increase access to accurate and scientifically valid information on the recognition, diagnosis, and treatment of TS, with a view toward improved health and developmental outcomes. 


\section{Acknowledgments}

This report is based, in part, on contributions from Maternal Child Health Bur, Health Resources and Svcs Admin, US Dept of Health and Human Svcs.

\section{References}

1. American Psychiatric Association. Diagnostic and statistical manual of mental disorders: DSM-IV-TR. 4th ed. Washington, DC: American Psychiatric Association; 2000.

2. Scahill L, Sukhodolsky DG, Williams SK, Leckman JF. Public health significance of tic disorders in children and adolescents. Adv Neurol 2005;96:240-8.

3. Khalifa N, von Knorring AL. Prevalence of tic disorders and Tourette syndrome in a Swedish school population. Dev Med Child Neurol 2003;45:315-9.

4. Blumberg SJ, Foster EB, Frasier AM, et al. Design and operation of the National Survey of Children's Health, 2007. Vital Health Stat 1 (in press).

5. Stefanoff P, Wolanczyk T, Gawrys A, et al. Prevalence of tic disorders among schoolchildren in Warsaw, Poland. Eur Child Adolesc Psychiatry 2008; 17:171-8

6. Hornsey H, Banerjee S, Zeitlin H, Robertson M. The prevalence of Tourette syndrome in 13-14-year-olds in mainstream schools. J Child Psychol Psychiatry 2001;42:1035-9.

7. Scahill L, Williams S, Schwab-Stone M, Applegate JO, Leckman JF. Tic disorders and disruptive behavior in a community sample. Adv Neurol 2006;99:184-90.

8. Leckman JF, Zhang H, Vitale A, et al. Course of tic severity in Tourette syndrome: the first two decades. Pediatrics 1998;102:14-9.

9. Kadesjo B, Gillberg C. Tourette's disorder: epidemiology and comorbidity in primary school children. J Am Acad Child Adolesc Psychiatry 2000;39:548-55.

10. Sukhodolsky DG, Scahill L, Zhang H, et al. Disruptive behavior in children with Tourette's syndrome: association with ADHD comorbidity, tic severity, and functional impairment. J Am Acad Child Adolesc Psychiatry 2003;42:98-105.

\section{Update: Novel Influenza A (H1N1) Virus Infection - Mexico, March-May, 2009}

On April 12, 2009, Mexico responded to a request for verification by the World Health Organization (WHO) of an outbreak of acute respiratory illness in the small community of La Gloria, Veracruz. During April 15-17, the Mexico Ministry of Health received informal notification of clusters of rapidly progressive severe pneumonia occurring mostly in Distrito Federal (metropolitan Mexico City) and San Luis Potosi. In response, on April 17, Mexico intensified national surveillance for acute respiratory illness and pneumonia. During April 22-24, novel influenza A (H1N1) virus infection, previously identified in two children in the United States (1), was confirmed in several patients. This report updates a previous report (2) on the outbreak in Mexico and summarizes public health actions taken to date by Mexico to monitor and control the outbreak. During March 1-May 29, national surveillance identified 41,998 persons with acute respiratory illness; specimens from 25,127 (59.8\%) patients were tested, of which $5,337(21.2 \%)$ were positive for novel influenza A (H1N1) virus infection by real-time reverse transcription-polymerase chain reaction (rRT-PCR). As of May 29, 97 patients with laboratory-confirmed infection had died. Epidemiologic evidence to date suggests that the outbreak likely peaked nationally in late April, although localized cases continue to be identified.

\section{Enhanced Surveillance}

The outbreak of acute respiratory illness in La Gloria, Veracruz (population 2,155), was characterized by a large number of cases (616 or $28.5 \%$ of the population) reported during March 5-April 10. This outbreak was likely of mixed cause; later testing of respiratory specimens collected during this period identified two patients as positive for seasonal influenza A (H3N2), one for seasonal influenza B, and one patient for novel influenza A (H1N1) virus with an adenovirus coinfection. Most of the respiratory illnesses from this outbreak remain undiagnosed; no severe cases or deaths were observed.

During March and April, 47 cases of rapidly progressive severe pneumonia were identified from clusters in Mexico City, San Luis Potosi, and other cities. Twelve deaths were reported; in four of the deaths, specimens were positive for novel influenza A (H1N1) infection. In response to the La Gloria outbreak and the pneumonia clusters, the National Committees for Epidemiological Surveillance and Emerging Infectious Disease released an epidemiologic alert on April 17 to enhance national surveillance for acute respiratory illness and severe pneumonia. This enhanced surveillance was implemented through active case finding in hospitals throughout the country, including daily zero-reporting (requiring facilities and jurisdictions to report even if no suspected cases had been identified) and monitoring of news media and other sources. The Mexico Ministry of Health also initiated investigations of outbreaks throughout the country, with the assistance of the WHO Global Outbreak and Alert Response Network, coordinated by the Pan American Health Organization.

During April 18-19, a survey conducted in 23 hospitals in Mexico City indicated increased pneumonia-related hospital admissions since April 10, particularly among young adults. On April 21, respiratory specimens collected as a result of these enhanced surveillance activities were sent to the National Microbiology Laboratory of the Public Health Agency of Canada and to the Influenza Division at CDC. During April 22-24, both laboratories identified novel influenza A (H1N1) virus in specimens from Mexican patients. The Directorate General of Epidemiology (DGE) established an Internet-based 
reporting platform to collect case-based epidemiologic information and a daily epidemiologic bulletin to disseminate results of ongoing investigations and recommendations from DGE. The first release of this bulletin occurred on April 26.

After identification of novel influenza A (H1N1) virus infection in Mexico, a case definition was developed. The initial definition of suspected novel influenza A (H1N1) virus infection included any hospitalized patient with severe acute respiratory illness. On May 1, this definition was expanded to include any person with acute respiratory illness defined as fever and either sore throat or cough. On May 11, the definition of suspected case was changed again to include any person with fever, cough, and headache, plus at least one of the following: rhinorrhea, coryza, arthralgia, myalgia, prostration, sore throat, chest pain, abdominal pain, or nasal congestion. In children aged $<5$ years, irritability replaced headache. A laboratory-confirmed case of novel influenza $A(\mathrm{H} 1 \mathrm{~N} 1)$ virus infection was defined as illness in any person who had a respiratory specimen that tested positive for novel influenza A (H1N1) by rRT-PCR.

During 2008, to comply with new international health regulations, Mexico increased its number of influenza sentinel sites from 380 to 520 and expanded influenza testing capacity to four additional states. Enhanced surveillance for novel influenza A (H1N1) cases in mid-April 2009 generated an increase in the number of clinical specimens collected from patients with acute respiratory illness and a surge in testing at the National Laboratory from approximately 30 specimens to 900 daily. Enhancement of surveillance also included expansion of influenza testing capacity with rRT-PCR to eight states and with immunofluorescence to 30 of 31 Mexico states. As of May 29 , a total of 25,127 specimens had been tested using rRTPCR and, of those tested, 5,337 (21.2\%) had been confirmed as positive for novel influenza $\mathrm{A}(\mathrm{H} 1 \mathrm{~N} 1)$ virus.
Of the 5,337 laboratory-confirmed cases of novel influenza A (H1N1) virus infection, $41.9 \%$ of patients were aged $<15$ years, $32.3 \%$ were aged $15-29$ years, $23.7 \%$ were aged $30-59$ years, and $2.1 \%$ were aged $\geq 60$ years. Among patients with novel influenza $A(\mathrm{H} 1 \mathrm{~N} 1)$ virus infection, $55.7 \%$ of deaths occurred among those aged 30-59 years (Table). Forty-nine percent of patients with confirmed infection were female.

As of May 29, Distrito Federal (Mexico City) had the highest number of laboratory-confirmed novel influenza A (H1N1) cases $(1,804)$ and deaths $(38)$; Mexico State reported 21 deaths (Figure 1). The peak number of confirmed cases (375) had onset of April 27 (Figure 2). As of May 29, all states in Mexico had reported laboratory-confirmed cases of novel influenza A (H1N1) virus.

\section{Control Measures}

On April 24, the federal government of Mexico activated the National Pandemic Preparedness and Response Plan and announced closure of schools in metropolitan Mexico City. Concurrently, the Ministry of Health launched a mass media campaign to promote respiratory hygiene and to alert the public about transmission of influenza. Additional social distancing measures included closure of restaurants and entertainment venues and cancellation of large public gatherings nationwide. To date, Mexico continues enhanced national surveillance and early antiviral treatment to decrease transmission of novel influenza A (H1N1) virus. Respiratory hygiene and hand washing are promoted through television and print media. On May 11, as schools reopened, parents were reminded to keep their children home if they had symptoms of influenza. In addition, a team of teachers and parents screened children at school entrances to determine whether they had fever or respiratory symptoms. The Ministries of

TABLE. Number of suspected, ${ }^{*}$ tested, and laboratory-confirmed novel influenza A (H1N1) cases and deaths - Mexico, March-May 2009

\begin{tabular}{|c|c|c|c|c|c|c|c|c|}
\hline $\begin{array}{l}\text { Age group } \\
\text { (yrs) }\end{array}$ & $\begin{array}{l}\text { No. suspected } \\
\text { cases }\end{array}$ & $\begin{array}{l}\text { No. } \\
\text { tested }\end{array}$ & $\begin{array}{l}\text { No. laboratory- } \\
\text { confirmed } \\
\text { positive }^{\dagger}\end{array}$ & (\%) & $\begin{array}{l}\text { Rate per } 100,000 \\
\text { population }\end{array}$ & $\begin{array}{c}\text { Deaths among } \\
\text { laboratory-confirmed } \\
\text { cases (\% of } \\
\text { confirmed deaths) }\end{array}$ & (\%) & $\begin{array}{c}2009 \\
\text { population }\end{array}$ \\
\hline $0-4$ & 6,428 & 3,520 & 695 & (13.2) & 7.26 & 5 & $(5.2)$ & $9,578,579$ \\
\hline $5-14$ & 7,742 & 4,229 & 1,517 & (28.7) & 7.11 & 7 & (7.2) & $21,327,734$ \\
\hline $15-29$ & 11,568 & 7,591 & 1,704 & (32.3) & 5.83 & 26 & (26.8) & $29,221,168$ \\
\hline $30-59$ & 12,687 & 8,507 & 1,251 & (23.7) & 3.26 & 54 & (55.7) & $38,330,279$ \\
\hline$\geq 60$ & 2,249 & 1,016 & 112 & (2.1) & 1.23 & 5 & $(5.2)$ & $9,092,937$ \\
\hline Age missing & 1,324 & 264 & 58 & - & - & - & - & - \\
\hline Total & 41,998 & 25,127 & 5,337 & $(100.0)$ & 4.96 & 97 & $(100.0)$ & $107,550,697$ \\
\hline
\end{tabular}

* The initial definition of suspected novel influenza A (H1N1) virus infection included any hospitalized patient with severe acute respiratory illness. On May 1 , this definition was expanded to include any person with acute respiratory illness defined as fever and either sore throat or cough. On May 11, the definition of suspected case was changed again to include any person with fever, cough, and headache, plus at least one of the following: rhinorrhea, coryza, arthralgia, myalgia, prostration, sore throat, chest pain, abdominal pain, or nasal congestion. In children aged $<5$ years, irritability replaced headache.

† Reported as of May 29, 2009.

§From Consejo Nacional de Población. Available at http://www.conapo.gob.mx/index.php?option=com_content\&view=article\&id=36\&ltemid=234. 
FIGURE 1. Number of laboratory-confirmed cases of novel influenza A (H1N1) virus infection $(\mathrm{N}=5,337)^{\star}$ and deaths $(\mathrm{N}=97){ }^{\dagger}$ by state and Distrito Federal - Mexico, March-May 2009

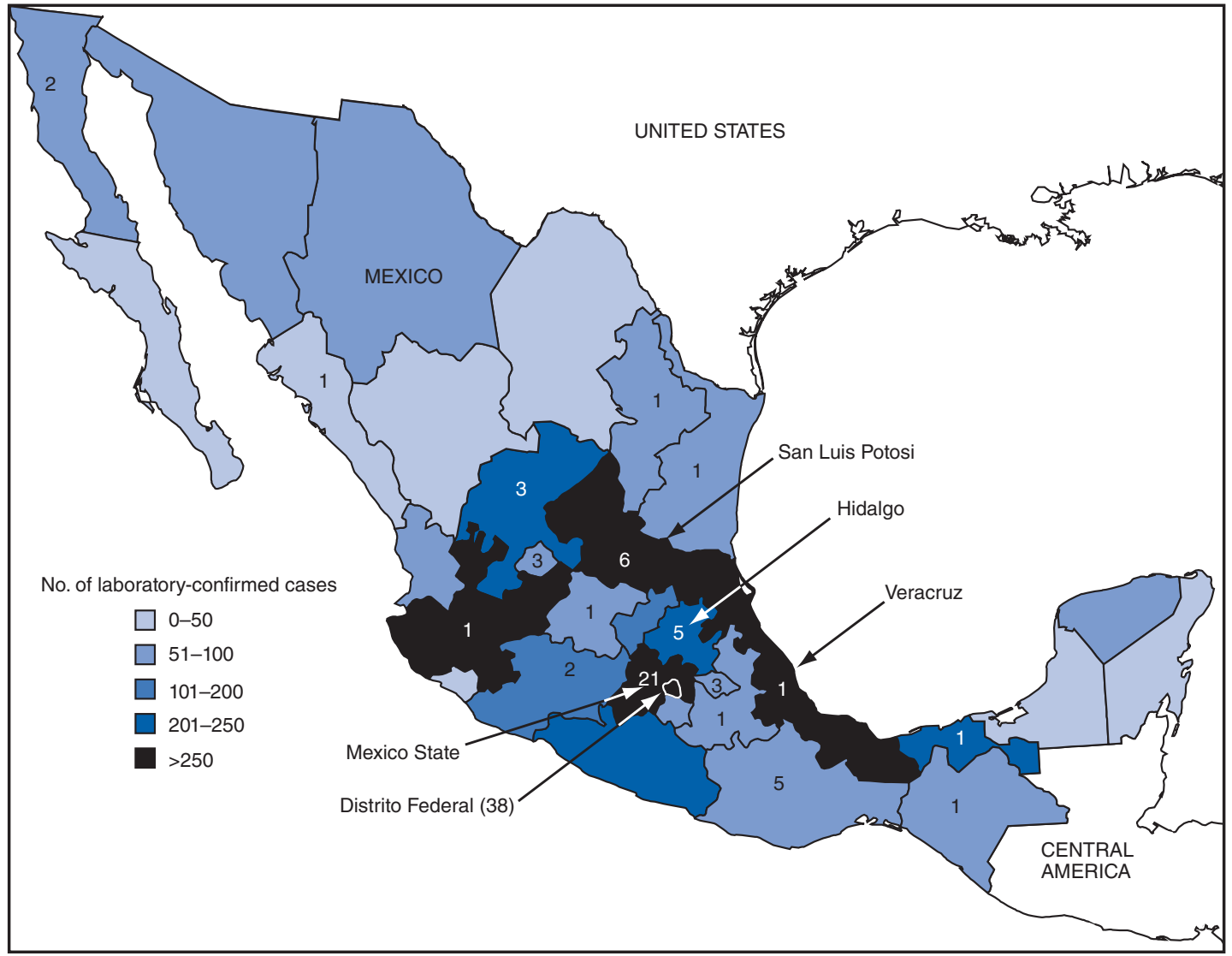

${ }^{*}$ Reported as of May 29, 2009.

$\dagger$ Indicated by numerals.

Education and Health recommended closure of classrooms where two or more children had respiratory symptoms and closure of schools with ill children in two or more classrooms. On the first day of using this strategy, 91,357 children were determined symptomatic. This screening at schools was suspended on May 23. Screening for respiratory illness is ongoing at airports, where passengers complete a brief questionnaire about respiratory symptoms. Symptomatic travelers are asked to delay their journeys and referred for medical evaluation. At Mexico City's International Airport, thermal scanners of body temperatures also are in use.*

Reported by: $J A$ Cordova, $M D, M$ Hernandez, $M D, P h D$, Office of the Secretary of Health; H Lopez-Gatell, MD, PhD, I Bojorquez, MD, PhD, $E$ Palacios, $M D, G$ Rodriguez, $M D, B$ de la Rosa, $M D, R$ Ocampo, $M D$, Directorate General of Epidemiology; C Alpuche, $M D, P h D, R$ Flores, MS, National Institute for Epidemiologic Reference and Diagnostics; JE Hernandez, MD, PhD, National Institute of Public Health, Mexico. Pan American Health Organization, World Health Organization.

\footnotetext{
* Guidance from the Mexico government regarding screening, prevention, and control of novel influenza A (H1N1) virus infection is available at http://portal. salud.gob.mx/contenidos/noticias/influenza/lineamientos.html.
}

J Tustin, MS, K Watkins, MHSc, TL Stuart, PhD, T Kuschak, PhD, $U$ Ströher, PhD, G Soule, B Balcewich, Public Health Agency of Canada. E Azziz-Baumgartner, MD, KLafond, MPH, J Mott, PhD, F Mahoney, MD, T Uyeki, MD, M McCarron, MPH, A Mounts, $M D, M A$ Widdowson, VetMB, $X X u, M D, B$ Shu, MD, S Lindstrom, PhD, A Klimov, PhD, J Katz, PhD, J Winchell, PhD, S Penaranda, N Dybdahl-Sissoko, K Ching, MD, PhD, A Warner, MPA, KEtienne, MPH, National Center for Immunization and Respiratory Diseases; $S$ Waterman, MD, National Center for Preparedness, Detection, and Control of Infectious Diseases; J McAuliffe, MD, S Dowell, MD, Coordinating Office for Global Health; PR Chavez, PhD, EIS Officer, $C D C$.

Editorial Note: Trends in case counts in Mexico suggest that novel influenza A (H1N1) activity is now decreasing, although localized transmission continues to occur. The epidemic curve of laboratory-confirmed cases remains incomplete because of a backlog of untested specimens. However, data regarding suspected cases (3) also indicate a peak in late April, and delays from case identification to reporting have decreased to a median of $<2$ days (Mexico Office of the Secretary of Health, unpublished data, 2009). Taken together, these data suggest that the outbreak likely has moved beyond its peak nationally, 
FIGURE 2. Number $(\mathrm{N}=5,305)$ of laboratory-confirmed cases of novel influenza $A(\mathrm{H} 1 \mathrm{~N} 1)$ virus infection, ${ }^{*}$ by date of illness onset - Mexico, March-May 2009

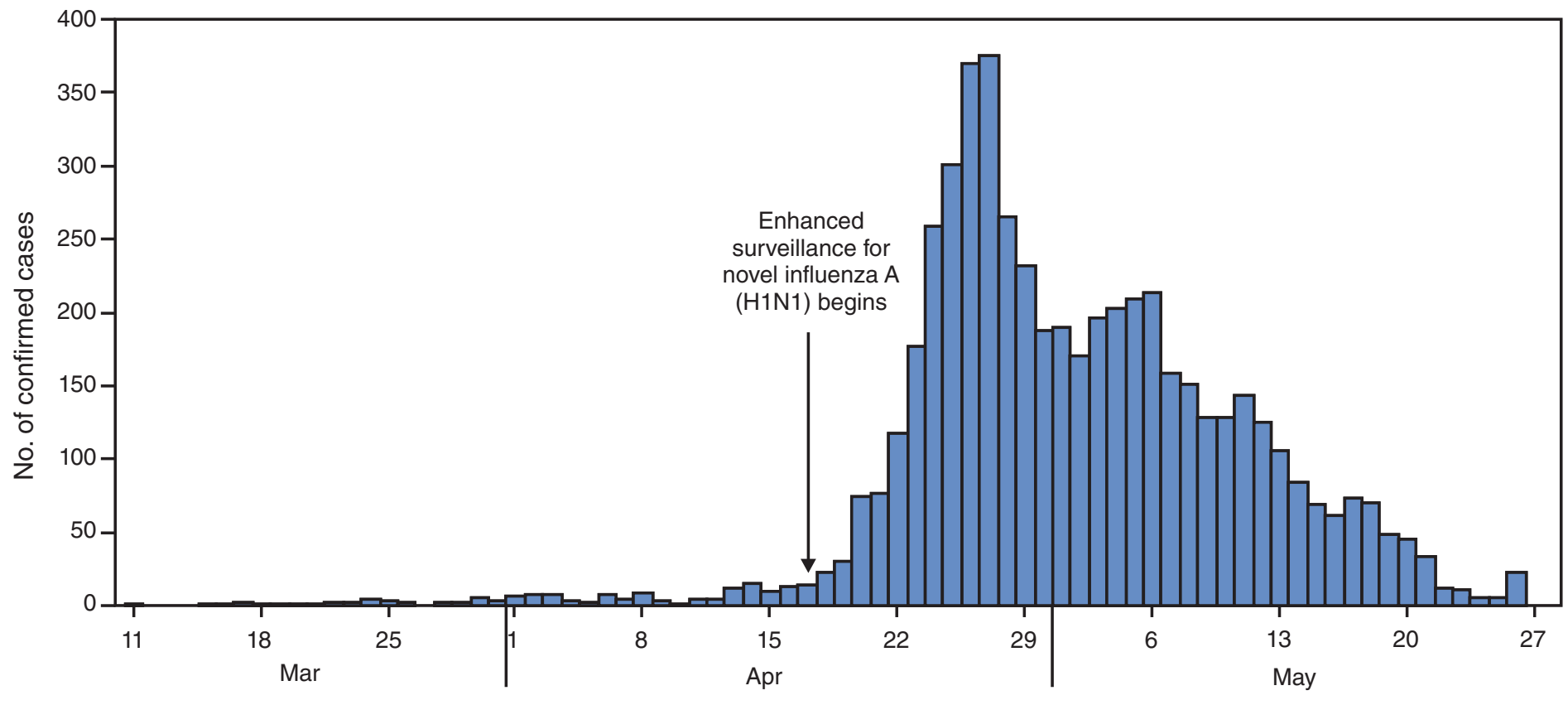

Date of illness onset

* Includes all confirmed cases with onset data reported as of May 29, 2009. Does not reflect all cases because of a backlog of untested specimens.

although a pattern of heterogeneous transmission and focal outbreak activity remains.

Several features of the outbreak in Mexico are consistent with outbreaks of the same novel influenza virus strain circulating in the United States and other countries. These features include person-to-person transmission during a period that is typically the low season for circulation of influenza viruses (4) and an age distribution of laboratory-confirmed cases that includes severe disease and deaths among children and adults in Mexico aged $<60$ years (4). Some deaths have occurred among previously healthy persons (4), and several patients have experienced an aggressive clinical course with severe pneumonia requiring ventilator support and progression to acute respiratory distress syndrome $(2,5,6)$.

A recently reported serologic study suggested that children and younger adults have no or low levels of serum antibody, respectively, that are cross-reactive for the novel influenza $\mathrm{A}$ (H1N1) virus. Approximately one third of U.S. adults aged $>60$ years who were tested had cross-reactive neutralizing antibodies; however, the extent to which such antibody might be protective remains unknown (7). The serologic data, along with the age distribution of illness and clinical severity from the outbreak in Mexico, suggest age $<60$ years as a risk for infection and serious illness from novel A (H1N1) infection.
The current pattern of novel influenza A (H1N1) transmission in the northern hemisphere includes many localized outbreaks, including several among school children (8). This pattern is consistent with influenza outbreaks occasionally reported outside of the usual influenza season (9). However an unprecedented number of such off-season outbreaks are occurring currently. These outbreaks also involve extension into the community, as demonstrated by confirmed illness among travelers with no known epidemiologic link to focal outbreaks. Similar patterns of off-season outbreaks have been observed previously with the emergence and sustained transmission of other novel influenza A virus strains among humans (10).

The recent introduction of novel influenza A (H1N1) into several countries in the southern hemisphere at the beginning of its influenza season and the presumed susceptibility among much of the population to this new virus suggest that this strain might become a dominant circulating virus in the southern hemisphere during the coming months. The government of Mexico continues to coordinate a national response, engage partners, increase surge capacity, and implement mitigation measures to slow the spread of novel influenza A (H1N1). Investigations are ongoing to monitor virus circulation and evaluate mitigation strategies that might help guide prevention and control strategies in Mexico and worldwide. 


\section{References}

1. CDC. Update: swine influenza A (H1N1) infections-California and Texas, April 2009. MMWR 2009;58:435-7.

2. CDC. Outbreak of swine-origin influenza $A(H 1 N 1)$ virus infectionMexico, March-April 2009. MMWR 200958:467-70.

3. Dirección General Adjunta de Epidemiología. Brote de influenza A H1N1 México. Boletín Diario 22 (May 18, 2009).

4. Viboud C, Alonso WJ, Simonsen L. Influenza in tropical regions. PLoS Med 2006;3:e89.

5. World Health Organization. Human infection with new influenza A (H1N1) virus: clinical observations from Mexico and other affected countries, May 2009. Wkly Epidemiol Rec 2009;84:185-9.

6. CDC. Hospitalized patients with novel influenza A (H1N1) virus infection-California, April-May, 2009. MMWR 2009;58:536-41.

7. CDC. Serum cross-reactive antibody response to a novel influenza A $(\mathrm{H} 1 \mathrm{~N} 1)$ virus after vaccination with seasonal influenza vaccine. MMWR 2009;58:521-4

8. CDC. Swine-origin influenza A (H1N1) virus infections in a schoolNew York City, April 2009. MMWR 2009;58:470-2.

9. Kohn MA, Farley TA, Sundin D, Tapia R, McFarland LM, Arden NH. Three summertime outbreaks of influenza type A. J Infect Dis 1995;172:246-9.

10. Taubenberger JK, Morens DM. 1918 influenza: the mother of all pandemics. Emerg Infect Dis 2006;12:15-22.

\section{Incidence and Diagnoses of HIV Infection - Puerto Rico, 2006}

In 2006, 33 U.S. states and five territories had confidential, name-based, human immunodeficiency virus (HIV) infection reporting; among territories, Puerto Rico had the second highest rate of HIV infection (1). To characterize the HIV epidemic in Puerto Rico in 2006 (the year with the most recent available data), the Puerto Rico Department of Health and CDC analyzed data on diagnoses of HIV infection (including infections that occurred in 2006 and in previous years) and used a stratified extrapolation approach developed by CDC (2) to generate HIV incidence estimates (the number of persons newly infected with HIV in 2006). The results indicated that, in 2006, an estimated 1,440 persons aged $\geq 13$ years were newly infected with HIV in Puerto Rico, resulting in an estimated incidence rate of 45.0 cases per 100,000 population, twice the rate for the 50 U.S. states and District of Columbia (DC). Males accounted for $65 \%$ of new HIV infections in Puerto Rico, and 38\% of new HIV infections occurred among persons aged 30-39 years; $39 \%$ of new infections were associated with injection-drug use, and 37\% with high-risk heterosexual contact. The results provide insight into HIV transmission patterns in Puerto Rico that can help guide allocation of resources and the planning, implementation, and evaluation of HIV prevention programs and other services.

Calculation of diagnoses of HIV infection (i.e., HIV diagnosed with or without a concurrent or later acquired immunodeficiency syndrome [AIDS] diagnosis) was based on the 1,021 diagnoses in 2006 among persons aged $\geq 13$ years reported to CDC by the Puerto Rico Department of Health through June 2007. Data were categorized by sex, age group, and mode of HIV transmission. The following hierarchy was used for HIV transmission categories: 1) male-to-male sexual contact, 2) injection-drug use, 3) male-to-male sexual contact and injection-drug use, and 4) high-risk heterosexual contact (i.e., with a sex partner known to have or to be at high risk for HIV infection). The number of reported diagnoses was adjusted for reporting delay using a previously reported procedure (3). In addition, for diagnosed cases missing transmission category (32\%), a multiple imputation procedure was used (4). Percentages were calculated for sex, age group, and transmission categories. HIV diagnosis rates per 100,000 population were calculated for sex and age group using postcensus estimates for 2006 (5).

HIV incidence for Puerto Rico was calculated using the stratified extrapolation approach $(2,6)$. Remnant diagnostic serum specimens from persons aged $\geq 13$ years and diagnosed with HIV infection in 2006 in Puerto Rico were tested with the BED HIV-1 capture enzyme immunoassay (BED) to classify infections as recent or long-standing. In addition to the BED result, the estimation method requires HIV testing history, demographic data, and behavioral information for persons with HIV infection diagnosed in 2006. HIV incidence was calculated from cases based on the 1,021 diagnoses of HIV infection, adjusted to 1,460 for reporting delays in 2006 . Percentages were calculated for sex, age group, and transmission categories. HIV incidence rates per 100,000 population were calculated for sex and age group using official postcensus estimates for 2006 (5).

In 2006, after adjustment for reporting delays, 1,460 persons aged $\geq 13$ years were diagnosed with HIV infection in Puerto Rico (Table 1). Of these, 1,036 (71\%) were males and $424(29 \%)$ were females. By age group, the greatest number of diagnoses of HIV infection occurred among those aged $30-39$ years, followed by those aged $40-49$ years. Among males, the most common mode of HIV transmission was injection-drug use (40\%), followed by male-to-male sexual contact $(30 \%)$. Among females, the most common mode of HIV transmission was high-risk heterosexual contact (73\%), followed by injection-drug use (27\%). The rate of diagnosis of HIV infection in Puerto Rico in 2006 was 45.5 per 100,000 population.

An estimated 1,440 persons ( 45.0 per 100,000 population) were newly infected with HIV in 2006. The HIV incidence rate among males (62.0) was twice that among females (29.8). The highest rate of incident HIV infections, among persons aged 30-39 years (103.6), was 1.7 times that of the age group 
TABLE 1. Adjusted number, ${ }^{*}$ percentage, and rate ${ }^{\dagger}$ of diagnosis of human immunodeficiency virus (HIV) infection ${ }^{\S}$ among persons aged $\geq 13$ years, by selected characteristics - Puerto Rico, 2006

\begin{tabular}{|c|c|c|c|c|}
\hline Characteristic & No. & (\%) & Rate & (95\% Cln) \\
\hline \multicolumn{5}{|l|}{ Sex } \\
\hline Male & 1,036 & (71) & 68.2 & $(58.0-78.5)$ \\
\hline Female & 424 & (29) & 25.1 & $(19.4-30.8)$ \\
\hline \multicolumn{5}{|l|}{ Age group at diagnosis (yrs) } \\
\hline $13-29$ & 298 & (20) & 30.1 & $(22.3-37.8)$ \\
\hline 30-39 & 438 & (30) & 83.1 & $(65.1-101.1)$ \\
\hline $40-49$ & 400 & (27) & 76.6 & $(57.0-96.1)$ \\
\hline$\geq 50$ & 325 & (22) & 27.8 & $(20.1-35.3)$ \\
\hline \multicolumn{5}{|l|}{ Male transmission category } \\
\hline Male-to-male sexual contact ${ }^{\star *}$ & 310 & (30) & - & - \\
\hline Injection-drug use & 419 & $(40)$ & - & - \\
\hline $\begin{array}{l}\text { Male-to-male sexual contact } \\
\text { and injection-drug use }\end{array}$ & 39 & (4) & - & - \\
\hline $\begin{array}{l}\text { High-risk heterosexual } \\
\text { contact }^{\dagger+}\end{array}$ & 267 & (26) & - & - \\
\hline \multicolumn{5}{|l|}{$\begin{array}{l}\text { Female transmission } \\
\text { category }\end{array}$} \\
\hline Injection-drug use & 114 & (27) & - & - \\
\hline $\begin{array}{l}\text { High-risk heterosexual } \\
\text { contact }\end{array}$ & 310 & (73) & - & - \\
\hline Total & $1,460^{\S \S}$ & $(100)^{\star \star \star}$ & 45.5 & $(39.8-51.2)$ \\
\hline
\end{tabular}

* Numbers result from adjustments of reported case counts for reporting delay. Missing information on transmission category was imputed.

† Per 100,000 population; postcensus estimates from the U.S. Census. Rates for transmission category subgroups were not calculated because population denominators were unavailable.

$\S$ Includes 1) persons with a diagnosis of HIV infection but not acquired immunodeficiency syndrome (AIDS), 2) persons with a diagnosis of HIV infection and a later diagnosis of AIDS in 2006, or 3) persons with concurrent diagnoses of HIV infection and AIDS.

" Confidence interval.

** Because of small numbers, persons with both male-to-male sexual contact and injection-drug use were included in this category.

${ }^{\text {t† }}$ Heterosexual contact with a person known to have, or to be at high risk for HIV infection.

$\S \S$ Because column totals were calculated independently of subpopulation values, the subpopulation values might not sum to the total.

*** Percentages might not sum to $100 \%$ because of rounding.

with the next highest rate (40-49 years [59.3]). The mode of transmission with the greatest number of new HIV infections was injection-drug use (39\%), followed by high-risk heterosexual contact (37\%) and male-to-male sexual contact (24\%) (Table 2).

Reported by: S Miranda, MPH, B Lopez, MS, EJ García-Rivera, $M D$, Puerto Rico Dept of Health. M Rangel, MD, PhD, Public Health Strategic Health Care Group, Dept of Veterans Affairs. AL Hernandez, $M D, L$ Espinoza, DDS, $Q$ An, $M S, R$ Song, PhD, $R$ Zhang, MS, $Z$ Myles, MPH, Div of HIVIAIDS Prevention, National Center for HIVIAIDS, Viral Hepatitis, STD, and TB Prevention, CDC.

Editorial Note: These estimates of HIV incidence in Puerto Rico in 2006 reveal important differences between HIV epidemiology in Puerto Rico and the 50 U.S. states and DC. The overall HIV incidence rate in Puerto Rico in 2006 (45.0 per 100,000 population) was twice the estimated U.S. rate (22.8) and 1.5 times the estimated rate for Hispanics in the United
TABLE 2. Estimated number, ${ }^{\star}$ percentage, and rate ${ }^{\dagger}$ of new human immunodeficiency virus (HIV) infections among persons aged $\geq 13$ years, by selected characteristics - Puerto Rico, 2006

\begin{tabular}{|c|c|c|c|c|c|}
\hline Characteristic & No.§ & (95\% Cli) & $\%$ & Rate & $(95 \% \mathrm{Cl})$ \\
\hline \multicolumn{6}{|l|}{$\overline{\text { Sex }}$} \\
\hline Male & 940 & $(650-1,240)$ & 65 & 62.0 & $(42.5-81.4)$ \\
\hline Female & 500 & (320-700) & 35 & 29.8 & $(18.8-40.8)$ \\
\hline \multicolumn{6}{|l|}{ Age group (yrs) } \\
\hline $13-29$ & 390 & $(230-540)$ & 27 & 39.0 & $(23-54.8)$ \\
\hline 30-39 & 540 & $(340-750)$ & 38 & 103.6 & $(64.2-143.1)$ \\
\hline $40-49$ & 310 & $(140-480)$ & 21 & 59.3 & $(26.1-92.5)$ \\
\hline$\geq 50$ & 200 & $(70-340)$ & 14 & 17.4 & $(6.1-28.8)$ \\
\hline \multicolumn{6}{|l|}{$\begin{array}{l}\text { Transmission } \\
\text { category }\end{array}$} \\
\hline $\begin{array}{l}\text { Male-to-male sexual } \\
\text { contact }^{\star \star}\end{array}$ & 350 & $(190-520)$ & 24 & - & - \\
\hline Injection-drug use & 560 & (340-790) & 39 & - & - \\
\hline $\begin{array}{l}\text { High-risk heterosexual } \\
\text { contact }{ }^{\dagger \dagger}\end{array}$ & 530 & $(300-770)$ & 37 & - & - \\
\hline Total & 1,440 & $(1,060-1,830)$ & 100 & 45.0 & $(33.1-57.0)$ \\
\hline
\end{tabular}

* Numbers are estimates, resulting from adjustments of reported case counts for reporting delay. Missing information on transmission category was imputed.

${ }^{\dagger}$ Per 100,000 population; postcensus estimates from the U.S. Census. Rates for transmission category subgroups were not calculated because population denominators were unavailable.

$\S$ Rounded to tens.

" Confidence interval.

** Because of small numbers, persons with both male-to-male sexual contact and injection-drug use were included in this category.

${ }^{\dagger \dagger}$ Heterosexual contact with a person known to have, or to be at high risk for HIV infection.

States (29.4). The incidence rate among males in Puerto Rico (62.0) was 1.8 times the rate among U.S. males (34.3) and 1.4 times the rate among U.S. Hispanic males (43.1). The incidence rate among females in Puerto Rico (29.8) was 2.5 times the rate among U.S. females (11.9) and 2.0 times the rate in U.S. Hispanic females (14.4) $(6,7)$. However, comparisons between the rates for Puerto Rico and the rates for Hispanics in the United States should consider differences in the two populations. Hispanics in the United States include persons who are U.S. born and those of diverse national origin whose behavioral characteristics might differ from Hispanics in Puerto Rico (8). In addition, the number of diagnoses of HIV infection generally is higher in metropolitan areas, and population density in Puerto Rico (1,112 persons per square mile) is 14 times that of the United States (79.6 persons) $(1,6,7,9)$.

Injection-drug use continues to be the most common mode of HIV transmission in Puerto Rico, whereas most new HIV infections in the 50 U.S. states and DC are attributed to maleto-male sexual contact $(1,6-8)$. Previous reports have indicated greater prevalence of injection-drug use and high-risk health behaviors related to injection-drug use (e.g., frequency of injecting and sharing syringes and other drug paraphernalia) in Puerto Rico than in the United States (8). 
In 2006, most new HIV infections in the United States, including among Hispanics, occurred in persons aged 13-29 years ( 7 ). In contrast, most new HIV infections in Puerto Rico occurred among persons aged 30-39 years. This age group had the highest rates of new HIV infection in both Puerto Rico and the United States; however, the incidence rate in Puerto Rico (103.6 per 100,000 population) was 2.4 times the rate in the United States (42.6) (6). One possible explanation for the higher rates in this age group in Puerto Rico might be related to injection-drug use. Persons commonly begin using noninjection drugs and progress to injection-drug use. However, further investigation is needed to test that hypothesis and fully understand the reasons for difference in the rates.

The findings in this report are subject to at least two limitations. The classification of cases reported without a risk factor for transmission was based on a model incorporating random variations to impute missing values (4). Although multiple imputation procedures are designed to maintain associations within the data, the degree of uncertainty introduced by this imputation procedure is unknown. Second, the stratified extrapolation approach to HIV incidence estimation is based on several key assumptions, including that information on previous tests and BED results were missing at random, that testing behavior has not changed substantially over several years, that testing and infection are independent, and that information on previous testing is accurate (2). Concerns have been raised about the accuracy of the BED test, which appeared to result in overestimation of recent HIV infections in Africa and Thailand (10). The implications of these assumptions on incidence estimation have been discussed extensively $(2,6)$

The HIV epidemic in Puerto Rico is notably different from the epidemic in the United States overall and among Hispanics in the United States $(1,6-8)$. CDC supports prevention efforts that target populations at greatest risk in Puerto Rico, including injection-drug users, women who have high-risk heterosexual contact, men who engage in male-to-male sexual contact, and youths. To address transmission of HIV infection among injection-drug users, the Puerto Rico Department of Health provides syringe exchange programs and rapid HIV testing, has implemented policies to allow pharmacies to sell syringes without medical prescription, and provides drug rehabilitation services throughout the country. The findings in this report help describe the HIV epidemic in Puerto Rico and can help guide future allocation of resources and planning, implementation, and evaluation of HIV prevention programs and services.

\section{Acknowledgments}

This report is based, in part, on contributions by AL Rivera, I Santiago, V Aviles, MS, M Cruz, MS, B Resto, Y Ayala, and
MR Irizarry, Puerto Rico Dept of Health; J Prejean, Div of HIV/ AIDS Prevention Surveillance and Epidemiology, M Ayala-Perales, and J Andia, Div of HIV/AIDS Prevention Intervention Research and Support, National Center for HIV/AIDS, Viral Hepatitis, STD, and TB Prevention, CDC.

\section{References}

1. CDC. HIV/AIDS surveillance report, 2006. Atlanta, GA: US Department of Health and Human Services, CDC; 2008. Report no. 18. Available at http://www.cdc.gov/hiv/topics/surveillance/resources/ reports/2006report/default.htm.

2. Karon JM, Song R, Kaplan E, Brookmeyer R, Kaplan EH, Hall HI. Estimating HIV incidence in the United States from HIV/ AIDS surveillance data and biomarker HIV test results. Stat Med 2008;27:4617-33.

3. Green TA. Using surveillance data to monitor trends in the AIDS epidemic. Stat Med 1998;17:143-54.

4. Harrison KM, Kajese T, Hall HI, Song R. Risk factor redistribution of the national HIV/AIDS surveillance data: an alternative approach. Public Health Rep 2008;123:618-26.

5. CDC. Bridged-race Vintage 2006 postcensal population estimates for July 1, 2000-July 1, 2006, by year, county, single-year of age, bridgedrace, Hispanic origin, and sex. Available at http://www.cdc.gov/nchs/ about/major/dvs/popbridge/datadoc.htm\#vintage2006.

6. Hall HI, Song R, Rhodes P, et al; HIV Incidence Surveillance Group. Estimation of HIV incidence in the United States. JAMA 2008;300:520-9.

7. CDC. Subpopulation estimates from the HIV incidence surveillance system-United States, 2006. MMWR 2008;57:985-9.

8. Espinoza L, Hall HI, Selik RM, Hu X. Characteristics of HIV infection among Hispanics, United States 2003-2006. J Acquir Immune Defic Syndr 2008;49:94-101.

9. US Census Bureau. United States-States; and Puerto Rico. GCT-PH1. Population, housing units, area, and density: 2000 data set. Census 2000 summary file 1 (SF 1) 100-percent data. Available at http://factfinder. census.gov.

10. UNAIDS. Statement on the use of the BED assay for the estimation of HIV-1 incidence for surveillance or epidemic monitoring: report of a meeting of the UNAIDS Reference Group for Estimates, Modeling and Projections. Athens, Greece: UNAIDS; 2005. Available at http:// www.epidem.org/publications/bed\%20statement.pdf.

\section{Impact of New WHO Growth Standards on the Prevalence of Acute Malnutrition and Operations of Feeding Programs - Darfur, Sudan, 2005-2007}

Acute malnutrition among children aged 6-59 months is a key indicator routinely used for describing the presence and magnitude of humanitarian emergencies. In the past, the prevalence of acute malnutrition and admissions to feeding programs has been determined using the growth reference developed by the World Health Organization (WHO), CDC, and the National Center for Health Statistics (NCHS). In 2006, WHO released new international growth standards and 
recommended their use in all nutrition programs. To evaluate the impact of transitioning to the new standards, CDC analyzed anthropometric data for children aged 6-59 months from Darfur, Sudan, collected during 2005-2007. This report describes the results of that analysis, which indicated that use of the new standards would have increased the prevalence of global acute malnutrition on average by $14 \%$ and would have increased the prevalence of severe acute malnutrition on average by $100 \%$. Admissions to feeding programs would have increased by $56 \%$ for moderately malnourished children and by $260 \%$ for severely malnourished children. For programs in Darfur, this would have resulted in approximately 23,200 more children eligible for therapeutic feeding programs. For the immediate future, the prevalence of acute malnutrition in children should be reported using both the old $\mathrm{WHO} /$ $\mathrm{CDC} / \mathrm{NCHS}$ reference and the new WHO standards. More research is needed to better ascertain the validity of the admission criteria based on the new WHO standards in predicting malnutrition-related morbidity and mortality.

Historically, measures of acute malnutrition have been based on the $\mathrm{WHO} / \mathrm{CDC} / \mathrm{NCHS}$ growth reference (1). This reference is a normalized version of the 1977 NCHS reference (2). The NCHS reference is based on data from predominantly formula-fed children collected in the United States during the 1960 s and 1970s. However, at least one report has indicated a need for more internationally representative, up-to-date growth standards based on predominantly breastfed children (3). Therefore, in 2006, WHO developed new growth standards using data collected during 1997-2003 from predominantly breastfed children living in favorable conditions from sites in six regions of the world $(4,5)$. The WHO growth standards are considered preferable because they represent how healthy children should grow, whereas the WHO/CDC/NCHS reference only represents how children grew in a specific place and time (4).

To describe acute malnutrition at the population level, two prevalence indicators are normally reported: global acute malnutrition (GAM) and severe acute malnutrition (SAM) (6). GAM and SAM are the principal indicators reported in nutrition surveys and are used to compare population prevalence of acute malnutrition across time and geographic areas. Prevalences of GAM and SAM are based on the proportion of children aged 6-59 months whose weight and height categorize them below a certain Z-score (Table 1). A Z-score is the number of standard deviations from the weight of an individual child to the reference mean weight, for a given height and sex.

To determine the need for admission to a selective feeding program, children are classified as being moderately malnourished (eligible for supplementary feeding programs) or severely malnourished (eligible for therapeutic feeding programs). In contrast to population prevalence measures (GAM and SAM), this classification has been based previously on the percentage of the median of the WHO/CDC/NCHS growth reference, as opposed to Z-scores (Table 1). Percentage median is the ratio of the weight of an individual child to the reference mean weight, for a given height and sex. The new WHO guidelines recommend that Z-scores be used not only for measures of population prevalence but also as admission criteria for feeding programs, eliminating use of the percentage median (7), because $\mathrm{Z}$-scores more accurately take into account the distribution of the anthropometric measures within the population. These standards have been endorsed by other United Nations agencies and international health and nutrition bodies (e.g., the United Nations Standing Committee on Nutrition and the International Pediatric Association) and has been adopted in approximately 90 countries ( 7 ).

CDC analyzed data obtained from three annual crosssectional nutritional surveys conducted during 2005-2007 in Darfur, Sudan, by the United Nations Children's Fund (UNICEF), the World Food Programme, and CDC. All three surveys obtained anthropometric data from children aged 6-59 months from each of Darfur's three states. Anthropometry scores for each child, including the WHO/CDC/NCHS percentage median, WHO/CDC/NCHS Z-score, and WHO Z-score, were generated.* Records with missing critical data and extreme outliers (e.g., those with Z-scores greater than \pm 4 from the observed mean Z-score) were excluded from analysis.

GAM, SAM, and admission eligibility for moderate and severe acute malnutrition based on the WHO/CDC/NCHS and WHO standards were defined (Table 1) (8). The prevalences of GAM and SAM were calculated for each annual survey using $\mathrm{WHO} / \mathrm{CDC} / \mathrm{NCHS} \mathrm{Z}$-scores versus $\mathrm{WHO}$ $\mathrm{Z}$-scores, and compared by calculating the relative percentage change for years 2005, 2006, and 2007. To estimate the effects on admissions into feeding programs, the proportions of moderate and severe malnutrition cases were calculated for each annual survey using WHO/CDC/NCHS percentage median versus $\mathrm{WHO} Z$-scores, and compared by calculating the relative percentage change for each year of data. The relative percentage change for combined data from all three years for all measures was calculated. Finally, based on projections of the percentage and numbers of children with SAM, the effects on costs for operating therapeutic feeding programs in Darfur were estimated. A full treatment course for the severely malnourished was assumed to cost \$203 (95\% confidence interval $[\mathrm{CI}]=$ \$139-\$274) (9).

\footnotetext{
* Scores generated using emergency nutrition assessment software (ENA for SMART), available at http://www.nutrisurvey.de/ena/ena.html.
} 
TABLE 1. World Health Organization/CDC/National Center for Health Statistics (WHO/CDC/NCHS) and WHO definitions of acute malnutrition using weight-for-height and/or edema in children aged 6-59 months

\begin{tabular}{lll}
\hline Categories & \multicolumn{1}{c}{ WHO/CDC/NCHS } & WHO \\
\hline $\begin{array}{l}\text { Prevalence } \\
\text { Global acute malnutrition }\end{array}$ & Z-score ${ }^{*}<-2$ or bilateral edema & Z-score $<-2$ or bilateral edema \\
$\begin{array}{l}\text { Severe acute malnutrition } \\
\begin{array}{l}\text { Feeding program enrollment } \\
\text { Moderate acute malnutrition }\end{array}\end{array}$ & Z-score $<-3$ or bilateral edema & Z-score $<-3$ or bilateral edema \\
Severe acute malnutrition & $<80 \%$ to $\geq 70 \%$ percentage median ${ }^{\dagger}$ without edema & Z-score $\geq-3$ and $<-2$ \\
\hline
\end{tabular}

${ }^{*} \mathrm{~A}$ Z-score is the number of standard deviations from the weight of an individual child to the reference mean weight, for a given height and sex.

$\dagger$ Percentage median is the ratio of the weight of an individual child to the reference mean weight, for a given height and sex.

When comparing the prevalence of GAM using WHO $\mathrm{Z}$-scores versus $\mathrm{WHO} / \mathrm{CDC} / \mathrm{NCHS} \mathrm{Z}$-scores, an overall relative increase of $14 \%$ was observed (Table 2). For SAM, using WHO growth standards resulted in an overall relative increase of $100 \%$ compared with WHO/CDC/NCHS-based results. When comparing estimates of eligibility for feeding program enrollment for moderately malnourished children, using WHO Z-scores compared with WHO/CDC/NCHS percentage median indicated an overall relative increase of $56 \%$ (Table 3). For severely malnourished children, using WHO Z-scores showed an overall relative increase of $260 \%$ compared with $\mathrm{WHO} / \mathrm{CDC} / \mathrm{NCHS}$ percentage median.

Analysis of the 2007 data indicated that, by converting from $\mathrm{WHO} / \mathrm{CDC} / \mathrm{NCHS}$ reference to $\mathrm{WHO}$ standards, the projected number of severely malnourished children would increase from approximately 6,800 to 30,000 . This translates to an increase in operating expenses for therapeutic feeding programs by an estimated $\$ 4.7$ million $(\mathrm{CI}=\$ 3.2-\$ 6.3$ million). This estimate does not take into account the additional cost for treating moderately malnourished children.

Reported by: O Bilukha, MD, PhD, L Talley, MPH, National Center for Environmental Health; C Howard, MD, EIS Officer, CDC.

Editorial Note: Results of this study demonstrate that transitioning to the new WHO growth standards will have substantial effects on the population prevalence of GAM and SAM, admissions to feeding programs, and costs of program operations. This analysis shows moderate increases in GAM and substantial increases in SAM at levels similar to a previously published report based on displaced populations (10). Also, based on these estimates, three to four times as many children would be eligible for admission into therapeutic feeding programs.

The findings in this report are subject to at least one limitation. Errors might have occurred during field data collection, which can be challenging in austere settings such as Darfur, where access to the survey population often is limited because of a lack of security and a lack of qualified survey personnel.

CDC recommends that nutrition survey reports on acute malnutrition should, for the immediate future, use both the WHO/CDC/NCHS reference and the WHO standards. Considering the programmatic importance of comparing yearto-year data, if prevalences based only on the WHO growth standards were reported, they could not be compared easily with levels reported from previous years based on WHO/ $\mathrm{CDC} / \mathrm{NCHS}$ reference. For example, reporting a SAM level of $4.4 \%$ using the WHO standard, without explaining that it corresponds to a SAM level of $1.8 \%$ based on the WHO/ $\mathrm{CDC} / \mathrm{NCHS}$ reference, might be somewhat misleading. The guidelines that designate levels of GAM and SAM at which large-scale nutritional interventions are indicated should be updated to reflect expected changes in magnitude of acute malnutrition observed with the new standards. Finally, more

TABLE 2. Prevalence of global acute malnutrition (GAM) and severe acute malnutrition (SAM) based on World Health Organization/CDC/National Center for Health Statistics (WHO/CDC/NCHS) Z-score* and WHO Z-score growth standards, by year Darfur, Sudan, 2005-2007

\begin{tabular}{|c|c|c|c|c|c|c|}
\hline \multirow[b]{2}{*}{ Condition } & \multirow[b]{2}{*}{ Year } & \multicolumn{2}{|c|}{ WHO/CDC/NCHS Z-score } & \multicolumn{2}{|c|}{ WHO Z-score } & \multirow[b]{2}{*}{ Relative change (\%) } \\
\hline & & Prevalence (\%) & $\left(95 \% \mathrm{CI}^{\dagger}\right)$ & Prevalence (\%) & $(95 \% \mathrm{Cl})$ & \\
\hline \multirow[t]{4}{*}{$\overline{\text { GAM }}$} & $2005(N=1,898)$ & 12.1 & $(10.3-13.8)$ & 14.1 & $(12.3-16.1)$ & 17 \\
\hline & $2006(N=2,171)$ & 12.9 & $(11.1-14.8)$ & 15.3 & $(13.4-17.2)$ & 19 \\
\hline & $2007(\mathrm{~N}=2,206)$ & 16.1 & $(14.8-18.2)$ & 17.2 & $(15.1-19.3)$ & 7 \\
\hline & All years combined $(\mathrm{N}=6,275)$ & 13.7 & $(12.6-14.9)$ & 15.6 & $(14.4-16.7)$ & 14 \\
\hline \multirow[t]{4}{*}{ SAM } & $2005(N=1,898)$ & 1.5 & $(0.9-2.0)$ & 3.0 & $(2.2-3.9)$ & 100 \\
\hline & $2006(N=2,171)$ & 1.9 & $(1.3-2.5)$ & 3.1 & $(2.3-3.9)$ & 63 \\
\hline & $2007(N=2,206)$ & 1.8 & $(1.2-2.5)$ & 4.4 & $(3.4-5.5)$ & 144 \\
\hline & All years combined $(\mathrm{N}=6,275)$ & 1.8 & $(1.4-2.1)$ & 3.6 & (3.0-4.1) & 100 \\
\hline
\end{tabular}

${ }^{*} \mathrm{~A}$ Z-score is the number of standard deviations from the weight of an individual child to the reference mean weight, for a given height and sex.

† Confidence interval. 
TABLE 3. Prevalence of moderate and severe acute malnutrition based on World Health Organization/CDC/National Center for Health Statistics (WHO/CDC/NCHS) percentage median* $(\% \mathrm{M})$ and WHO Z-score ${ }^{\dagger}$ growth standards, by year - Darfur, Sudan, 2005-2007

\begin{tabular}{|c|c|c|c|c|c|c|}
\hline \multirow[b]{2}{*}{ Condition } & \multirow[b]{2}{*}{ Year } & \multicolumn{2}{|c|}{ WHO/CDC/NCHS (\% M) } & \multicolumn{2}{|c|}{ WHO (Z-score) } & \multirow{2}{*}{$\begin{array}{l}\text { Relative change } \\
(\%)\end{array}$} \\
\hline & & Prevalence (\%) & $(95 \% \mathrm{Cl})$ & Prevalence (\%) & $(95 \% \mathrm{Cl})$ & \\
\hline $\begin{array}{l}\text { Moderate malnutrition } \\
\text { (supplementary feeding) }\end{array}$ & $\begin{array}{l}2005(N=1,898) \\
2006(N=2,171) \\
2007(N=2,206) \\
\text { All years combined }(N=6,275)\end{array}$ & $\begin{array}{r}6.7 \\
7.4 \\
8.9 \\
7.7\end{array}$ & $\begin{array}{r}(5.3-8.1) \\
(5.9-8.8) \\
(7.3-10.5) \\
(6.9-8.5)\end{array}$ & $\begin{array}{r}11.2 \\
12.2 \\
12.7 \\
12.0\end{array}$ & $\begin{array}{r}(9.2-13.1) \\
(10.2-14.1) \\
(10.6-14.8) \\
(11.0-13.0)\end{array}$ & $\begin{array}{l}67 \\
65 \\
43 \\
56\end{array}$ \\
\hline $\begin{array}{l}\text { Severe malnutrition } \\
\text { (therapeutic feeding) }\end{array}$ & $\begin{array}{l}2005(N=1,898) \\
2006(N=2,171) \\
2007(N=2,206) \\
\text { All years combined }(N=\mathbf{6 , 2 7 5})\end{array}$ & $\begin{array}{l}1.0 \\
1.0 \\
1.0 \\
1.0\end{array}$ & $\begin{array}{l}(0.5-1.4) \\
(0.5-1.3) \\
(0.5-1.4) \\
(0.7-1.2)\end{array}$ & $\begin{array}{l}3.0 \\
3.1 \\
4.4 \\
3.6\end{array}$ & $\begin{array}{l}(2.2-3.9) \\
(2.3-3.9) \\
(3.4-5.5) \\
(3.0-4.1)\end{array}$ & $\begin{array}{l}200 \\
210 \\
341 \\
\mathbf{2 6 0}\end{array}$ \\
\hline
\end{tabular}

* Percentage median is the ratio of the weight of an individual child to the reference mean weight, for a given height and sex.

† A Z-score is the number of standard deviations from the weight of an individual child to the reference mean weight, for a given height and sex.

$\S$ Confidence interval.

research might be needed to determine what Z-score cutoffs are appropriate for classifying individual children as having moderate or severe acute malnutrition. The focus should be on determining cutoffs that are most sensitive and specific for malnutrition-related morbidity and mortality. If the currently recommended WHO Z-score cutoffs for admission into feeding programs are applied, both the funding and the size of the feeding programs (accounting for the number of trained staff required, infrastructure, and feeding commodities) will have to increase several-fold. If the agencies are not prepared to immediately substantially increase their feeding program funding and operations in parallel with a substantial increase in the number of children eligible for admission into feeding programs, the quality of care might be compromised and resources diluted.

WHO recommends that the new growth standards be used globally in all feeding programs for acutely malnourished children. The substantial increase in patient load expected with the adoption of the new standards underscores the need to monitor how rapidly international relief agencies and ministries of health are able to adapt in terms of enrollment rates, personnel resources, and financial expenditures.

\section{References}

1. Dibley MJ, Goldsby JB, Staehling NW, Trowbridge FL. Development of normalized curves for the international growth reference: historical and technical considerations. Am J Clin Nutr 1987;46:736-48.

2. Hamill PV, Drizd TA, Johnson CL, Reed RB, Roche AF, Moore WM. Physical growth: National Center for Health Statistics percentiles. Am J Clin Nutr 1979;32:607-29.

3. World Health Organization. An evaluation of infant growth. WHO Working Group on Infant Growth. World Health Organization: Geneva, Switzerland; 1994.

4. World Health Organization. WHO child growth standards: length/ height-for-age, weight-for-age, weight-for-length, weight-for-height and body mass index-for-age: methods and development. Geneva, Switzerland: World Health Organization; 2006.
5. de Onis M, Garza C, Onyango AW, Martorell R, eds. WHO child growth standards. Acta Paediatrica 2006;450(Suppl):1-101.

6. World Health Organization. Physical status: the use and interpretation of anthropometry. World Health Organ Tech Report Ser 1995;854.

7. World Health Organization and UNICEF. WHO child growth standards and the identification of severe acute malnutrition in infants and children. A joint statement by the World Health Organization and the United Nations Children's Fund. Geneva, Switzerland: World Health Organization and UNICEF; 2009.

8. World Health Organization. The management of nutrition in major emergencies. Geneva, Switzerland: World Health Organization; 2000.

9. Bachmann M. Cost effectiveness of community-based therapeutic care for children with severe acute malnutrition in Zambia: decision tree model. Cost Eff Resour Alloc 2009;7:2.

10. Seal A, Kerac M. Operational implications of using 2006 World Health Organization growth standards in nutrition programmes: secondary data analysis. BMJ 2007;334:733.

\section{Notice to Readers}

\section{Discontinuation of Paper Copies of MMWR Continuing Education Activities}

Effective July 6, 2009, MMWR will discontinue publishing continuing education (CE) activities in hard-copy format. $M M W R$ will continue to offer CE electronically on the $M M W R$ CE website at http://www.cdc.gov/mmwr/cme/conted.html. MMWR offers CE credits for the following: Continuing Medical Education (CME), Continuing Medical Education for Nonphysicians (CME-NP), Continuing Education Unit (CEU), Continuing Nursing Education (CNE), Certified Health Education Specialist (CHES), Continuing Pharmacy Education (CPE), and Continuing Veterinary Education (CVE). No fees are charged for participating in the CE activities. Questions and comments should be submitted to the MMWR CE mailbox at mmwrce@cdc.gov. 
TABLE I. Provisional cases of infrequently reported notifiable diseases $(<1,000$ cases reported during the preceding year) - United States, week ending May 30, 2009 (21st week)*

\begin{tabular}{|c|c|c|c|c|c|c|c|c|c|}
\hline \multirow[b]{2}{*}{ Disease } & \multirow{2}{*}{$\begin{array}{c}\text { Current } \\
\text { week }\end{array}$} & \multirow{2}{*}{$\begin{array}{l}\text { Cum } \\
2009\end{array}$} & \multirow{2}{*}{$\begin{array}{c}\text { 5-year } \\
\text { weekly } \\
\text { average }^{\dagger}\end{array}$} & \multicolumn{5}{|c|}{$\begin{array}{l}\text { Total cases reported } \\
\text { for previous years }\end{array}$} & \multirow{2}{*}{$\begin{array}{l}\text { States reporting cases } \\
\text { during current week (No.) }\end{array}$} \\
\hline & & & & 2008 & 2007 & 2006 & 2005 & 2004 & \\
\hline Anthrax & - & - & - & - & 1 & 1 & - & - & \\
\hline \multicolumn{10}{|l|}{ Botulism: } \\
\hline foodborne & - & 8 & 1 & 17 & 32 & 20 & 19 & 16 & \\
\hline infant & - & 20 & 2 & 109 & 85 & 97 & 85 & 87 & \\
\hline other (wound and unspecified) & - & 11 & 0 & 19 & 27 & 48 & 31 & 30 & \\
\hline Brucellosis & 1 & 35 & 2 & 77 & 131 & 121 & 120 & 114 & $\mathrm{FL}(1)$ \\
\hline Chancroid & - & 17 & 0 & 25 & 23 & 33 & 17 & 30 & \\
\hline Cholera & - & 2 & 0 & 3 & 7 & 9 & 8 & 6 & \\
\hline Cyclosporiasis $\S$ & 1 & 32 & 16 & 139 & 93 & 137 & 543 & 160 & $\mathrm{FL}(1)$ \\
\hline \multirow{2}{*}{\multicolumn{10}{|c|}{ Domestic arboviral diseases§,ף: }} \\
\hline & & & & & & & & & \\
\hline California serogroup & - & - & 0 & 62 & 55 & 67 & 80 & 112 & \\
\hline eastern equine & - & - & - & 4 & 4 & 8 & 21 & 6 & \\
\hline Powassan & - & - & 0 & 2 & 7 & 1 & 1 & 1 & \\
\hline St. Louis & - & - & 0 & 13 & 9 & 10 & 13 & 12 & \\
\hline western equine & - & - & - & - & - & - & - & - & \\
\hline \multicolumn{10}{|l|}{ Ehrlichiosis/Anaplasmosis§, ,**: } \\
\hline Ehrlichia chaffeensis & 7 & 75 & 11 & 1,098 & 828 & 578 & 506 & 338 & $\mathrm{MO}(3), \mathrm{MD}(1), \mathrm{GA}(1), \mathrm{FL}(1), \mathrm{TN}(1)$ \\
\hline Ehrlichia ewingii & - & - & - & 9 & - & - & - & - & \\
\hline Anaplasma phagocytophilum & 2 & 33 & 10 & 739 & 834 & 646 & 786 & 537 & NY (2) \\
\hline undetermined & - & 15 & 5 & 158 & 337 & 231 & 112 & 59 & \\
\hline \multicolumn{10}{|l|}{$\begin{array}{l}\text { Haemophilus influenzae, }{ }^{\dagger \dagger} \\
\text { invasive disease (age }<5 \text { yrs): }\end{array}$} \\
\hline serotype b & 1 & 12 & 0 & 28 & 22 & 29 & 9 & 19 & $\mathrm{CO}(1)$ \\
\hline nonserotype b & 1 & 81 & 3 & 238 & 199 & 175 & 135 & 135 & $A Z(1)$ \\
\hline unknown serotype & 4 & 88 & 4 & 166 & 180 & 179 & 217 & 177 & VT (1), NYC (1), OH (2) \\
\hline Hansen disease§ & 1 & 22 & 2 & 80 & 101 & 66 & 87 & 105 & $\mathrm{OH}(1)$ \\
\hline Hantavirus pulmonary syndrome $§$ & - & 3 & 1 & 18 & 32 & 40 & 26 & 24 & \\
\hline Hemolytic uremic syndrome, postdiarrheal§ & 3 & 50 & 4 & 289 & 292 & 288 & 221 & 200 & $\mathrm{OH}(2), \mathrm{GA}(1)$ \\
\hline Hepatitis C viral, acute & 9 & 316 & 15 & 869 & 845 & 766 & 652 & 720 & IA (2), MD (1), WV (1), FL (3), OK (1), CA (1) \\
\hline HIV infection, pediatric (age $<13$ years) $\S$ & - & - & 3 & - & - & - & 380 & 436 & \\
\hline Influenza-associated pediatric mortality§, ๆๆ & 5 & 68 & 1 & 88 & 77 & 43 & 45 & - & $\mathrm{AZ}(1), \mathrm{CA}(2), \mathrm{CO}(1), \mathrm{IL}(1)$ \\
\hline Listeriosis & 6 & 185 & 11 & 760 & 808 & 884 & 896 & 753 & PA (1), DE (1), MD (1), VA (1), FL (1), CA (1) \\
\hline Measles*** & 5 & 25 & 2 & 140 & 43 & 55 & 66 & 37 & NYC (2), PA (2), TX (1) \\
\hline \multicolumn{10}{|l|}{ Meningococcal disease, invasive ${ }^{t+t}$ : } \\
\hline$A, C, Y$, and $W-135$ & - & 121 & 6 & 318 & 325 & 318 & 297 & - & \\
\hline serogroup $B$ & - & 60 & 3 & 185 & 167 & 193 & 156 & - & \\
\hline other serogroup & - & 10 & 1 & 34 & 35 & 32 & 27 & - & \\
\hline unknown serogroup & 10 & 222 & 14 & 626 & 550 & 651 & 765 & - & $\mathrm{PA}(1), \mathrm{OH}(1), \mathrm{MO}(2), \mathrm{NC}(1), \mathrm{FL}(1), \mathrm{CA}$ (4) \\
\hline Mumps & 1 & 138 & 60 & 450 & 800 & 6,584 & 314 & 258 & CA (1) \\
\hline Novel influenza A virus infections $§ \S \S$ & - & 11,054 & - & 2 & 4 & $\mathrm{~N}$ & $\mathrm{~N}$ & $\mathrm{~N}$ & \\
\hline Plague & - & - & 0 & 1 & 7 & 17 & 8 & 3 & \\
\hline Poliomyelitis, paralytic & - & - & - & - & - & - & 1 & - & \\
\hline Polio virus infection, nonparalytic§ & - & - & - & - & - & $\mathrm{N}$ & $\mathrm{N}$ & $\mathrm{N}$ & \\
\hline Psittacosis§ & - & 6 & 0 & 9 & 12 & 21 & 16 & 12 & \\
\hline$Q$ fever total§, १1ा1: & - & 24 & 4 & 120 & 171 & 169 & 136 & 70 & \\
\hline acute & - & 21 & 1 & 106 & - & - & - & - & \\
\hline chronic & - & 3 & 0 & 14 & - & - & - & - & \\
\hline Rabies, human & - & - & - & 1 & 1 & 3 & 2 & 7 & \\
\hline Rubella $a^{\star \star \star *}$ & - & 1 & 0 & 17 & 12 & 11 & 11 & 10 & \\
\hline Rubella, congenital syndrome & - & 1 & - & - & - & 1 & 1 & - & \\
\hline SARS-CoV§, †††† & - & - & - & - & - & - & - & - & \\
\hline Smallpox $\S$ & - & - & - & - & - & - & - & - & \\
\hline Streptococcal toxic-shock syndrome $\S$ & 1 & 68 & 3 & 158 & 132 & 125 & 129 & 132 & CT (1) \\
\hline Syphilis, congenital (age < 1 yr) & - & 66 & 8 & 418 & 430 & 349 & 329 & 353 & \\
\hline Tetanus & - & 4 & 1 & 19 & 28 & 41 & 27 & 34 & \\
\hline Toxic-shock syndrome (staphylococcal)§ & - & 33 & 2 & 73 & 92 & 101 & 90 & 95 & \\
\hline Trichinellosis & - & 9 & 0 & 38 & 5 & 15 & 16 & 5 & \\
\hline Tularemia & - & 11 & 3 & 122 & 137 & 95 & 154 & 134 & \\
\hline Typhoid fever & - & 121 & 6 & 444 & 434 & 353 & 324 & 322 & \\
\hline Vancomycin-intermediate Staphylococcus aureus $\S$ & 2 & 26 & 0 & 62 & 37 & 6 & 2 & - & $\mathrm{MO}(2)$ \\
\hline Vancomycin-resistant Staphylococcus aureus§ & - & - & 0 & - & 2 & 1 & 3 & 1 & \\
\hline Vibriosis (noncholera Vibrio species infections)§ & 7 & 81 & 3 & 491 & 549 & $\mathrm{~N}$ & $\mathrm{~N}$ & $\mathrm{~N}$ & $\mathrm{MN}(1), \mathrm{MD}(1), \mathrm{VA}(1), \mathrm{FL}(4)$ \\
\hline Yellow fever & - & - & - & - & - & - & - & - & \\
\hline
\end{tabular}

See Table I footnotes on next page. 
TABLE I. (Continued) Provisional cases of infrequently reported notifiable diseases $(<1,000$ cases reported during the preceding year) United States, week ending May 30, 2009 (21st week)

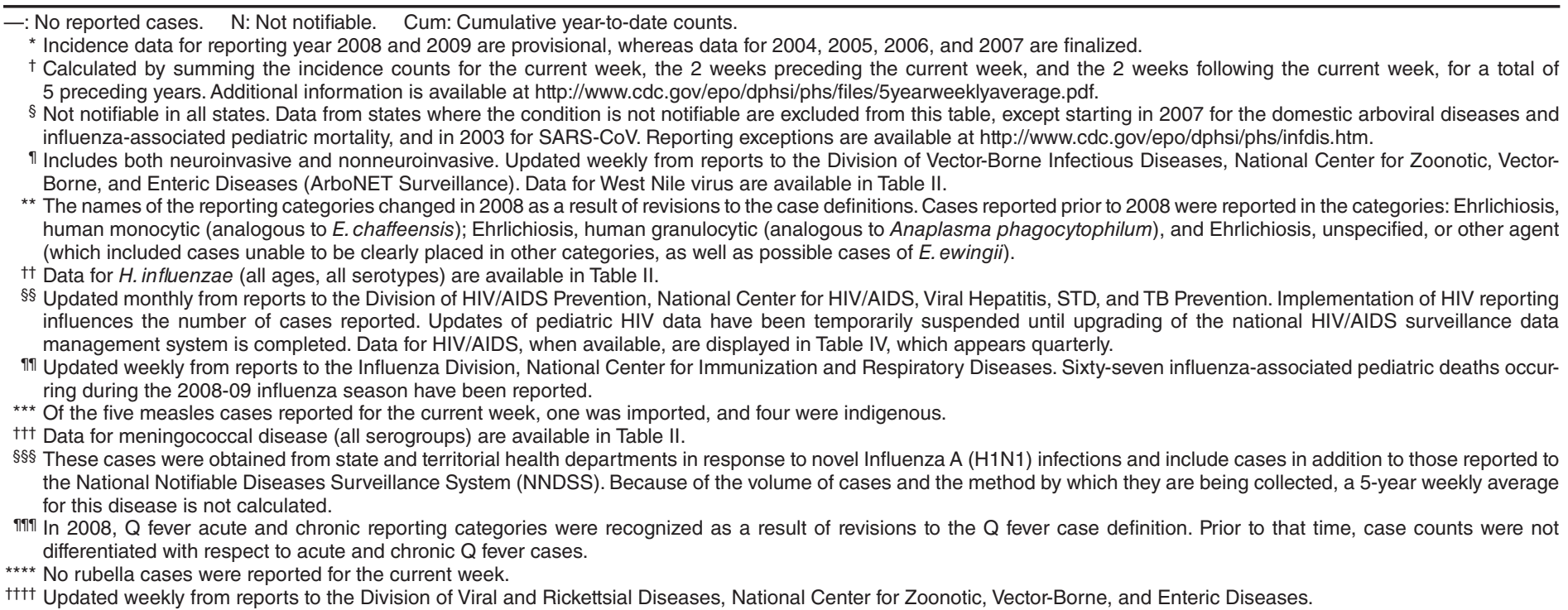

FIGURE I. Selected notifiable disease reports, United States, comparison of provisional 4-week totals May 30, 2009, with historical data

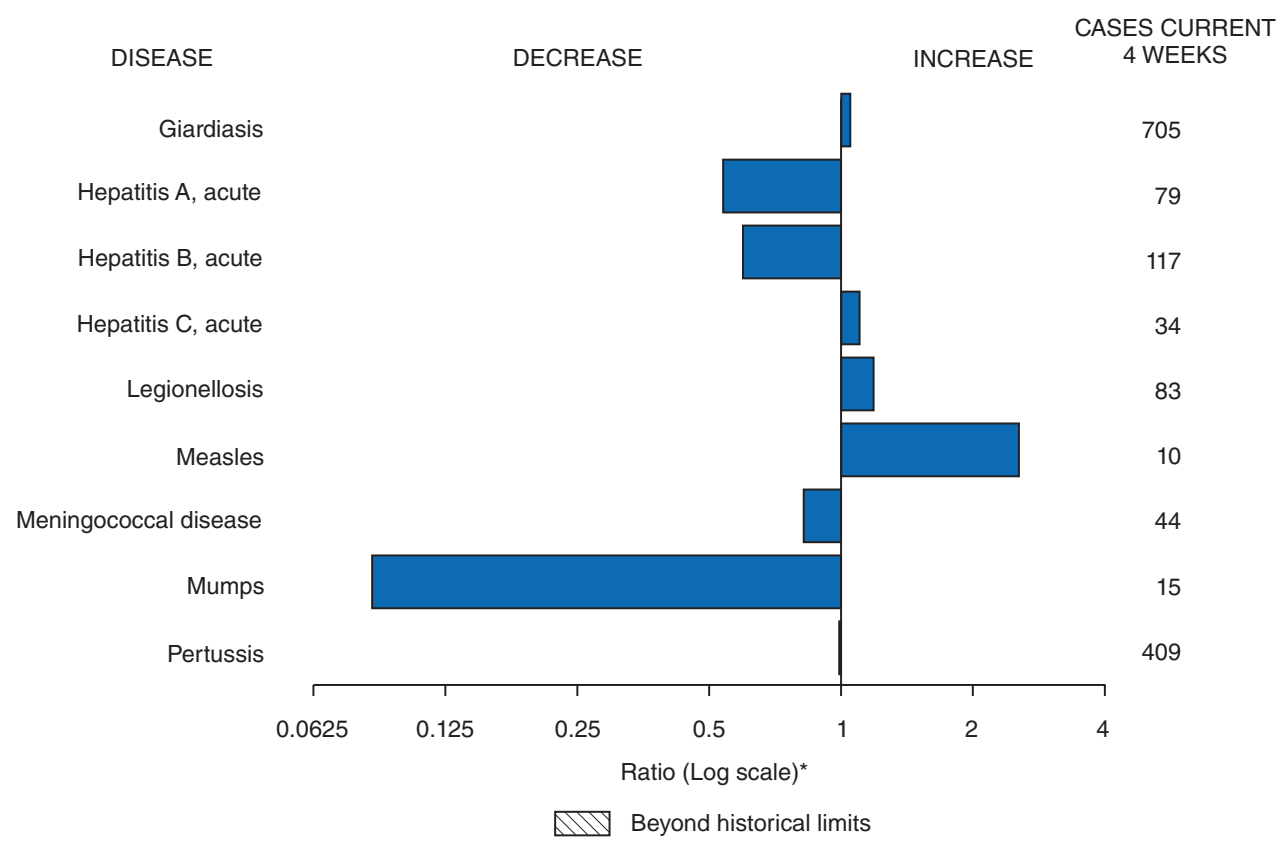

\footnotetext{
* Ratio of current 4-week total to mean of 15 4-week totals (from previous, comparable, and subsequent 4-week periods for the past 5 years). The point where the hatched area begins is based on the mean and two standard deviations of these 4-week totals.
}

\begin{tabular}{|c|c|}
\hline \multirow{2}{*}{\multicolumn{2}{|c|}{$\begin{array}{c}\text { Notifiable Disease Data Team and } 122 \text { Cities Mortality Data Team } \\
\text { Patsy A. Hall }\end{array}$}} \\
\hline & \\
\hline Deborah A. Adams & Rosaline Dhara \\
\hline Willie J. Anderson & Michael S. Wodajo \\
\hline Lenee Blanton & Pearl C. Sharp \\
\hline
\end{tabular}


TABLE II. Provisional cases of selected notifiable diseases, United States, weeks ending May 30, 2009, and May 24, 2008 (21st week)*

\begin{tabular}{|c|c|c|c|c|c|c|c|c|c|c|c|c|c|c|c|}
\hline \multirow[b]{3}{*}{ Reporting area } & \multicolumn{5}{|c|}{ Chlamydia ${ }^{\dagger}$} & \multicolumn{5}{|c|}{ Coccidiodomycosis } & \multicolumn{5}{|c|}{ Cryptosporidiosis } \\
\hline & \multirow{2}{*}{$\begin{array}{c}\text { Current } \\
\text { week }\end{array}$} & \multicolumn{2}{|c|}{$\begin{array}{l}\text { Previous } \\
52 \text { weeks }\end{array}$} & \multirow{2}{*}{$\begin{array}{l}\text { Cum } \\
2009\end{array}$} & \multirow{2}{*}{$\begin{array}{l}\text { Cum } \\
2008\end{array}$} & \multirow{2}{*}{$\begin{array}{c}\text { Current } \\
\text { week }\end{array}$} & \multicolumn{2}{|c|}{$\begin{array}{l}\text { Previous } \\
52 \text { weeks }\end{array}$} & \multirow{2}{*}{$\begin{array}{l}\text { Cum } \\
2009\end{array}$} & \multirow{2}{*}{$\begin{array}{l}\text { Cum } \\
2008\end{array}$} & \multirow{2}{*}{$\begin{array}{c}\text { Current } \\
\text { week }\end{array}$} & \multicolumn{2}{|c|}{$\begin{array}{l}\text { Previous } \\
52 \text { week }\end{array}$} & \multirow{2}{*}{$\begin{array}{l}\text { Cum } \\
2009\end{array}$} & \multirow{2}{*}{$\begin{array}{l}\text { Cum } \\
2008\end{array}$} \\
\hline & & Med & Max & & & & Med & $\operatorname{Max}$ & & & & Med & Max & & \\
\hline United States & 9,260 & 22,633 & 25,700 & 425,697 & 472,703 & 63 & 131 & 333 & 2,940 & 2,711 & 73 & 109 & 481 & 1,664 & 1,631 \\
\hline $\begin{array}{l}\text { New England } \\
\text { Connecticut } \\
\text { Maine } \\
\text { Massachusetts } \\
\text { New Hampshire } \\
\text { Rhode Island§ } \\
\text { Vermont } \$\end{array}$ & $\begin{array}{r}500 \\
181 \\
29 \\
270 \\
4 \\
-16\end{array}$ & $\begin{array}{r}760 \\
229 \\
48 \\
329 \\
32 \\
54 \\
22\end{array}$ & $\begin{array}{r}1,655 \\
1,306 \\
72 \\
950 \\
63 \\
244 \\
53\end{array}$ & $\begin{array}{r}15,793 \\
4,641 \\
1,034 \\
7,815 \\
459 \\
1,368 \\
476\end{array}$ & $\begin{array}{r}14,180 \\
3,748 \\
1,021 \\
6,901 \\
839 \\
1,230 \\
441\end{array}$ & $\begin{array}{l}\bar{N} \\
N \\
N \\
- \\
N\end{array}$ & $\begin{array}{l}0 \\
0 \\
0 \\
0 \\
0 \\
0 \\
0\end{array}$ & $\begin{array}{l}0 \\
0 \\
0 \\
0 \\
0 \\
0 \\
0\end{array}$ & $\begin{array}{l}\bar{N} \\
N \\
N \\
- \\
N\end{array}$ & $\begin{array}{r}1 \\
N \\
N \\
N \\
1 \\
N\end{array}$ & $\begin{array}{l}\frac{1}{1} \\
- \\
- \\
-\end{array}$ & $\begin{array}{l}5 \\
0 \\
1 \\
2 \\
1 \\
0 \\
1\end{array}$ & $\begin{array}{r}23 \\
9 \\
6 \\
13 \\
4 \\
3 \\
7\end{array}$ & $\begin{array}{r}91 \\
9 \\
10 \\
35 \\
16 \\
2 \\
19\end{array}$ & $\begin{array}{r}136 \\
41 \\
7 \\
38 \\
27 \\
3 \\
20\end{array}$ \\
\hline $\begin{array}{l}\text { Mid. Atlantic } \\
\text { New Jersey } \\
\text { New York (Upstate) } \\
\text { New York City } \\
\text { Pennsylvania }\end{array}$ & $\begin{array}{r}1,686 \\
397 \\
999 \\
290\end{array}$ & $\begin{array}{r}2,852 \\
380 \\
578 \\
1,092 \\
794\end{array}$ & $\begin{array}{r}6,734 \\
769 \\
4,563 \\
3,130 \\
1,072\end{array}$ & $\begin{array}{r}60,094 \\
6,310 \\
12,030 \\
25,006 \\
16,748\end{array}$ & $\begin{array}{r}60,680 \\
9,322 \\
10,626 \\
23,602 \\
17,130\end{array}$ & $\begin{array}{l}-\bar{N} \\
N \\
N \\
N\end{array}$ & $\begin{array}{l}0 \\
0 \\
0 \\
0 \\
0\end{array}$ & $\begin{array}{l}0 \\
0 \\
0 \\
0 \\
0\end{array}$ & $\begin{array}{l}-\bar{N} \\
N \\
N \\
N\end{array}$ & $\begin{array}{l}-\bar{N} \\
N \\
N \\
N\end{array}$ & $\frac{6}{\frac{6}{3}}$ & $\begin{array}{r}13 \\
0 \\
4 \\
1 \\
5\end{array}$ & $\begin{array}{r}35 \\
4 \\
17 \\
8 \\
15\end{array}$ & $\begin{array}{r}203 \\
1 \\
54 \\
28 \\
120\end{array}$ & $\begin{array}{r}199 \\
16 \\
52 \\
38 \\
93\end{array}$ \\
\hline $\begin{array}{l}\text { E.N. Central } \\
\text { Illinois } \\
\text { Indiana } \\
\text { Michigan } \\
\text { Ohio } \\
\text { Wisconsin }\end{array}$ & $\begin{array}{r}1,012 \\
468 \\
- \\
489 \\
19 \\
36\end{array}$ & $\begin{array}{r}3,404 \\
1,062 \\
394 \\
825 \\
783 \\
377\end{array}$ & $\begin{array}{r}4,382 \\
1,356 \\
713 \\
1,297 \\
1,300 \\
494\end{array}$ & $\begin{array}{r}62,118 \\
18,947 \\
8,447 \\
18,047 \\
9,987 \\
6,690\end{array}$ & $\begin{array}{r}79,744 \\
23,770 \\
8,931 \\
19,549 \\
18,590 \\
8,904\end{array}$ & $\begin{array}{l}1 \\
N \\
N \\
1 \\
N\end{array}$ & $\begin{array}{l}0 \\
0 \\
0 \\
0 \\
0 \\
0\end{array}$ & $\begin{array}{l}3 \\
0 \\
0 \\
3 \\
2 \\
0\end{array}$ & $\begin{array}{r}15 \\
N \\
N \\
6 \\
9 \\
N\end{array}$ & $\begin{array}{r}22 \\
\mathrm{~N} \\
\mathrm{~N} \\
17 \\
5 \\
\mathrm{~N}\end{array}$ & $\begin{array}{l}\frac{14}{-} \\
2 \\
12 \\
-\end{array}$ & $\begin{array}{r}25 \\
2 \\
3 \\
5 \\
7 \\
8\end{array}$ & $\begin{array}{r}125 \\
13 \\
17 \\
13 \\
59 \\
46\end{array}$ & $\begin{array}{r}371 \\
18 \\
58 \\
78 \\
127 \\
90\end{array}$ & $\begin{array}{r}388 \\
39 \\
55 \\
80 \\
86 \\
128\end{array}$ \\
\hline $\begin{array}{l}\text { W.N. Central } \\
\text { lowa } \\
\text { Kansas } \\
\text { Minnesota } \\
\text { Missouri } \\
\text { Nebraska§ } \\
\text { North Dakota } \\
\text { South Dakota }\end{array}$ & $\begin{array}{r}382 \\
140 \\
\overline{175} \\
27 \\
\overline{40}\end{array}$ & $\begin{array}{r}1,319 \\
191 \\
186 \\
265 \\
496 \\
97 \\
25 \\
56\end{array}$ & $\begin{array}{r}1,547 \\
257 \\
401 \\
316 \\
584 \\
254 \\
60 \\
85\end{array}$ & $\begin{array}{r}25,611 \\
3,601 \\
3,971 \\
4,392 \\
10,504 \\
1,770 \\
156 \\
1,217\end{array}$ & $\begin{array}{r}26,899 \\
3,506 \\
3,660 \\
5,990 \\
9,897 \\
1,979 \\
752 \\
1,115\end{array}$ & $\begin{array}{l}\bar{N} \\
N \\
- \\
\bar{N} \\
N \\
N\end{array}$ & $\begin{array}{l}0 \\
0 \\
0 \\
0 \\
0 \\
0 \\
0 \\
0\end{array}$ & $\begin{array}{l}1 \\
0 \\
0 \\
0 \\
1 \\
0 \\
0 \\
0\end{array}$ & $\begin{array}{l}1 \\
N \\
N \\
1 \\
N \\
N \\
N\end{array}$ & $\begin{array}{l}\bar{N} \\
N \\
- \\
N \\
N \\
N\end{array}$ & $\begin{array}{r}18 \\
1 \\
13 \\
2 \\
- \\
2\end{array}$ & $\begin{array}{r}17 \\
4 \\
1 \\
4 \\
3 \\
2 \\
0 \\
2\end{array}$ & $\begin{array}{r}68 \\
30 \\
8 \\
14 \\
13 \\
8 \\
10 \\
9\end{array}$ & $\begin{array}{r}253 \\
54 \\
23 \\
62 \\
47 \\
25 \\
1 \\
41\end{array}$ & $\begin{array}{r}244 \\
52 \\
21 \\
59 \\
55 \\
38 \\
19\end{array}$ \\
\hline $\begin{array}{l}\text { S. Atlantic } \\
\text { Delaware } \\
\text { District of Columbia } \\
\text { Florida } \\
\text { Georgia } \\
\text { Maryland } \$ \\
\text { North Carolina } \\
\text { South Carolina§ } \\
\text { Virginia§ } \\
\text { West Virginia }\end{array}$ & $\begin{array}{r}1,963 \\
104 \\
93 \\
424 \\
45 \\
- \\
671 \\
604 \\
22\end{array}$ & $\begin{array}{r}4,529 \\
72 \\
125 \\
1,386 \\
722 \\
441 \\
786 \\
544 \\
616 \\
68\end{array}$ & $\begin{array}{r}5,730 \\
180 \\
228 \\
1,906 \\
1,909 \\
772 \\
1,814 \\
887 \\
903 \\
101\end{array}$ & $\begin{array}{r}72,952 \\
1,982 \\
2,819 \\
29,741 \\
8,009 \\
7,621 \\
-122 \\
9,122 \\
12,094 \\
1,564\end{array}$ & $\begin{array}{r}90,973 \\
1,457 \\
2,828 \\
29,550 \\
16,135 \\
9,383 \\
7,650 \\
10,538 \\
12,071 \\
1,361\end{array}$ & $\begin{array}{l}- \\
- \\
N \\
N \\
-N \\
N \\
N \\
N\end{array}$ & $\begin{array}{l}0 \\
0 \\
0 \\
0 \\
0 \\
0 \\
0 \\
0 \\
0 \\
0\end{array}$ & $\begin{array}{l}1 \\
1 \\
0 \\
0 \\
0 \\
1 \\
0 \\
0 \\
0 \\
0\end{array}$ & $\begin{array}{l}4 \\
1 \\
N \\
N \\
3 \\
N \\
N \\
N \\
N\end{array}$ & $\begin{array}{l}2 \\
- \\
N \\
N \\
2 \\
N \\
N \\
N \\
N\end{array}$ & $\begin{array}{l}14 \\
- \\
9 \\
3 \\
1 \\
- \\
-1\end{array}$ & $\begin{array}{r}21 \\
0 \\
0 \\
8 \\
6 \\
1 \\
1 \\
1 \\
1 \\
0\end{array}$ & $\begin{array}{r}49 \\
1 \\
2 \\
35 \\
13 \\
5 \\
5 \\
16 \\
6 \\
4 \\
3\end{array}$ & $\begin{array}{r}331 \\
- \\
107 \\
130 \\
13 \\
43 \\
16 \\
17 \\
5\end{array}$ & $\begin{array}{r}290 \\
6 \\
7 \\
128 \\
89 \\
8 \\
9 \\
14 \\
20 \\
9\end{array}$ \\
\hline $\begin{array}{l}\text { E.S. Central } \\
\text { Alabama§ } \\
\text { Kentucky } \\
\text { Mississippi } \\
\text { Tennessee }\end{array}$ & $\begin{array}{r}924 \\
159 \\
399 \\
366\end{array}$ & $\begin{array}{r}1,694 \\
475 \\
240 \\
454 \\
562\end{array}$ & $\begin{array}{r}2,166 \\
581 \\
380 \\
841 \\
796\end{array}$ & $\begin{array}{r}35,270 \\
8,884 \\
4,269 \\
9,982 \\
12,135\end{array}$ & $\begin{array}{r}32,795 \\
10,259 \\
4,427 \\
7,052 \\
11,057\end{array}$ & $\begin{array}{l}-\bar{N} \\
N \\
N \\
N\end{array}$ & $\begin{array}{l}0 \\
0 \\
0 \\
0 \\
0\end{array}$ & $\begin{array}{l}0 \\
0 \\
0 \\
0 \\
0\end{array}$ & $\begin{array}{l}-\bar{N} \\
N \\
N \\
N\end{array}$ & $\begin{array}{l}\bar{N} \\
N \\
N \\
N\end{array}$ & $\begin{array}{l}- \\
- \\
-\end{array}$ & $\begin{array}{l}3 \\
1 \\
1 \\
0 \\
1\end{array}$ & $\begin{array}{l}9 \\
6 \\
4 \\
2 \\
5\end{array}$ & $\begin{array}{r}49 \\
12 \\
14 \\
4 \\
19\end{array}$ & $\begin{array}{r}47 \\
18 \\
10 \\
4 \\
15\end{array}$ \\
\hline $\begin{array}{l}\text { W.S. Central } \\
\text { Arkansas§ } \\
\text { Louisiana } \\
\text { Oklahoma } \\
\text { Texas }\end{array}$ & $\begin{array}{r}520 \\
193 \\
247 \\
80 \\
\end{array}$ & $\begin{array}{r}2,856 \\
278 \\
428 \\
185 \\
1,955\end{array}$ & $\begin{array}{r}3,987 \\
417 \\
1,114 \\
1,753 \\
2,511\end{array}$ & $\begin{array}{r}54,540 \\
5,962 \\
7,520 \\
2,349 \\
38,709\end{array}$ & $\begin{array}{r}60,066 \\
5,761 \\
8,101 \\
5,413 \\
40,791\end{array}$ & $\begin{array}{l}\bar{N} \\
\bar{N} \\
N\end{array}$ & $\begin{array}{l}0 \\
0 \\
0 \\
0 \\
0\end{array}$ & $\begin{array}{l}1 \\
0 \\
1 \\
0 \\
0\end{array}$ & $\begin{array}{l}\bar{N} \\
\bar{N} \\
N\end{array}$ & $\begin{array}{l}2 \\
N \\
2 \\
N \\
N\end{array}$ & $\begin{array}{r}4 \\
2 \\
2 \\
-\end{array}$ & $\begin{array}{l}8 \\
1 \\
1 \\
2 \\
3\end{array}$ & $\begin{array}{r}272 \\
10 \\
5 \\
16 \\
258\end{array}$ & $\begin{array}{r}59 \\
12 \\
6 \\
27 \\
14\end{array}$ & $\begin{array}{l}74 \\
15 \\
13 \\
16 \\
30\end{array}$ \\
\hline $\begin{array}{l}\text { Mountain } \\
\text { Arizona } \\
\text { Colorado } \\
\text { Idaho§ } \\
\text { Montana§ } \\
\text { Nevada§ } \\
\text { New Mexico§ } \\
\text { Utah } \\
\text { Wyoming§ }\end{array}$ & $\begin{array}{r}552 \\
71 \\
250 \\
177 \\
11 \\
18 \\
- \\
25\end{array}$ & $\begin{array}{r}1,356 \\
449 \\
323 \\
68 \\
58 \\
174 \\
159 \\
85 \\
34\end{array}$ & $\begin{array}{r}2,145 \\
627 \\
1,109 \\
314 \\
89 \\
365 \\
540 \\
251 \\
97\end{array}$ & $\begin{array}{r}24,903 \\
6,476 \\
7,202 \\
1,563 \\
1,227 \\
3,970 \\
2,452 \\
1,125 \\
888\end{array}$ & $\begin{array}{r}29,980 \\
9,932 \\
7,321 \\
1,521 \\
1,273 \\
4,071 \\
2,819 \\
2,481 \\
562\end{array}$ & $\begin{array}{r}40 \\
40 \\
N \\
N \\
N \\
- \\
- \\
-\end{array}$ & $\begin{array}{r}92 \\
90 \\
0 \\
0 \\
0 \\
1 \\
0 \\
0 \\
0\end{array}$ & $\begin{array}{r}211 \\
209 \\
0 \\
0 \\
0 \\
3 \\
2 \\
1 \\
1\end{array}$ & $\begin{array}{r}2,070 \\
2,036 \\
\mathrm{~N} \\
\mathrm{~N} \\
\mathrm{~N} \\
27 \\
2 \\
5 \\
-\end{array}$ & $\begin{array}{r}1,839 \\
1,789 \\
N \\
N \\
N \\
26 \\
16 \\
8 \\
-\end{array}$ & $\begin{array}{l}\frac{4}{4} \\
- \\
- \\
- \\
-\end{array}$ & $\begin{array}{l}8 \\
1 \\
1 \\
1 \\
0 \\
0 \\
2 \\
0 \\
0\end{array}$ & $\begin{array}{r}38 \\
10 \\
12 \\
5 \\
4 \\
4 \\
23 \\
6 \\
2\end{array}$ & $\begin{array}{r}113 \\
11 \\
34 \\
16 \\
13 \\
6 \\
24 \\
1 \\
8\end{array}$ & $\begin{array}{r}128 \\
14 \\
27 \\
23 \\
17 \\
5 \\
25 \\
10 \\
7\end{array}$ \\
\hline $\begin{array}{l}\text { Pacific } \\
\text { Alaska } \\
\text { California } \\
\text { Hawaii } \\
\text { Oregon } \\
\text { Washington }\end{array}$ & $\begin{array}{r}1,721 \\
71 \\
1,167 \\
61 \\
223 \\
199\end{array}$ & $\begin{array}{r}3,660 \\
89 \\
2,869 \\
115 \\
188 \\
403\end{array}$ & $\begin{array}{r}4,605 \\
199 \\
3,583 \\
247 \\
631 \\
557\end{array}$ & $\begin{array}{r}74,416 \\
1,837 \\
58,677 \\
2,338 \\
3,796 \\
7,768\end{array}$ & $\begin{array}{r}77,386 \\
1,916 \\
60,086 \\
2,348 \\
4,244 \\
8,792\end{array}$ & $\begin{array}{r}22 \\
N \\
22 \\
N \\
N \\
N\end{array}$ & $\begin{array}{r}37 \\
0 \\
37 \\
0 \\
0 \\
0\end{array}$ & $\begin{array}{r}172 \\
0 \\
172 \\
0 \\
0 \\
0\end{array}$ & $\begin{array}{r}850 \\
N \\
850 \\
N \\
N \\
N\end{array}$ & $\begin{array}{r}845 \\
N \\
845 \\
N \\
N \\
N\end{array}$ & $\frac{\frac{12}{10}}{\frac{-}{2}}$ & $\begin{array}{l}9 \\
0 \\
6 \\
0 \\
1 \\
2\end{array}$ & $\begin{array}{r}33 \\
1 \\
14 \\
1 \\
31 \\
10\end{array}$ & $\begin{array}{r}194 \\
2 \\
109 \\
1 \\
60 \\
22\end{array}$ & $\begin{array}{r}125 \\
1 \\
77 \\
1 \\
23 \\
23\end{array}$ \\
\hline $\begin{array}{l}\text { American Samoa } \\
\text { C.N.M.I. } \\
\text { Guam } \\
\text { Puerto Rico }\end{array}$ & $\frac{-}{166}$ & $\begin{array}{r}\frac{0}{4} \\
134\end{array}$ & $\begin{array}{r}\frac{8}{9} \\
269\end{array}$ & $\frac{-}{3,076}$ & $\begin{array}{r}\frac{62}{81} \\
2,759\end{array}$ & $\frac{\mathrm{N}}{\mathrm{N}}$ & $\begin{array}{l}0 \\
0 \\
0\end{array}$ & $\begin{array}{l}0 \\
0 \\
0\end{array}$ & $\frac{\mathrm{N}}{\mathrm{N}}$ & $\frac{\mathrm{N}}{\mathrm{N}}$ & $\frac{\mathrm{N}}{\mathrm{N}}$ & $\begin{array}{l}0 \\
0 \\
0\end{array}$ & $\begin{array}{l}0 \\
0 \\
0\end{array}$ & $\frac{\mathrm{N}}{\mathrm{N}}$ & $\frac{\mathrm{N}}{\mathrm{N}}$ \\
\hline U.S. Virgin Islands & - & 9 & 40 & 106 & 280 & - & 0 & 0 & - & - & - & 0 & 0 & - & - \\
\hline
\end{tabular}

C.N.M.I.: Commonwealth of Northern Mariana Islands.

U: Unavailable. - No reported cases. N: Not notifiable. Cum: Cumulative year-to-date counts. Med: Median. Max: Maximum.

* Incidence data for reporting year 2008 and 2009 are provisional. Data for HIV/AIDS, AIDS, and TB, when available, are displayed in Table IV, which appears quarterly.

† Chlamydia refers to genital infections caused by Chlamydia trachomatis.

$\S$ Contains data reported through the National Electronic Disease Surveillance System (NEDSS). 
TABLE II. (Continued) Provisional cases of selected notifiable diseases, United States, weeks ending May 30, 2009, and May 24, 2008 (21st week)*

\begin{tabular}{|c|c|c|c|c|c|c|c|c|c|c|c|c|c|c|c|}
\hline \multirow[b]{3}{*}{ Reporting area } & \multicolumn{5}{|c|}{ Giardiasis } & \multicolumn{5}{|c|}{ Gonorrhea } & \multicolumn{5}{|c|}{$\begin{array}{c}\text { Haemophilus influenzae, invasive } \\
\text { All ages, all serotypes }{ }^{\dagger}\end{array}$} \\
\hline & \multirow{2}{*}{$\begin{array}{c}\text { Current } \\
\text { week }\end{array}$} & \multicolumn{2}{|c|}{$\begin{array}{l}\text { Previous } \\
52 \text { weeks }\end{array}$} & \multirow{2}{*}{$\begin{array}{l}\text { Cum } \\
2009 \\
\end{array}$} & \multirow{2}{*}{$\begin{array}{l}\text { Cum } \\
2008 \\
\end{array}$} & \multirow{2}{*}{$\begin{array}{c}\text { Current } \\
\text { week }\end{array}$} & \multicolumn{2}{|c|}{$\begin{array}{l}\text { Previous } \\
52 \text { weeks }\end{array}$} & \multirow{2}{*}{$\begin{array}{l}\text { Cum } \\
2009\end{array}$} & \multirow{2}{*}{$\begin{array}{l}\text { Cum } \\
2008 \\
\end{array}$} & \multirow{2}{*}{$\begin{array}{c}\text { Current } \\
\text { week }\end{array}$} & \multicolumn{2}{|c|}{$\begin{array}{l}\text { Previous } \\
52 \text { weeks }\end{array}$} & \multirow{2}{*}{$\begin{array}{l}\text { Cum } \\
2009 \\
\end{array}$} & \multirow{2}{*}{$\begin{array}{l}\text { Cum } \\
2008 \\
\end{array}$} \\
\hline & & Med & Max & & & & Med & Max & & & & Med & Max & & \\
\hline United States & 204 & 316 & 640 & 5,688 & 5,990 & 1,981 & 5,884 & 7,164 & 99,051 & 132,116 & 23 & 49 & 126 & 1,104 & 1,301 \\
\hline $\begin{array}{l}\text { New England } \\
\text { Connecticut } \\
\text { Maine } \\
\text { Massachusetts } \\
\text { New Hampshire } \\
\text { Rhode Island\$ } \\
\text { Vermont } \$\end{array}$ & $\begin{array}{l}\frac{2}{2} \\
- \\
- \\
-\end{array}$ & $\begin{array}{r}28 \\
5 \\
4 \\
11 \\
2 \\
1 \\
3\end{array}$ & $\begin{array}{r}64 \\
14 \\
12 \\
27 \\
10 \\
8 \\
15\end{array}$ & $\begin{array}{r}401 \\
76 \\
75 \\
150 \\
33 \\
18 \\
49\end{array}$ & $\begin{array}{r}503 \\
122 \\
43 \\
214 \\
42 \\
33 \\
49\end{array}$ & $\begin{array}{r}65 \\
30 \\
31 \\
4 \\
- \\
-\end{array}$ & $\begin{array}{r}96 \\
51 \\
2 \\
38 \\
1 \\
5 \\
1\end{array}$ & $\begin{array}{r}301 \\
275 \\
9 \\
112 \\
6 \\
16 \\
4\end{array}$ & $\begin{array}{r}1,925 \\
879 \\
58 \\
800 \\
45 \\
120 \\
23\end{array}$ & $\begin{array}{r}1,972 \\
811 \\
40 \\
922 \\
51 \\
134 \\
14\end{array}$ & $\begin{array}{l}1 \\
- \\
- \\
\overline{1}\end{array}$ & $\begin{array}{l}3 \\
0 \\
0 \\
1 \\
0 \\
0 \\
0\end{array}$ & $\begin{array}{r}18 \\
12 \\
2 \\
5 \\
2 \\
7 \\
1\end{array}$ & $\begin{array}{r}74 \\
24 \\
11 \\
32 \\
2 \\
2 \\
3\end{array}$ & $\begin{array}{r}70 \\
13 \\
6 \\
38 \\
5 \\
2 \\
6\end{array}$ \\
\hline $\begin{array}{l}\text { Mid. Atlantic } \\
\text { New Jersey } \\
\text { New York (Upstate) } \\
\text { New York City } \\
\text { Pennsylvania }\end{array}$ & $\begin{array}{r}27 \\
21 \\
2 \\
4\end{array}$ & $\begin{array}{r}61 \\
8 \\
23 \\
15 \\
16\end{array}$ & $\begin{array}{r}116 \\
21 \\
81 \\
30 \\
46\end{array}$ & $\begin{array}{r}1,052 \\
85 \\
429 \\
283 \\
255\end{array}$ & $\begin{array}{r}1,189 \\
194 \\
380 \\
347 \\
268\end{array}$ & $\begin{array}{r}298 \\
51 \\
191 \\
56\end{array}$ & $\begin{array}{r}607 \\
82 \\
116 \\
209 \\
192\end{array}$ & $\begin{array}{r}1,138 \\
144 \\
664 \\
577 \\
267\end{array}$ & $\begin{array}{r}11,591 \\
1,267 \\
2,172 \\
4,505 \\
3,647\end{array}$ & $\begin{array}{r}13,045 \\
2,169 \\
2,407 \\
3,989 \\
4,480\end{array}$ & $\begin{array}{l}\frac{5}{2} \\
2 \\
1\end{array}$ & $\begin{array}{r}10 \\
1 \\
3 \\
2 \\
4\end{array}$ & $\begin{array}{r}25 \\
7 \\
20 \\
10 \\
10\end{array}$ & $\begin{array}{r}221 \\
14 \\
54 \\
53 \\
100\end{array}$ & $\begin{array}{r}232 \\
39 \\
62 \\
41 \\
90\end{array}$ \\
\hline $\begin{array}{l}\text { E.N. Central } \\
\text { Illinois } \\
\text { Indiana } \\
\text { Michigan } \\
\text { Ohio } \\
\text { Wisconsin }\end{array}$ & $\begin{array}{r}13 \\
\mathrm{~N} \\
2 \\
11 \\
-\end{array}$ & $\begin{array}{r}46 \\
10 \\
0 \\
12 \\
16 \\
8\end{array}$ & $\begin{array}{l}89 \\
32 \\
11 \\
22 \\
31 \\
20\end{array}$ & $\begin{array}{r}803 \\
133 \\
N \\
217 \\
308 \\
145\end{array}$ & $\begin{array}{r}909 \\
238 \\
N \\
201 \\
320 \\
150\end{array}$ & $\begin{array}{r}286 \\
159 \\
111 \\
3 \\
13\end{array}$ & $\begin{array}{r}1,143 \\
352 \\
154 \\
291 \\
254 \\
102\end{array}$ & $\begin{array}{r}1,627 \\
499 \\
256 \\
493 \\
482 \\
149\end{array}$ & $\begin{array}{r}18,995 \\
5,654 \\
2,764 \\
5,818 \\
2,993 \\
1,766\end{array}$ & $\begin{array}{r}28,449 \\
8,013 \\
3,607 \\
7,306 \\
6,888 \\
2,635\end{array}$ & $\begin{array}{l}\frac{4}{二} \\
\frac{4}{-}\end{array}$ & $\begin{array}{l}6 \\
2 \\
1 \\
0 \\
1 \\
0\end{array}$ & $\begin{array}{r}27 \\
9 \\
22 \\
3 \\
6 \\
2\end{array}$ & $\begin{array}{r}125 \\
38 \\
21 \\
12 \\
47 \\
7\end{array}$ & $\begin{array}{r}199 \\
64 \\
39 \\
13 \\
66 \\
17\end{array}$ \\
\hline $\begin{array}{l}\text { W.N. Central } \\
\text { lowa } \\
\text { Kansas } \\
\text { Minnesota } \\
\text { Missouri } \\
\text { Nebraska§ } \\
\text { North Dakota } \\
\text { South Dakota }\end{array}$ & $\begin{array}{l}10 \\
5 \\
\frac{-}{5} \\
- \\
-\end{array}$ & $\begin{array}{r}26 \\
6 \\
3 \\
0 \\
8 \\
3 \\
0 \\
2\end{array}$ & $\begin{array}{r}143 \\
18 \\
11 \\
106 \\
22 \\
10 \\
16 \\
11\end{array}$ & $\begin{array}{r}531 \\
97 \\
48 \\
137 \\
174 \\
47 \\
3 \\
25\end{array}$ & $\begin{array}{r}606 \\
100 \\
40 \\
191 \\
166 \\
76 \\
7 \\
26\end{array}$ & $\begin{array}{l}\frac{106}{45} \\
\frac{38}{38} \\
\frac{11}{12}\end{array}$ & $\begin{array}{r}305 \\
30 \\
40 \\
50 \\
143 \\
27 \\
1 \\
8\end{array}$ & $\begin{array}{r}393 \\
53 \\
83 \\
78 \\
184 \\
50 \\
7 \\
20\end{array}$ & $\begin{array}{r}5,469 \\
565 \\
915 \\
704 \\
2,602 \\
514 \\
6 \\
163\end{array}$ & $\begin{array}{r}6,706 \\
614 \\
891 \\
1,324 \\
3,184 \\
545 \\
47 \\
101\end{array}$ & $\begin{array}{l}\frac{1}{二} \\
\overline{1} \\
\overline{-} \\
-\end{array}$ & $\begin{array}{l}3 \\
0 \\
0 \\
0 \\
1 \\
0 \\
0 \\
0\end{array}$ & $\begin{array}{r}15 \\
0 \\
2 \\
10 \\
4 \\
2 \\
4 \\
0\end{array}$ & $\begin{array}{r}72 \\
9 \\
15 \\
34 \\
11 \\
3 \\
-\end{array}$ & $\begin{array}{r}96 \\
2 \\
11 \\
18 \\
44 \\
14 \\
7 \\
-\end{array}$ \\
\hline $\begin{array}{l}\text { S. Atlantic } \\
\text { Delaware } \\
\text { District of Columbia } \\
\text { Florida } \\
\text { Georgia } \\
\text { Maryland\$ } \\
\text { North Carolina } \\
\text { South Carolina } \\
\text { Virginia } \\
\text { West Virginia }\end{array}$ & $\begin{array}{r}96 \\
- \\
25 \\
62 \\
4 \\
N \\
1 \\
3 \\
1\end{array}$ & $\begin{array}{r}66 \\
1 \\
0 \\
31 \\
13 \\
6 \\
0 \\
2 \\
8 \\
1\end{array}$ & $\begin{array}{r}108 \\
3 \\
5 \\
57 \\
63 \\
10 \\
0 \\
8 \\
81 \\
5\end{array}$ & $\begin{array}{r}1,403 \\
12 \\
703 \\
393 \\
92 \\
\mathrm{~N} \\
38 \\
148 \\
17\end{array}$ & $\begin{array}{r}988 \\
17 \\
22 \\
442 \\
221 \\
91 \\
N \\
48 \\
117 \\
30\end{array}$ & $\begin{array}{r}561 \\
27 \\
42 \\
153 \\
8 \\
- \\
- \\
189 \\
139 \\
3\end{array}$ & $\begin{array}{r}1,531 \\
16 \\
52 \\
419 \\
263 \\
121 \\
302 \\
169 \\
163 \\
12\end{array}$ & $\begin{array}{r}2,142 \\
35 \\
89 \\
592 \\
876 \\
212 \\
647 \\
316 \\
321 \\
26\end{array}$ & $\begin{array}{r}20,284 \\
340 \\
1,161 \\
8,512 \\
2,613 \\
1,990 \\
2,731 \\
2,711 \\
226\end{array}$ & $\begin{array}{r}31,417 \\
477 \\
988 \\
9,945 \\
5,768 \\
2,441 \\
3,796 \\
3,869 \\
3,813 \\
320\end{array}$ & $\begin{array}{l}\frac{6}{-} \\
\frac{2}{-} \\
\frac{4}{-} \\
-\end{array}$ & $\begin{array}{r}13 \\
0 \\
0 \\
4 \\
2 \\
1 \\
1 \\
1 \\
1 \\
0\end{array}$ & $\begin{array}{r}26 \\
2 \\
2 \\
9 \\
9 \\
6 \\
17 \\
5 \\
6 \\
3\end{array}$ & $\begin{array}{r}332 \\
3 \\
117 \\
69 \\
40 \\
41 \\
23 \\
24 \\
15\end{array}$ & $\begin{array}{r}328 \\
3 \\
2 \\
87 \\
70 \\
54 \\
30 \\
29 \\
43 \\
10\end{array}$ \\
\hline $\begin{array}{l}\text { E.S. Central } \\
\text { Alabama§ } \\
\text { Kentucky } \\
\text { Mississippi } \\
\text { Tennessee§ }\end{array}$ & $\begin{array}{l}1 \\
1 \\
N \\
N \\
-\end{array}$ & $\begin{array}{l}8 \\
4 \\
0 \\
0 \\
4\end{array}$ & $\begin{array}{r}22 \\
12 \\
0 \\
0 \\
13\end{array}$ & $\begin{array}{r}112 \\
53 \\
N \\
N \\
59\end{array}$ & $\begin{array}{r}156 \\
84 \\
N \\
N \\
72\end{array}$ & $\begin{array}{r}267 \\
43 \\
121 \\
103\end{array}$ & $\begin{array}{r}541 \\
164 \\
86 \\
144 \\
160\end{array}$ & $\begin{array}{l}771 \\
216 \\
153 \\
253 \\
301\end{array}$ & $\begin{array}{r}10,149 \\
2,567 \\
1,264 \\
3,044 \\
3,274\end{array}$ & $\begin{array}{r}11,827 \\
4,072 \\
1,699 \\
2,634 \\
3,422\end{array}$ & $\begin{array}{l}E \\
\overline{-} \\
-\end{array}$ & $\begin{array}{l}3 \\
0 \\
0 \\
0 \\
2\end{array}$ & $\begin{array}{l}6 \\
4 \\
2 \\
1 \\
5\end{array}$ & $\begin{array}{r}62 \\
18 \\
7 \\
37\end{array}$ & $\begin{array}{r}76 \\
9 \\
6 \\
11 \\
50\end{array}$ \\
\hline $\begin{array}{l}\text { W.S. Central } \\
\text { Arkansas } \\
\text { Louisiana } \\
\text { Oklahoma } \\
\text { Texas } \$\end{array}$ & $\begin{array}{l}\frac{6}{-} \\
6 \\
N\end{array}$ & $\begin{array}{l}7 \\
2 \\
2 \\
3 \\
0\end{array}$ & $\begin{array}{r}22 \\
8 \\
10 \\
18 \\
0\end{array}$ & $\begin{array}{r}113 \\
43 \\
37 \\
33 \\
\mathrm{~N}\end{array}$ & $\begin{array}{r}111 \\
45 \\
39 \\
27 \\
\mathrm{~N}\end{array}$ & $\begin{array}{r}144 \\
62 \\
66 \\
16 \\
-\end{array}$ & $\begin{array}{r}930 \\
83 \\
156 \\
70 \\
590\end{array}$ & $\begin{array}{r}1,307 \\
167 \\
421 \\
437 \\
725\end{array}$ & $\begin{array}{r}15,654 \\
1,768 \\
2,263 \\
1,185 \\
10,438\end{array}$ & $\begin{array}{r}20,606 \\
1,811 \\
3,774 \\
1,972 \\
13,049\end{array}$ & $\frac{1}{-}$ & $\begin{array}{l}2 \\
0 \\
0 \\
1 \\
0\end{array}$ & $\begin{array}{r}22 \\
2 \\
1 \\
20 \\
1\end{array}$ & $\begin{array}{r}52 \\
8 \\
8 \\
36 \\
-\end{array}$ & $\begin{array}{r}64 \\
5 \\
6 \\
48 \\
5\end{array}$ \\
\hline $\begin{array}{l}\text { Mountain } \\
\text { Arizona } \\
\text { Colorado } \\
\text { Idaho§ } \\
\text { Montana§ } \\
\text { Nevada§ } \\
\text { New Mexico§ } \\
\text { Utah } \\
\text { Wyoming }\end{array}$ & $\begin{array}{l}\frac{11}{10} \\
1 \\
- \\
- \\
-\end{array}$ & $\begin{array}{r}27 \\
3 \\
9 \\
3 \\
2 \\
2 \\
1 \\
7 \\
1\end{array}$ & $\begin{array}{r}62 \\
10 \\
27 \\
14 \\
9 \\
8 \\
8 \\
18 \\
4\end{array}$ & $\begin{array}{r}396 \\
66 \\
135 \\
38 \\
36 \\
30 \\
28 \\
47 \\
16\end{array}$ & $\begin{array}{r}468 \\
45 \\
177 \\
49 \\
25 \\
41 \\
35 \\
83 \\
13\end{array}$ & $\begin{array}{r}35 \\
12 \\
16 \\
3 \\
4 \\
- \\
-\end{array}$ & $\begin{array}{r}200 \\
57 \\
62 \\
3 \\
2 \\
34 \\
23 \\
5 \\
2\end{array}$ & $\begin{array}{r}371 \\
82 \\
293 \\
13 \\
6 \\
86 \\
52 \\
15 \\
8\end{array}$ & $\begin{array}{r}3,242 \\
743 \\
1,275 \\
41 \\
34 \\
729 \\
332 \\
62 \\
26\end{array}$ & $\begin{array}{r}4,922 \\
1,459 \\
1,483 \\
70 \\
46 \\
1,029 \\
549 \\
248 \\
38\end{array}$ & $\begin{array}{l}3 \\
1 \\
2 \\
- \\
= \\
= \\
= \\
-\end{array}$ & $\begin{array}{l}5 \\
1 \\
1 \\
0 \\
0 \\
0 \\
1 \\
0 \\
0\end{array}$ & $\begin{array}{r}11 \\
7 \\
5 \\
2 \\
1 \\
2 \\
3 \\
2 \\
2\end{array}$ & $\begin{array}{r}113 \\
45 \\
31 \\
2 \\
1 \\
9 \\
14 \\
11 \\
-\end{array}$ & $\begin{array}{r}161 \\
68 \\
28 \\
6 \\
1 \\
9 \\
24 \\
25 \\
-\end{array}$ \\
\hline $\begin{array}{l}\text { Pacific } \\
\text { Alaska } \\
\text { California } \\
\text { Hawaii } \\
\text { Oregon§ } \\
\text { Washington }\end{array}$ & $\begin{array}{r}38 \\
1 \\
33 \\
- \\
4\end{array}$ & $\begin{array}{r}54 \\
2 \\
34 \\
0 \\
7 \\
7\end{array}$ & $\begin{array}{r}127 \\
10 \\
59 \\
4 \\
66 \\
74\end{array}$ & $\begin{array}{r}877 \\
24 \\
625 \\
5 \\
122 \\
101\end{array}$ & $\begin{array}{r}1,060 \\
29 \\
738 \\
14 \\
179 \\
100\end{array}$ & $\begin{array}{r}219 \\
11 \\
165 \\
1 \\
25 \\
17\end{array}$ & $\begin{array}{r}575 \\
13 \\
480 \\
13 \\
22 \\
51\end{array}$ & $\begin{array}{r}755 \\
24 \\
657 \\
19 \\
48 \\
81\end{array}$ & $\begin{array}{r}11,742 \\
296 \\
9,918 \\
253 \\
414 \\
861\end{array}$ & $\begin{array}{r}13,172 \\
206 \\
10,829 \\
234 \\
531 \\
1,372\end{array}$ & $\begin{array}{l}2 \\
2 \\
= \\
-\end{array}$ & $\begin{array}{l}2 \\
0 \\
0 \\
0 \\
1 \\
0\end{array}$ & $\begin{array}{r}13 \\
2 \\
3 \\
2 \\
12 \\
2\end{array}$ & $\begin{array}{r}53 \\
6 \\
7 \\
13 \\
24 \\
3\end{array}$ & $\begin{array}{r}75 \\
9 \\
27 \\
8 \\
29 \\
2\end{array}$ \\
\hline $\begin{array}{l}\text { American Samoa } \\
\text { C.N.M.I. }\end{array}$ & 二 & $\underline{0}$ & $\underline{0}$ & - & 二 & - & $\frac{0}{-}$ & 1 & 二 & $\frac{2}{-}$ & 二 & $\frac{0}{-}$ & $\underline{0}$ & - & 二 \\
\hline $\begin{array}{l}\text { Guam } \\
\text { Puerto Rico }\end{array}$ & - & $\begin{array}{l}0 \\
3\end{array}$ & $\begin{array}{r}0 \\
15\end{array}$ & $\overline{25}$ & $\overline{55}$ & $\overline{5}$ & $\begin{array}{l}2 \\
4\end{array}$ & $\begin{array}{l}15 \\
16\end{array}$ & $\overline{88}$ & $\begin{array}{r}23 \\
115\end{array}$ & - & $\begin{array}{l}0 \\
0\end{array}$ & $\begin{array}{l}0 \\
1\end{array}$ & - & 二 \\
\hline U.S. Virgin Islands & - & 0 & 0 & - & - & - & 2 & 6 & 23 & 49 & $\mathrm{~N}$ & 0 & 0 & $\mathrm{~N}$ & $\mathrm{~N}$ \\
\hline
\end{tabular}

C.N.M.I.: Commonwealth of Northern Mariana Islands.

* Incidence data for reporting year 2008 and 2009 are provisional.

† Data for $H$. influenzae (age $<5$ yrs for serotype $b$, nonserotype $b$, and unknown serotype) are available in Table I.

$\S$ Contains data reported through the National Electronic Disease Surveillance System (NEDSS). 
TABLE II. (Continued) Provisional cases of selected notifiable diseases, United States, weeks ending May 30, 2009, and May 24, 2008 (21st week)*

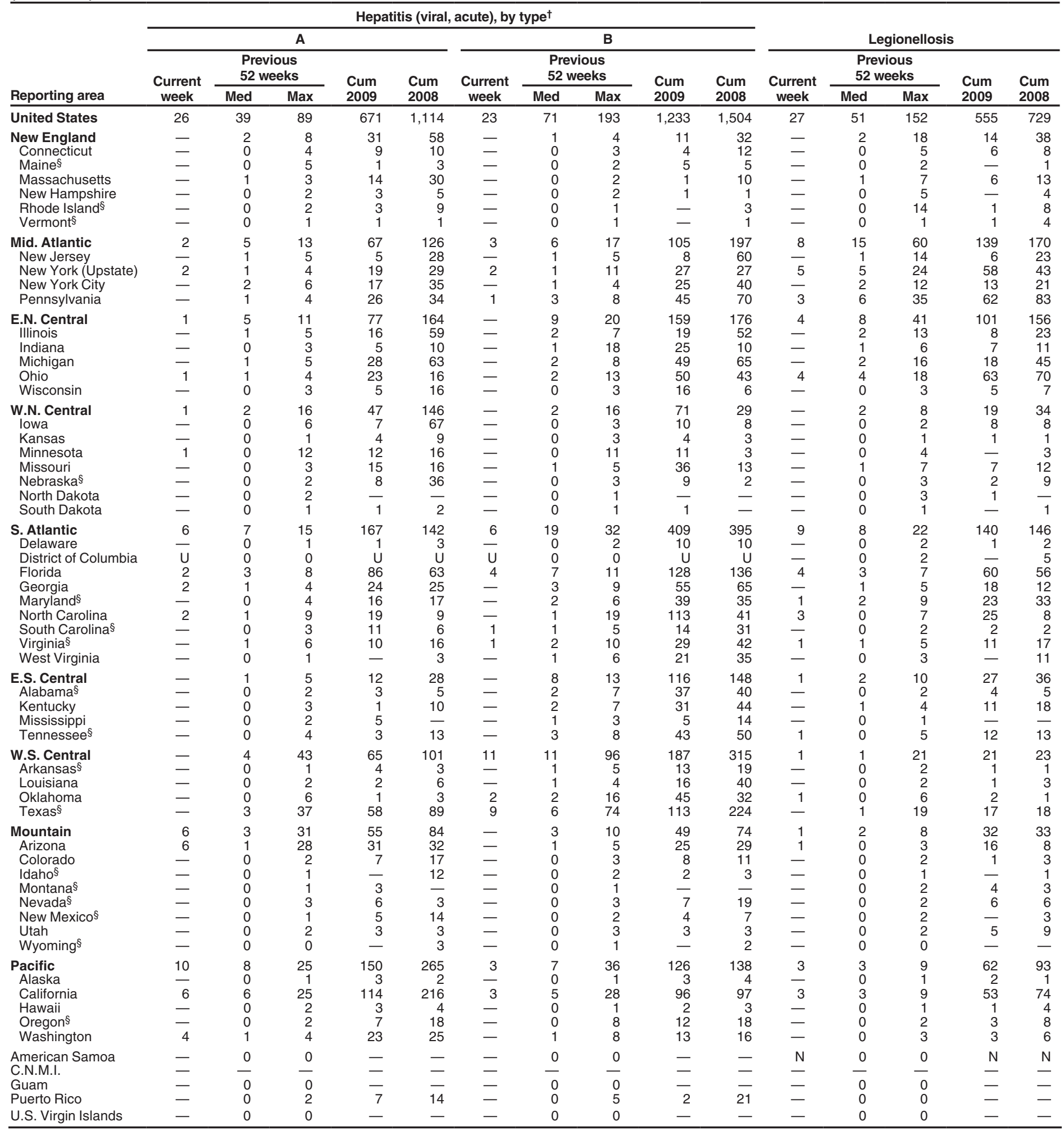

C.N.M.I.: Commonwealth of Northern Mariana Islands.

U: Unavailable. - : No reported cases. N: Not notifiable. Cum: Cumulative year-to-date counts. Med: Median. Max: Maximum.

* Incidence data for reporting year 2008 and 2009 are provisional.

† Data for acute hepatitis C, viral are available in Table

$\S$ Contains data reported through the National Electronic Disease Surveillance System (NEDSS). 
TABLE II. (Continued) Provisional cases of selected notifiable diseases, United States, weeks ending May 30, 2009, and May 24, 2008 (21st week)*

\begin{tabular}{|c|c|c|c|c|c|c|c|c|c|c|c|c|c|c|c|}
\hline \multirow[b]{3}{*}{ Reporting area } & \multicolumn{5}{|c|}{ Lyme disease } & \multicolumn{5}{|c|}{ Malaria } & \multicolumn{5}{|c|}{$\begin{array}{l}\text { Meningococcal disease, invasive }{ }^{\dagger} \\
\text { All serotypes }\end{array}$} \\
\hline & \multirow{2}{*}{$\begin{array}{c}\text { Current } \\
\text { week }\end{array}$} & \multicolumn{2}{|c|}{$\begin{array}{l}\text { Previous } \\
52 \text { weeks }\end{array}$} & \multirow{2}{*}{$\begin{array}{l}\text { Cum } \\
2009 \\
\end{array}$} & \multirow{2}{*}{$\begin{array}{l}\text { Cum } \\
2008 \\
\end{array}$} & \multirow{2}{*}{$\begin{array}{c}\text { Current } \\
\text { week }\end{array}$} & \multicolumn{2}{|c|}{$\begin{array}{l}\text { Previous } \\
52 \text { weeks }\end{array}$} & \multirow{2}{*}{$\begin{array}{l}\text { Cum } \\
2009 \\
\end{array}$} & \multirow{2}{*}{$\begin{array}{l}\text { Cum } \\
2008 \\
\end{array}$} & \multirow{2}{*}{$\begin{array}{c}\text { Current } \\
\text { week }\end{array}$} & \multicolumn{2}{|c|}{$\begin{array}{l}\text { Previous } \\
52 \text { weeks }\end{array}$} & \multirow{2}{*}{$\begin{array}{l}\text { Cum } \\
2009 \\
\end{array}$} & \multirow{2}{*}{$\begin{array}{l}\text { Cum } \\
2008 \\
\end{array}$} \\
\hline & & Med & Max & & & & Med & Max & & & & Med & Max & & \\
\hline United States & 101 & 530 & 1,859 & 2,938 & 4,366 & 6 & 23 & 46 & 332 & 329 & 10 & 18 & 47 & 413 & 594 \\
\hline $\begin{array}{l}\text { New England } \\
\text { Connecticut } \\
\text { Maine } \\
\text { Massachusetts } \\
\text { New Hampshire } \\
\text { Rhode Island\$ } \\
\text { Vermont } \$\end{array}$ & $\begin{array}{l}\frac{12}{12} \\
\frac{-}{-} \\
=\end{array}$ & $\begin{array}{r}112 \\
35 \\
5 \\
26 \\
12 \\
0 \\
4\end{array}$ & $\begin{array}{r}834 \\
264 \\
73 \\
400 \\
145 \\
78 \\
41\end{array}$ & $\begin{array}{r}350 \\
75 \\
117 \\
112 \\
7 \\
39\end{array}$ & $\begin{array}{r}1,581 \\
687 \\
49 \\
539 \\
187 \\
101 \\
18\end{array}$ & $\begin{array}{l}= \\
= \\
= \\
=\end{array}$ & $\begin{array}{l}1 \\
0 \\
0 \\
0 \\
0 \\
0 \\
0\end{array}$ & $\begin{array}{l}6 \\
4 \\
0 \\
4 \\
1 \\
1 \\
1\end{array}$ & $\begin{array}{l}8 \\
1 \\
\frac{6}{6} \\
-1\end{array}$ & $\begin{array}{l}\frac{12}{1} \\
1 \\
8 \\
1 \\
1 \\
1\end{array}$ & $\begin{array}{l}= \\
= \\
= \\
=\end{array}$ & $\begin{array}{l}0 \\
0 \\
0 \\
0 \\
0 \\
0 \\
0\end{array}$ & $\begin{array}{l}4 \\
1 \\
1 \\
3 \\
1 \\
1 \\
1\end{array}$ & $\begin{array}{r}15 \\
1 \\
2 \\
9 \\
1 \\
1 \\
1\end{array}$ & $\begin{array}{r}17 \\
1 \\
3 \\
12 \\
1 \\
- \\
-\end{array}$ \\
\hline $\begin{array}{l}\text { Mid. Atlantic } \\
\text { New Jersey } \\
\text { New York (Upstate) } \\
\text { New York City } \\
\text { Pennsylvania }\end{array}$ & $\frac{\frac{63}{51}}{\frac{12}{12}}$ & $\begin{array}{r}229 \\
31 \\
99 \\
10 \\
50\end{array}$ & $\begin{array}{r}1,401 \\
231 \\
1,368 \\
54 \\
338\end{array}$ & $\begin{array}{r}1,599 \\
297 \\
621 \\
-681\end{array}$ & $\begin{array}{r}1,645 \\
781 \\
309 \\
121 \\
434\end{array}$ & $\begin{array}{l}= \\
\bar{z} \\
\end{array}$ & $\begin{array}{l}6 \\
0 \\
0 \\
3 \\
1\end{array}$ & $\begin{array}{r}17 \\
4 \\
10 \\
11 \\
3\end{array}$ & $\begin{array}{l}74 \\
17 \\
43 \\
14\end{array}$ & $\begin{array}{l}79 \\
13 \\
10 \\
45 \\
11\end{array}$ & $\begin{array}{l}\frac{1}{-} \\
\overline{1}\end{array}$ & $\begin{array}{l}2 \\
0 \\
0 \\
0 \\
1\end{array}$ & $\begin{array}{l}5 \\
1 \\
2 \\
2 \\
4\end{array}$ & $\begin{array}{r}44 \\
2 \\
10 \\
8 \\
24\end{array}$ & $\begin{array}{r}64 \\
9 \\
17 \\
10 \\
28\end{array}$ \\
\hline $\begin{array}{l}\text { E.N. Central } \\
\text { Illinois } \\
\text { Indiana } \\
\text { Michigan } \\
\text { Ohio } \\
\text { Wisconsin }\end{array}$ & $\begin{array}{l}\frac{1}{2} \\
\frac{1}{-} \\
-\end{array}$ & $\begin{array}{l}8 \\
0 \\
0 \\
1 \\
0 \\
5\end{array}$ & $\begin{array}{r}147 \\
13 \\
8 \\
10 \\
6 \\
6 \\
129\end{array}$ & $\begin{array}{r}\frac{86}{5} \\
9 \\
6 \\
66\end{array}$ & $\begin{array}{r}152 \\
7 \\
1 \\
-7 \\
137\end{array}$ & $\begin{array}{l}\frac{1}{-} \\
\frac{1}{-}\end{array}$ & $\begin{array}{l}2 \\
1 \\
0 \\
0 \\
1 \\
0\end{array}$ & $\begin{array}{l}7 \\
5 \\
1 \\
2 \\
2 \\
3\end{array}$ & $\begin{array}{r}39 \\
12 \\
6 \\
6 \\
14 \\
1\end{array}$ & $\begin{array}{r}54 \\
27 \\
3 \\
8 \\
13 \\
3\end{array}$ & $\begin{array}{l}1 \\
- \\
-1 \\
-\end{array}$ & $\begin{array}{l}3 \\
1 \\
0 \\
0 \\
0 \\
0\end{array}$ & $\begin{array}{l}8 \\
6 \\
4 \\
3 \\
3 \\
1\end{array}$ & $\begin{array}{r}65 \\
13 \\
14 \\
12 \\
20 \\
6\end{array}$ & $\begin{array}{l}97 \\
34 \\
13 \\
14 \\
24 \\
12\end{array}$ \\
\hline $\begin{array}{l}\text { W.N. Central } \\
\text { lowa } \\
\text { Kansas } \\
\text { Minnesota } \\
\text { Missouri } \\
\text { Nebraska } \\
\text { North Dakota } \\
\text { South Dakota }\end{array}$ & $\begin{array}{l}= \\
= \\
= \\
=\end{array}$ & $\begin{array}{l}7 \\
1 \\
0 \\
4 \\
0 \\
0 \\
0 \\
0\end{array}$ & $\begin{array}{r}336 \\
9 \\
4 \\
326 \\
1 \\
2 \\
10 \\
1\end{array}$ & $\begin{array}{r}39 \\
5 \\
5 \\
28 \\
- \\
- \\
1\end{array}$ & $\begin{array}{r}87 \\
25 \\
3 \\
56 \\
1 \\
1 \\
-1\end{array}$ & $\begin{array}{l}\frac{1}{z} \\
\overline{1} \\
- \\
-\end{array}$ & $\begin{array}{l}1 \\
0 \\
0 \\
0 \\
0 \\
0 \\
0 \\
0\end{array}$ & $\begin{array}{r}10 \\
3 \\
2 \\
8 \\
2 \\
1 \\
0 \\
1\end{array}$ & $\begin{array}{r}19 \\
4 \\
1 \\
9 \\
4 \\
- \\
1\end{array}$ & $\begin{array}{r}20 \\
2 \\
3 \\
6 \\
5 \\
4 \\
-\end{array}$ & $\begin{array}{l}\frac{2}{z} \\
\overline{2} \\
\frac{2}{-}\end{array}$ & $\begin{array}{l}1 \\
0 \\
0 \\
0 \\
0 \\
0 \\
0 \\
0\end{array}$ & $\begin{array}{l}9 \\
1 \\
2 \\
4 \\
2 \\
1 \\
3 \\
1\end{array}$ & $\begin{array}{r}35 \\
2 \\
7 \\
8 \\
13 \\
3 \\
2\end{array}$ & $\begin{array}{r}55 \\
11 \\
2 \\
15 \\
16 \\
9 \\
1 \\
1\end{array}$ \\
\hline $\begin{array}{l}\text { S. Atlantic } \\
\text { Delaware } \\
\text { District of Columbia } \\
\text { Florida } \\
\text { Georgia } \\
\text { Maryland\$ } \\
\text { North Carolina } \\
\text { South Carolina } \\
\text { Virginia } \\
\text { West Virginia }\end{array}$ & $\begin{array}{r}18 \\
\frac{4}{2} \\
\frac{7}{7} \\
\frac{5}{5}\end{array}$ & $\begin{array}{r}70 \\
11 \\
1 \\
1 \\
0 \\
29 \\
1 \\
0 \\
14 \\
1\end{array}$ & $\begin{array}{r}225 \\
36 \\
7 \\
6 \\
6 \\
165 \\
6 \\
2 \\
61 \\
17\end{array}$ & $\begin{array}{r}759 \\
167 \\
14 \\
15 \\
381 \\
16 \\
8 \\
124 \\
34\end{array}$ & $\begin{array}{r}817 \\
242 \\
13 \\
12 \\
10 \\
412 \\
2 \\
8 \\
93 \\
25\end{array}$ & $\begin{array}{l}3 \\
- \\
1 \\
1 \\
1 \\
= \\
=\end{array}$ & $\begin{array}{l}7 \\
0 \\
0 \\
1 \\
1 \\
2 \\
1 \\
0 \\
1 \\
0\end{array}$ & $\begin{array}{r}16 \\
1 \\
2 \\
7 \\
4 \\
8 \\
7 \\
1 \\
3 \\
1\end{array}$ & $\begin{array}{r}126 \\
1 \\
34 \\
26 \\
33 \\
17 \\
1 \\
13 \\
1\end{array}$ & $\begin{array}{r}85 \\
1 \\
20 \\
24 \\
26 \\
2 \\
2 \\
9 \\
1\end{array}$ & $\begin{array}{l}\frac{2}{-} \\
\frac{1}{-} \\
\frac{1}{-} \\
=\end{array}$ & $\begin{array}{l}3 \\
0 \\
0 \\
1 \\
0 \\
0 \\
0 \\
0 \\
0 \\
0\end{array}$ & $\begin{array}{l}9 \\
1 \\
0 \\
4 \\
2 \\
3 \\
5 \\
1 \\
2 \\
2\end{array}$ & $\begin{array}{r}77 \\
1 \\
29 \\
12 \\
4 \\
15 \\
5 \\
7 \\
4\end{array}$ & $\begin{array}{r}73 \\
\overline{2} \\
27 \\
8 \\
6 \\
3 \\
14 \\
13 \\
2\end{array}$ \\
\hline $\begin{array}{l}\text { E.S. Central } \\
\text { Alabama } \$ \\
\text { Kentucky } \\
\text { Mississippi } \\
\text { Tennessee§ }\end{array}$ & $\begin{array}{l}z \\
\bar{z} \\
=\end{array}$ & $\begin{array}{l}0 \\
0 \\
0 \\
0 \\
0\end{array}$ & $\begin{array}{l}5 \\
1 \\
2 \\
1 \\
3\end{array}$ & $\begin{array}{l}6 \\
1 \\
- \\
5\end{array}$ & $\begin{array}{r}13 \\
6 \\
1 \\
-6\end{array}$ & $\begin{array}{l}- \\
\overline{-} \\
-\end{array}$ & $\begin{array}{l}0 \\
0 \\
0 \\
0 \\
0\end{array}$ & $\begin{array}{l}2 \\
1 \\
2 \\
1 \\
2\end{array}$ & $\begin{array}{r}11 \\
3 \\
4 \\
-4\end{array}$ & $\begin{array}{l}7 \\
3 \\
2 \\
2\end{array}$ & $\begin{array}{l}= \\
= \\
z\end{array}$ & $\begin{array}{l}0 \\
0 \\
0 \\
0 \\
0\end{array}$ & $\begin{array}{l}3 \\
1 \\
1 \\
1 \\
1\end{array}$ & $\begin{array}{r}15 \\
3 \\
3 \\
1 \\
8\end{array}$ & $\begin{array}{r}35 \\
3 \\
7 \\
9 \\
16\end{array}$ \\
\hline $\begin{array}{l}\text { W.S. Central } \\
\text { Arkansas§ } \\
\text { Louisiana } \\
\text { Oklahoma } \\
\text { Texas§ }\end{array}$ & $\frac{1}{-}$ & $\begin{array}{l}2 \\
0 \\
0 \\
0 \\
2\end{array}$ & $\begin{array}{r}21 \\
0 \\
1 \\
1 \\
21\end{array}$ & $\frac{10}{\frac{1}{10}}$ & $\begin{array}{l}\frac{30}{-} \\
\frac{-}{30}\end{array}$ & $\begin{array}{l}= \\
\bar{z} \\
-\end{array}$ & $\begin{array}{l}1 \\
0 \\
0 \\
0 \\
1\end{array}$ & $\begin{array}{r}10 \\
1 \\
1 \\
2 \\
10\end{array}$ & $\frac{8}{\frac{1}{7}}$ & $\begin{array}{r}\frac{16}{1} \\
1 \\
14\end{array}$ & $\begin{array}{l}= \\
= \\
-\end{array}$ & $\begin{array}{l}2 \\
0 \\
0 \\
0 \\
1\end{array}$ & $\begin{array}{r}11 \\
2 \\
3 \\
3 \\
9\end{array}$ & $\begin{array}{r}36 \\
5 \\
9 \\
2 \\
20\end{array}$ & $\begin{array}{r}64 \\
9 \\
17 \\
8 \\
30\end{array}$ \\
\hline $\begin{array}{l}\text { Mountain } \\
\text { Arizona } \\
\text { Colorado } \\
\text { Idaho§ } \\
\text { Montana§ } \\
\text { Nevada§ } \\
\text { New Mexico§ } \\
\text { Utah } \\
\text { Wyoming§ }\end{array}$ & $\begin{array}{l}-1 \\
- \\
- \\
- \\
-\end{array}$ & $\begin{array}{l}1 \\
0 \\
0 \\
0 \\
0 \\
0 \\
0 \\
0 \\
0\end{array}$ & $\begin{array}{r}13 \\
2 \\
1 \\
1 \\
13 \\
2 \\
2 \\
1 \\
1\end{array}$ & $\begin{array}{r}11 \\
1 \\
2 \\
3 \\
1 \\
4 \\
- \\
-\end{array}$ & $\begin{array}{l}6 \\
2 \\
2 \\
1 \\
- \\
-1 \\
-\end{array}$ & $\begin{array}{l}= \\
= \\
= \\
z \\
=\end{array}$ & $\begin{array}{l}0 \\
0 \\
0 \\
0 \\
0 \\
0 \\
0 \\
0 \\
0\end{array}$ & $\begin{array}{l}3 \\
2 \\
1 \\
1 \\
0 \\
1 \\
1 \\
1 \\
0\end{array}$ & $\begin{array}{l}3 \\
1 \\
1 \\
- \\
- \\
- \\
-1 \\
-\end{array}$ & $\begin{array}{r}10 \\
3 \\
3 \\
- \\
-4 \\
- \\
-\end{array}$ & $\begin{array}{l}= \\
= \\
= \\
= \\
= \\
=\end{array}$ & $\begin{array}{l}1 \\
0 \\
0 \\
0 \\
0 \\
0 \\
0 \\
0 \\
0\end{array}$ & $\begin{array}{l}4 \\
2 \\
2 \\
1 \\
1 \\
2 \\
1 \\
1 \\
2\end{array}$ & $\begin{array}{r}33 \\
7 \\
10 \\
4 \\
2 \\
3 \\
3 \\
1 \\
3\end{array}$ & $\begin{array}{r}32 \\
2 \\
6 \\
4 \\
4 \\
6 \\
4 \\
4 \\
2\end{array}$ \\
\hline $\begin{array}{l}\text { Pacific } \\
\text { Alaska } \\
\text { California } \\
\text { Hawaii } \\
\text { Oregon } \$ \\
\text { Washington }\end{array}$ & $\begin{array}{l}\frac{5}{4} \\
\frac{\mathrm{N}}{1}\end{array}$ & $\begin{array}{l}3 \\
0 \\
2 \\
0 \\
0 \\
0\end{array}$ & $\begin{array}{r}13 \\
2 \\
6 \\
0 \\
6 \\
12\end{array}$ & $\begin{array}{r}78 \\
1 \\
66 \\
N \\
9 \\
2\end{array}$ & $\begin{array}{l}\frac{35}{25} \\
\mathrm{~N} \\
10 \\
-\end{array}$ & $\begin{array}{l}\frac{1}{-} \\
\frac{-}{1}\end{array}$ & $\begin{array}{l}3 \\
0 \\
2 \\
0 \\
0 \\
0\end{array}$ & $\begin{array}{r}10 \\
1 \\
8 \\
1 \\
4 \\
3\end{array}$ & $\begin{array}{r}44 \\
1 \\
32 \\
1 \\
5 \\
5\end{array}$ & $\begin{array}{r}46 \\
2 \\
35 \\
2 \\
4 \\
3\end{array}$ & $\begin{array}{l}\frac{4}{4} \\
- \\
-\end{array}$ & $\begin{array}{l}4 \\
0 \\
2 \\
0 \\
0 \\
0\end{array}$ & $\begin{array}{r}14 \\
2 \\
8 \\
1 \\
9 \\
6\end{array}$ & $\begin{array}{r}93 \\
2 \\
56 \\
3 \\
23 \\
9\end{array}$ & $\begin{array}{r}157 \\
2 \\
123 \\
1 \\
18 \\
13\end{array}$ \\
\hline $\begin{array}{l}\text { American Samoa } \\
\text { C.N.M.I. } \\
\text { Guam } \\
\text { Puerto Rico } \\
\text { U.S. Virgin Islands }\end{array}$ & $\begin{array}{l}\frac{\mathrm{N}}{-} \\
\overline{\mathrm{N}} \\
\mathrm{N}\end{array}$ & $\begin{array}{l}0 \\
0 \\
0 \\
0\end{array}$ & $\begin{array}{l}0 \\
0 \\
0 \\
0\end{array}$ & $\begin{array}{l}\mathrm{N} \\
\mathrm{N} \\
\mathrm{N}\end{array}$ & $\begin{array}{l}\frac{N}{-} \\
N \\
N\end{array}$ & $\begin{array}{l}- \\
\overline{-} \\
-\end{array}$ & $\begin{array}{l}0 \\
0 \\
0 \\
0\end{array}$ & $\begin{array}{c}0 \\
2 \\
1 \\
0\end{array}$ & $\begin{array}{l}\overline{-} \\
\overline{1} \\
-\end{array}$ & $\begin{array}{l}\bar{z} \\
\frac{1}{1}\end{array}$ & $\begin{array}{l}z \\
z \\
-\end{array}$ & $\begin{array}{c}0 \\
0 \\
0 \\
0\end{array}$ & $\begin{array}{c}0 \\
0 \\
1 \\
0\end{array}$ & $\begin{array}{l}z \\
z \\
-\end{array}$ & $\begin{array}{c}- \\
\frac{2}{2}\end{array}$ \\
\hline
\end{tabular}

C.N.M.I.: Commonwealth of Northern Mariana Islands.

U: Unavailable. - - No reported cases. N: Not notifiable. Cum: Cumulative year-to-date counts. Med: Median. Max: Maximum.

* Incidence data for reporting year 2008 and 2009 are provisional.

† Data for meningococcal disease, invasive caused by serogroups A, C, Y, and W-135; serogroup B; other serogroup; and unknown serogroup are available in Table I.

$\S$ Contains data reported through the National Electronic Disease Surveillance System (NEDSS). 
TABLE II. (Continued) Provisional cases of selected notifiable diseases, United States, weeks ending May 30, 2009, and May 24, 2008 (21st week)*

\begin{tabular}{|c|c|c|c|c|c|c|c|c|c|c|c|c|c|c|c|}
\hline \multirow[b]{3}{*}{ Reporting area } & \multicolumn{5}{|c|}{ Pertussis } & \multicolumn{5}{|c|}{ Rabies, animal } & \multicolumn{5}{|c|}{ Rocky Mountain spotted fever } \\
\hline & \multirow{2}{*}{$\begin{array}{c}\text { Current } \\
\text { week }\end{array}$} & \multicolumn{2}{|c|}{$\begin{array}{l}\text { Previous } \\
52 \text { weeks }\end{array}$} & \multirow{2}{*}{$\begin{array}{l}\text { Cum } \\
2009 \\
\end{array}$} & \multirow{2}{*}{$\begin{array}{l}\text { Cum } \\
2008\end{array}$} & \multirow{2}{*}{$\begin{array}{c}\text { Current } \\
\text { week }\end{array}$} & \multicolumn{2}{|c|}{$\begin{array}{l}\text { Previous } \\
52 \text { weeks }\end{array}$} & \multirow{2}{*}{$\begin{array}{l}\text { Cum } \\
2009\end{array}$} & \multirow{2}{*}{$\begin{array}{l}\text { Cum } \\
2008\end{array}$} & \multirow{2}{*}{$\begin{array}{c}\text { Current } \\
\text { week }\end{array}$} & \multicolumn{2}{|c|}{$\begin{array}{l}\text { Previous } \\
52 \text { weeks }\end{array}$} & \multirow{2}{*}{$\begin{array}{l}\text { Cum } \\
2009\end{array}$} & \multirow{2}{*}{$\begin{array}{l}\text { Cum } \\
2008 \\
\end{array}$} \\
\hline & & Med & Max & & & & Med & Max & & & & Med & $\operatorname{Max}$ & & \\
\hline United States & 75 & 235 & 1,691 & 4,339 & 3,039 & 23 & 70 & 120 & 1,216 & 1,523 & 11 & 39 & 152 & 330 & 193 \\
\hline $\begin{array}{l}\text { New England } \\
\text { Connecticut } \\
\text { Maine }^{\dagger} \\
\text { Massachusetts } \\
\text { New Hampshire } \\
\text { Rhode Island }^{\dagger} \\
\text { Vermont }^{\dagger}\end{array}$ & $\begin{array}{l}\frac{1}{1} \\
- \\
- \\
-\end{array}$ & $\begin{array}{r}18 \\
0 \\
1 \\
12 \\
1 \\
0 \\
0\end{array}$ & $\begin{array}{r}35 \\
4 \\
7 \\
30 \\
5 \\
6 \\
2\end{array}$ & $\begin{array}{r}175 \\
6 \\
34 \\
105 \\
21 \\
3 \\
6\end{array}$ & $\begin{array}{r}365 \\
26 \\
13 \\
287 \\
9 \\
25 \\
5\end{array}$ & $\begin{array}{l}- \\
- \\
- \\
-\end{array}$ & $\begin{array}{l}8 \\
3 \\
1 \\
0 \\
1 \\
0 \\
1\end{array}$ & $\begin{array}{r}21 \\
17 \\
5 \\
0 \\
7 \\
3 \\
6\end{array}$ & $\begin{array}{r}114 \\
49 \\
20 \\
13 \\
8 \\
24\end{array}$ & $\begin{array}{r}138 \\
62 \\
26 \\
14 \\
10 \\
26\end{array}$ & $\begin{array}{l}\frac{1}{1} \\
- \\
- \\
-\end{array}$ & $\begin{array}{l}0 \\
0 \\
0 \\
0 \\
0 \\
0 \\
0\end{array}$ & $\begin{array}{l}2 \\
0 \\
2 \\
1 \\
1 \\
2 \\
0\end{array}$ & $\begin{array}{l}\frac{4}{4} \\
- \\
-\end{array}$ & $\begin{array}{l}\frac{2}{-} \\
\frac{1}{1} \\
-\end{array}$ \\
\hline $\begin{array}{l}\text { Mid. Atlantic } \\
\text { New Jersey } \\
\text { New York (Upstate) } \\
\text { New York City } \\
\text { Pennsylvania }\end{array}$ & $\begin{array}{l}\frac{15}{1} \\
7 \\
7\end{array}$ & $\begin{array}{r}24 \\
3 \\
6 \\
0 \\
10\end{array}$ & $\begin{array}{l}64 \\
12 \\
41 \\
21 \\
33\end{array}$ & $\begin{array}{r}382 \\
26 \\
74 \\
40 \\
242\end{array}$ & $\begin{array}{r}354 \\
59 \\
107 \\
38 \\
150\end{array}$ & $\begin{array}{l}\frac{7}{7} \\
- \\
-\end{array}$ & $\begin{array}{r}18 \\
0 \\
9 \\
0 \\
7\end{array}$ & $\begin{array}{r}30 \\
0 \\
20 \\
2 \\
17\end{array}$ & $\frac{254}{136}$ & $\begin{array}{r}296 \\
144 \\
8 \\
144\end{array}$ & $\begin{array}{l}- \\
- \\
-\end{array}$ & $\begin{array}{l}1 \\
0 \\
0 \\
0 \\
0\end{array}$ & $\begin{array}{r}29 \\
6 \\
29 \\
2 \\
2\end{array}$ & $\begin{array}{l}9 \\
1 \\
6 \\
2\end{array}$ & $\begin{array}{r}32 \\
21 \\
3 \\
5 \\
3\end{array}$ \\
\hline $\begin{array}{l}\text { E.N. Central } \\
\text { Illinois } \\
\text { Indiana } \\
\text { Michigan } \\
\text { Ohio } \\
\text { Wisconsin }\end{array}$ & $\begin{array}{l}\frac{15}{-} \\
2 \\
13 \\
-\end{array}$ & $\begin{array}{r}37 \\
14 \\
2 \\
8 \\
14 \\
2\end{array}$ & $\begin{array}{r}238 \\
45 \\
158 \\
21 \\
57 \\
7\end{array}$ & $\begin{array}{r}859 \\
173 \\
76 \\
195 \\
383 \\
32\end{array}$ & $\begin{array}{r}625 \\
60 \\
20 \\
77 \\
436 \\
32\end{array}$ & $\begin{array}{l}4 \\
- \\
1 \\
3 \\
\mathrm{~N}\end{array}$ & $\begin{array}{l}2 \\
1 \\
0 \\
1 \\
0 \\
0\end{array}$ & $\begin{array}{r}28 \\
20 \\
2 \\
9 \\
7 \\
0\end{array}$ & $\begin{array}{r}25 \\
6 \\
14 \\
5 \\
\mathrm{~N}\end{array}$ & $\begin{array}{r}31 \\
8 \\
1 \\
17 \\
5 \\
\mathrm{~N}\end{array}$ & $\begin{array}{l}- \\
- \\
- \\
-\end{array}$ & $\begin{array}{l}2 \\
1 \\
0 \\
0 \\
0 \\
0\end{array}$ & $\begin{array}{r}15 \\
10 \\
3 \\
1 \\
4 \\
1\end{array}$ & $\begin{array}{r}10 \\
6 \\
-1 \\
3 \\
-\end{array}$ & $\begin{array}{r}10 \\
9 \\
- \\
-1 \\
-\end{array}$ \\
\hline $\begin{array}{l}\text { W.N. Central } \\
\text { lowa } \\
\text { Kansas } \\
\text { Minnesota } \\
\text { Missouri } \\
\text { Nebraska }{ }^{\dagger} \\
\text { North Dakota } \\
\text { South Dakota }\end{array}$ & $\begin{array}{l}-8 \\
- \\
5 \\
- \\
-\end{array}$ & $\begin{array}{r}31 \\
4 \\
2 \\
0 \\
14 \\
4 \\
0 \\
0\end{array}$ & $\begin{array}{r}872 \\
21 \\
12 \\
808 \\
51 \\
32 \\
24 \\
10\end{array}$ & $\begin{array}{r}848 \\
47 \\
76 \\
160 \\
476 \\
77 \\
2 \\
10\end{array}$ & $\begin{array}{r}236 \\
34 \\
26 \\
49 \\
99 \\
18 \\
10\end{array}$ & $\begin{array}{l}1 \\
- \\
- \\
- \\
-\end{array}$ & $\begin{array}{l}5 \\
0 \\
1 \\
0 \\
1 \\
0 \\
0 \\
0\end{array}$ & $\begin{array}{r}17 \\
5 \\
6 \\
11 \\
8 \\
2 \\
9 \\
4\end{array}$ & $\begin{array}{r}97 \\
9 \\
37 \\
18 \\
17 \\
3 \\
13\end{array}$ & $\begin{array}{r}95 \\
8 \\
34 \\
16 \\
6 \\
15 \\
8 \\
8\end{array}$ & $\begin{array}{l}3 \\
- \\
- \\
- \\
-\end{array}$ & $\begin{array}{l}4 \\
0 \\
0 \\
0 \\
4 \\
0 \\
0 \\
0\end{array}$ & $\begin{array}{r}33 \\
2 \\
0 \\
0 \\
32 \\
4 \\
1 \\
1\end{array}$ & $\begin{array}{l}42 \\
- \\
- \\
41 \\
1 \\
-\end{array}$ & $\begin{array}{r}36 \\
1 \\
- \\
-33 \\
- \\
2\end{array}$ \\
\hline $\begin{array}{l}\text { S. Atlantic } \\
\text { Delaware } \\
\text { District of Columbia } \\
\text { Florida } \\
\text { Georgia } \\
\text { Maryland }^{\dagger} \\
\text { North Carolina }^{\text {South Carolina }}{ }^{\dagger} \\
\text { Virginia }^{\dagger} \\
\text { West Virginia }^{\text {West }}\end{array}$ & $\begin{array}{l}\frac{19}{-} \\
\frac{16}{-} \\
\overline{1} \\
\frac{2}{-}\end{array}$ & $\begin{array}{r}25 \\
0 \\
0 \\
7 \\
3 \\
3 \\
0 \\
2 \\
3 \\
0\end{array}$ & $\begin{array}{r}71 \\
3 \\
2 \\
20 \\
9 \\
10 \\
65 \\
10 \\
24 \\
2\end{array}$ & $\begin{array}{r}580 \\
6 \\
198 \\
79 \\
36 \\
153 \\
55 \\
48 \\
5\end{array}$ & $\begin{array}{r}284 \\
4 \\
1 \\
65 \\
21 \\
43 \\
59 \\
42 \\
44 \\
5\end{array}$ & $\begin{array}{l}- \\
- \\
- \\
\bar{N} \\
- \\
-\end{array}$ & $\begin{array}{r}27 \\
0 \\
0 \\
0 \\
5 \\
7 \\
4 \\
0 \\
11 \\
1\end{array}$ & $\begin{array}{r}66 \\
0 \\
0 \\
22 \\
47 \\
16 \\
4 \\
0 \\
24 \\
6\end{array}$ & $\begin{array}{r}530 \\
- \\
54 \\
102 \\
130 \\
\mathrm{~N} \\
205 \\
39\end{array}$ & $\begin{array}{r}767 \\
- \\
138 \\
167 \\
186 \\
\mathrm{~N} \\
- \\
227 \\
49\end{array}$ & $\begin{array}{l}\frac{7}{-} \\
\frac{2}{-} \\
\frac{3}{2} \\
-\end{array}$ & $\begin{array}{r}16 \\
0 \\
0 \\
0 \\
1 \\
1 \\
9 \\
1 \\
2 \\
0\end{array}$ & $\begin{array}{r}72 \\
5 \\
1 \\
3 \\
9 \\
7 \\
55 \\
9 \\
15 \\
1\end{array}$ & $\begin{array}{r}194 \\
3 \\
- \\
4 \\
9 \\
16 \\
136 \\
9 \\
16 \\
1\end{array}$ & $\begin{array}{r}59 \\
3 \\
1 \\
3 \\
13 \\
12 \\
11 \\
5 \\
8 \\
3\end{array}$ \\
\hline $\begin{array}{c}\text { E.S. Central } \\
\text { Alabama }^{\dagger} \\
\text { Kentucky } \\
\text { Mississippi } \\
\text { Tennessee }^{\dagger}\end{array}$ & $\begin{array}{l}2 \\
1 \\
- \\
1\end{array}$ & $\begin{array}{r}11 \\
2 \\
4 \\
1 \\
2\end{array}$ & $\begin{array}{r}33 \\
18 \\
15 \\
5 \\
14\end{array}$ & $\begin{array}{r}254 \\
88 \\
91 \\
17 \\
58\end{array}$ & $\begin{array}{l}95 \\
19 \\
14 \\
41 \\
21\end{array}$ & $\begin{array}{l}- \\
- \\
-\end{array}$ & $\begin{array}{l}3 \\
0 \\
1 \\
0 \\
2\end{array}$ & $\begin{array}{l}7 \\
0 \\
4 \\
1 \\
6\end{array}$ & $\frac{58}{\frac{24}{34}}$ & $\begin{array}{r}69 \\
13 \\
1 \\
55\end{array}$ & $\begin{array}{l}- \\
- \\
-\end{array}$ & $\begin{array}{l}4 \\
1 \\
0 \\
0 \\
3\end{array}$ & $\begin{array}{r}23 \\
8 \\
1 \\
3 \\
19\end{array}$ & $\begin{array}{r}48 \\
9 \\
-1 \\
38\end{array}$ & $\begin{array}{r}31 \\
11 \\
3 \\
17\end{array}$ \\
\hline $\begin{array}{l}\text { W.S. Central } \\
\text { Arkansas }^{\dagger} \\
\text { Louisiana } \\
\text { Oklahoma } \\
\text { Texas }^{\dagger}\end{array}$ & $\frac{1}{-}$ & $\begin{array}{r}40 \\
2 \\
2 \\
0 \\
35\end{array}$ & $\begin{array}{r}384 \\
38 \\
7 \\
40 \\
304\end{array}$ & $\begin{array}{r}671 \\
30 \\
34 \\
12 \\
595\end{array}$ & $\begin{array}{r}282 \\
31 \\
8 \\
7 \\
236\end{array}$ & $\begin{array}{r}4 \\
4 \\
- \\
- \\
-\end{array}$ & $\begin{array}{l}0 \\
0 \\
0 \\
0 \\
0\end{array}$ & $\begin{array}{l}9 \\
6 \\
0 \\
9 \\
1\end{array}$ & $\begin{array}{l}21 \\
16 \\
4 \\
1\end{array}$ & $\begin{array}{r}41 \\
24 \\
16 \\
1\end{array}$ & $\begin{array}{l}- \\
- \\
-\end{array}$ & $\begin{array}{l}2 \\
0 \\
0 \\
0 \\
1\end{array}$ & $\begin{array}{r}134 \\
61 \\
2 \\
71 \\
6\end{array}$ & $\begin{array}{r}16 \\
3 \\
-3 \\
10\end{array}$ & $\begin{array}{r}14 \\
1 \\
2 \\
4 \\
7\end{array}$ \\
\hline $\begin{array}{l}\text { Mountain } \\
\text { Arizona } \\
\text { Colorado } \\
\text { Idaho }^{\dagger} \\
\text { Montana }^{\dagger} \\
\text { Nevada }^{\dagger} \\
\text { New Mexico }^{\dagger} \\
\text { Utah } \\
\text { Wyoming } \\
\text { Wy }\end{array}$ & $\begin{array}{l}9 \\
8 \\
1 \\
- \\
- \\
-\end{array}$ & $\begin{array}{r}14 \\
2 \\
4 \\
1 \\
0 \\
0 \\
1 \\
4 \\
0\end{array}$ & $\begin{array}{r}31 \\
10 \\
12 \\
5 \\
4 \\
3 \\
10 \\
19 \\
2\end{array}$ & $\begin{array}{r}312 \\
51 \\
111 \\
35 \\
9 \\
6 \\
29 \\
70 \\
1\end{array}$ & $\begin{array}{r}404 \\
112 \\
61 \\
20 \\
58 \\
15 \\
23 \\
109 \\
6\end{array}$ & $\begin{array}{l}\bar{N} \\
- \\
- \\
- \\
- \\
-\end{array}$ & $\begin{array}{l}2 \\
0 \\
0 \\
0 \\
0 \\
0 \\
0 \\
0 \\
0\end{array}$ & $\begin{array}{l}9 \\
0 \\
0 \\
2 \\
4 \\
5 \\
2 \\
6 \\
4\end{array}$ & $\begin{array}{r}37 \\
\mathrm{~N} \\
- \\
11 \\
14 \\
1 \\
11\end{array}$ & $\begin{array}{r}21 \\
\mathrm{~N} \\
- \\
- \\
1 \\
14 \\
1 \\
5\end{array}$ & $\begin{array}{l}- \\
- \\
- \\
- \\
- \\
-\end{array}$ & $\begin{array}{l}1 \\
0 \\
0 \\
0 \\
0 \\
0 \\
0 \\
0 \\
0\end{array}$ & $\begin{array}{l}3 \\
2 \\
1 \\
1 \\
1 \\
2 \\
1 \\
1 \\
2\end{array}$ & $\begin{array}{l}6 \\
1 \\
- \\
3 \\
-1 \\
1 \\
-\end{array}$ & $\begin{array}{l}8 \\
3 \\
- \\
1 \\
-1 \\
2 \\
1\end{array}$ \\
\hline $\begin{array}{l}\text { Pacific } \\
\text { Alaska } \\
\text { California } \\
\text { Hawaii } \\
\text { Oregon }{ }^{\dagger} \\
\text { Washington }\end{array}$ & $\frac{5}{\frac{5}{1}}$ & $\begin{array}{r}24 \\
3 \\
6 \\
0 \\
3 \\
6\end{array}$ & $\begin{array}{r}98 \\
21 \\
24 \\
3 \\
42 \\
76\end{array}$ & $\begin{array}{r}258 \\
28 \\
22 \\
12 \\
88 \\
108\end{array}$ & $\begin{array}{r}394 \\
34 \\
193 \\
5 \\
59 \\
103\end{array}$ & $\begin{array}{l}\frac{7}{7} \\
- \\
- \\
-\end{array}$ & $\begin{array}{l}4 \\
0 \\
3 \\
0 \\
0 \\
0\end{array}$ & $\begin{array}{r}13 \\
2 \\
12 \\
0 \\
2 \\
0\end{array}$ & $\begin{array}{r}80 \\
9 \\
71 \\
- \\
- \\
\end{array}$ & $\begin{array}{l}65 \\
12 \\
52 \\
-1 \\
-\end{array}$ & $\begin{array}{l}\frac{\bar{N}}{\mathrm{~N}} \\
\frac{-}{-}\end{array}$ & $\begin{array}{l}0 \\
0 \\
0 \\
0 \\
0 \\
0\end{array}$ & $\begin{array}{l}1 \\
0 \\
1 \\
0 \\
1 \\
0\end{array}$ & $\begin{array}{r}1 \\
N \\
1 \\
N \\
- \\
-\end{array}$ & $\begin{array}{l}1 \\
\mathrm{~N} \\
\mathrm{~N} \\
1 \\
-\end{array}$ \\
\hline $\begin{array}{l}\text { American Samoa } \\
\text { C.N.M.I. } \\
\text { Guam } \\
\text { Puerto Rico } \\
\text { U.S. Virgin Islands }\end{array}$ & $\begin{array}{l}- \\
- \\
-\end{array}$ & $\begin{array}{l}0 \\
0 \\
0 \\
0\end{array}$ & $\begin{array}{l}0 \\
0 \\
1 \\
0\end{array}$ & $\begin{array}{l}- \\
- \\
1\end{array}$ & $\begin{array}{l}- \\
- \\
-\end{array}$ & $\frac{\mathrm{N}}{-}$ & $\begin{array}{l}0 \\
0 \\
1 \\
0\end{array}$ & $\begin{array}{l}0 \\
0 \\
5 \\
0\end{array}$ & $\begin{array}{r}\frac{N}{-} \\
15 \\
N\end{array}$ & $\frac{\mathrm{N}}{-}$ & $\begin{array}{l}\mathrm{N} \\
\mathrm{N} \\
\mathrm{N} \\
\mathrm{N}\end{array}$ & $\begin{array}{l}0 \\
0 \\
0 \\
0\end{array}$ & $\begin{array}{l}0 \\
0 \\
0 \\
0\end{array}$ & $\begin{array}{l}\mathrm{N} \\
\mathrm{N} \\
\mathrm{N} \\
\mathrm{N}\end{array}$ & $\begin{array}{l}\mathrm{N} \\
\mathrm{N} \\
\mathrm{N} \\
\mathrm{N}\end{array}$ \\
\hline
\end{tabular}

C.N.M.I.: Commonwealth of Northern Mariana Islands.

U: Unavailable. - No reported cases. N: Not notifiable. Cum: Cumulative year-to-date counts. Med: Median. Max: Maximum.

* Incidence data for reporting year 2008 and 2009 are provisional.

† Contains data reported through the National Electronic Disease Surveillance System (NEDSS). 
TABLE II. (Continued) Provisional cases of selected notifiable diseases, United States, weeks ending May 30, 2009, and May 24, 2008 (21st week)*

\begin{tabular}{|c|c|c|c|c|c|c|c|c|c|c|c|c|c|c|c|}
\hline \multirow[b]{3}{*}{ Reporting area } & \multicolumn{5}{|c|}{ Salmonellosis } & \multicolumn{5}{|c|}{ Shiga toxin-producing $E$. coli (STEC) ${ }^{\dagger}$} & \multicolumn{5}{|c|}{ Shigellosis } \\
\hline & \multirow{2}{*}{$\begin{array}{c}\text { Current } \\
\text { week }\end{array}$} & \multicolumn{2}{|c|}{$\begin{array}{l}\text { Previous } \\
52 \text { weeks }\end{array}$} & \multirow{2}{*}{$\begin{array}{l}\text { Cum } \\
2009\end{array}$} & \multirow{2}{*}{$\begin{array}{l}\text { Cum } \\
2008\end{array}$} & \multirow{2}{*}{$\begin{array}{c}\text { Current } \\
\text { week }\end{array}$} & \multicolumn{2}{|c|}{$\begin{array}{l}\text { Previous } \\
52 \text { weeks }\end{array}$} & \multirow{2}{*}{$\begin{array}{l}\text { Cum } \\
2009\end{array}$} & \multirow{2}{*}{$\begin{array}{l}\text { Cum } \\
2008\end{array}$} & \multirow{2}{*}{$\begin{array}{c}\text { Current } \\
\text { week }\end{array}$} & \multicolumn{2}{|c|}{$\begin{array}{l}\text { Previous } \\
52 \text { weeks }\end{array}$} & \multirow{2}{*}{$\begin{array}{l}\text { Cum } \\
2009\end{array}$} & \multirow{2}{*}{$\begin{array}{l}\text { Cum } \\
2008\end{array}$} \\
\hline & & Med & Max & & & & Med & Max & & & & Med & Max & & \\
\hline United States & 378 & 978 & 2,267 & 11,572 & 12,236 & 39 & 83 & 219 & 969 & 1,133 & 150 & 438 & 1,249 & 5,507 & 6,284 \\
\hline $\begin{array}{l}\text { New England } \\
\text { Connecticut } \\
\text { Maine§ } \\
\text { Massachusetts } \\
\text { New Hampshire } \\
\text { Rhode Island§ } \\
\text { Vermont } \$\end{array}$ & $\begin{array}{l}- \\
- \\
- \\
-\end{array}$ & $\begin{array}{r}33 \\
0 \\
2 \\
23 \\
3 \\
2 \\
1\end{array}$ & $\begin{array}{r}164 \\
138 \\
8 \\
51 \\
30 \\
9 \\
7\end{array}$ & $\begin{array}{r}599 \\
138 \\
38 \\
263 \\
97 \\
45 \\
18\end{array}$ & $\begin{array}{r}923 \\
491 \\
53 \\
295 \\
37 \\
26 \\
21\end{array}$ & $\begin{array}{l}2 \\
- \\
- \\
-\end{array}$ & $\begin{array}{l}3 \\
0 \\
0 \\
1 \\
1 \\
0 \\
0\end{array}$ & $\begin{array}{r}23 \\
23 \\
3 \\
11 \\
3 \\
1 \\
6\end{array}$ & $\begin{array}{r}64 \\
23 \\
8 \\
15 \\
14 \\
4\end{array}$ & $\begin{array}{r}98 \\
47 \\
3 \\
30 \\
8 \\
6 \\
4\end{array}$ & $\begin{array}{l}- \\
- \\
- \\
-\end{array}$ & $\begin{array}{l}3 \\
0 \\
0 \\
2 \\
0 \\
0 \\
0\end{array}$ & $\begin{array}{r}12 \\
7 \\
6 \\
9 \\
1 \\
1 \\
2\end{array}$ & $\begin{array}{r}59 \\
7 \\
2 \\
40 \\
1 \\
6 \\
3\end{array}$ & $\begin{array}{r}95 \\
40 \\
2 \\
44 \\
2 \\
6 \\
1\end{array}$ \\
\hline $\begin{array}{l}\text { Mid. Atlantic } \\
\text { New Jersey } \\
\text { New York (Upstate) } \\
\text { New York City } \\
\text { Pennsylvania }\end{array}$ & $\begin{array}{r}37 \\
19 \\
3 \\
15\end{array}$ & $\begin{array}{l}88 \\
18 \\
29 \\
19 \\
28\end{array}$ & $\begin{array}{r}201 \\
55 \\
65 \\
49 \\
78\end{array}$ & $\begin{array}{r}1,300 \\
106 \\
367 \\
328 \\
499\end{array}$ & $\begin{array}{r}1,556 \\
375 \\
350 \\
377 \\
454\end{array}$ & $\begin{array}{l}- \\
- \\
-\end{array}$ & $\begin{array}{l}7 \\
1 \\
3 \\
1 \\
0\end{array}$ & $\begin{array}{r}27 \\
12 \\
12 \\
5 \\
8\end{array}$ & $\begin{array}{r}74 \\
12 \\
33 \\
25 \\
4\end{array}$ & $\begin{array}{r}119 \\
47 \\
33 \\
14 \\
25\end{array}$ & $\frac{10}{\frac{9}{1}}$ & $\begin{array}{r}55 \\
19 \\
7 \\
11 \\
15\end{array}$ & $\begin{array}{l}93 \\
38 \\
31 \\
28 \\
36\end{array}$ & $\begin{array}{r}1,000 \\
240 \\
74 \\
175 \\
511\end{array}$ & $\begin{array}{r}729 \\
167 \\
197 \\
321 \\
44\end{array}$ \\
\hline $\begin{array}{l}\text { E.N. Central } \\
\text { Illinois } \\
\text { Indiana } \\
\text { Michigan } \\
\text { Ohio } \\
\text { Wisconsin }\end{array}$ & $\begin{array}{r}39 \\
\overline{-} \\
33 \\
-\end{array}$ & $\begin{array}{r}96 \\
27 \\
8 \\
18 \\
27 \\
12\end{array}$ & $\begin{array}{r}194 \\
71 \\
53 \\
38 \\
49 \\
50\end{array}$ & $\begin{array}{r}1,464 \\
364 \\
84 \\
323 \\
496 \\
197\end{array}$ & $\begin{array}{r}1,530 \\
425 \\
131 \\
290 \\
432 \\
252\end{array}$ & $\begin{array}{l}5 \\
- \\
- \\
3 \\
2\end{array}$ & $\begin{array}{r}12 \\
1 \\
1 \\
3 \\
3 \\
3\end{array}$ & $\begin{array}{l}75 \\
10 \\
14 \\
43 \\
17 \\
20\end{array}$ & $\begin{array}{r}145 \\
29 \\
16 \\
34 \\
39 \\
27\end{array}$ & $\begin{array}{r}149 \\
29 \\
10 \\
23 \\
35 \\
52\end{array}$ & $\frac{13}{-}$ & $\begin{array}{r}82 \\
16 \\
4 \\
5 \\
42 \\
8\end{array}$ & $\begin{array}{r}128 \\
34 \\
39 \\
24 \\
80 \\
33\end{array}$ & $\begin{array}{r}1,105 \\
212 \\
24 \\
102 \\
610 \\
157\end{array}$ & $\begin{array}{r}1,153 \\
381 \\
324 \\
35 \\
306 \\
107\end{array}$ \\
\hline $\begin{array}{l}\text { W.N. Central } \\
\text { lowa } \\
\text { Kansas } \\
\text { Minnesota } \\
\text { Missouri } \\
\text { Nebraska } \\
\text { North Dakota } \\
\text { South Dakota }\end{array}$ & $\begin{array}{r}34 \\
8 \\
10 \\
15 \\
- \\
-1\end{array}$ & $\begin{array}{r}52 \\
7 \\
7 \\
12 \\
13 \\
5 \\
0 \\
4\end{array}$ & $\begin{array}{r}148 \\
16 \\
29 \\
69 \\
48 \\
41 \\
30 \\
22\end{array}$ & $\begin{array}{r}933 \\
140 \\
98 \\
223 \\
198 \\
166 \\
9 \\
99\end{array}$ & $\begin{array}{r}813 \\
144 \\
85 \\
220 \\
217 \\
91 \\
16 \\
40\end{array}$ & $\begin{array}{r}12 \\
3 \\
-8 \\
1 \\
- \\
-\end{array}$ & $\begin{array}{r}12 \\
3 \\
1 \\
2 \\
2 \\
2 \\
0 \\
0\end{array}$ & $\begin{array}{r}58 \\
21 \\
7 \\
21 \\
11 \\
30 \\
28 \\
4\end{array}$ & $\begin{array}{r}148 \\
37 \\
11 \\
40 \\
38 \\
20 \\
-2\end{array}$ & $\begin{array}{r}151 \\
40 \\
10 \\
27 \\
49 \\
13 \\
1 \\
11\end{array}$ & $\begin{array}{r}23 \\
1 \\
4 \\
18 \\
- \\
-\end{array}$ & $\begin{array}{r}14 \\
3 \\
3 \\
3 \\
3 \\
0 \\
0 \\
0\end{array}$ & $\begin{array}{r}42 \\
12 \\
8 \\
25 \\
31 \\
3 \\
9 \\
2\end{array}$ & $\begin{array}{r}287 \\
40 \\
75 \\
29 \\
133 \\
7 \\
1 \\
2\end{array}$ & $\begin{array}{r}366 \\
54 \\
6 \\
88 \\
123 \\
24 \\
71\end{array}$ \\
\hline $\begin{array}{l}\text { S. Atlantic } \\
\text { Delaware } \\
\text { District of Columbia } \\
\text { Florida } \\
\text { Georgia } \\
\text { Maryland } \$ \\
\text { North Carolina } \\
\text { South Carolina } \\
\text { Virginia§ } \\
\text { West Virginia }\end{array}$ & $\begin{array}{r}121 \\
1 \\
75 \\
12 \\
7 \\
6 \\
1 \\
13 \\
6\end{array}$ & $\begin{array}{r}262 \\
2 \\
0 \\
97 \\
38 \\
17 \\
28 \\
18 \\
21 \\
3\end{array}$ & $\begin{array}{r}459 \\
9 \\
4 \\
174 \\
96 \\
37 \\
106 \\
57 \\
88 \\
10\end{array}$ & $\begin{array}{r}3,002 \\
24 \\
1,262 \\
493 \\
219 \\
501 \\
204 \\
241 \\
58\end{array}$ & $\begin{array}{r}2,961 \\
47 \\
28 \\
1,354 \\
481 \\
216 \\
264 \\
260 \\
231 \\
80\end{array}$ & $\begin{array}{l}\frac{10}{-} \\
\frac{4}{1} \\
\frac{-}{4} \\
1\end{array}$ & $\begin{array}{r}14 \\
0 \\
0 \\
2 \\
2 \\
2 \\
2 \\
1 \\
3 \\
0\end{array}$ & $\begin{array}{r}49 \\
2 \\
1 \\
10 \\
8 \\
11 \\
21 \\
3 \\
27 \\
3\end{array}$ & $\begin{array}{r}219 \\
5 \\
64 \\
21 \\
27 \\
54 \\
8 \\
32 \\
8\end{array}$ & $\begin{array}{r}209 \\
6 \\
3 \\
60 \\
16 \\
32 \\
18 \\
14 \\
43 \\
17\end{array}$ & $\begin{array}{r}22 \\
1 \\
8 \\
7 \\
1 \\
4 \\
-1 \\
-\end{array}$ & $\begin{array}{r}50 \\
0 \\
0 \\
11 \\
13 \\
4 \\
5 \\
5 \\
4 \\
0\end{array}$ & $\begin{array}{r}86 \\
7 \\
2 \\
26 \\
40 \\
12 \\
27 \\
31 \\
59 \\
3\end{array}$ & $\begin{array}{r}811 \\
27 \\
171 \\
208 \\
112 \\
157 \\
57 \\
74 \\
5\end{array}$ & $\begin{array}{r}1,339 \\
4 \\
6 \\
383 \\
555 \\
24 \\
35 \\
253 \\
60 \\
19\end{array}$ \\
\hline $\begin{array}{l}\text { E.S. Central } \\
\text { Alabama } \\
\text { Kentucky } \\
\text { Mississippi } \\
\text { Tennessee§ }\end{array}$ & $\begin{array}{r}7 \\
1 \\
1 \\
5\end{array}$ & $\begin{array}{l}60 \\
16 \\
10 \\
13 \\
14\end{array}$ & $\begin{array}{r}140 \\
49 \\
18 \\
57 \\
62\end{array}$ & $\begin{array}{l}650 \\
191 \\
142 \\
125 \\
192\end{array}$ & $\begin{array}{l}737 \\
215 \\
121 \\
179 \\
222\end{array}$ & $\begin{array}{l}- \\
- \\
-\end{array}$ & $\begin{array}{l}5 \\
1 \\
1 \\
0 \\
2\end{array}$ & $\begin{array}{r}12 \\
3 \\
7 \\
1 \\
6\end{array}$ & $\begin{array}{r}54 \\
10 \\
14 \\
3 \\
27\end{array}$ & $\begin{array}{r}87 \\
31 \\
17 \\
4 \\
35\end{array}$ & $\frac{9}{-}$ & $\begin{array}{r}27 \\
5 \\
2 \\
1 \\
15\end{array}$ & $\begin{array}{r}58 \\
18 \\
25 \\
6 \\
48\end{array}$ & $\begin{array}{r}365 \\
64 \\
86 \\
11 \\
204\end{array}$ & $\begin{array}{l}841 \\
191 \\
146 \\
209 \\
295\end{array}$ \\
\hline $\begin{array}{l}\text { W.S. Central } \\
\text { Arkansas } \\
\text { Louisiana } \\
\text { Oklahoma } \\
\text { Texas§ }\end{array}$ & $\begin{array}{r}18 \\
9 \\
9 \\
-\end{array}$ & $\begin{array}{r}142 \\
14 \\
16 \\
15 \\
95\end{array}$ & $\begin{array}{r}1,282 \\
39 \\
54 \\
58 \\
1,197\end{array}$ & $\begin{array}{l}776 \\
152 \\
103 \\
175 \\
346\end{array}$ & $\begin{array}{r}1,115 \\
112 \\
215 \\
138 \\
650\end{array}$ & $\begin{array}{r}1 \\
1 \\
- \\
-\end{array}$ & $\begin{array}{l}6 \\
0 \\
0 \\
1 \\
5\end{array}$ & $\begin{array}{r}63 \\
5 \\
2 \\
19 \\
55\end{array}$ & $\begin{array}{r}45 \\
7 \\
-6 \\
32\end{array}$ & $\begin{array}{r}106 \\
19 \\
2 \\
6 \\
79\end{array}$ & $\begin{array}{r}52 \\
5 \\
6 \\
41\end{array}$ & $\begin{array}{r}96 \\
10 \\
8 \\
3 \\
65\end{array}$ & $\begin{array}{r}948 \\
27 \\
26 \\
43 \\
888\end{array}$ & $\begin{array}{r}1,046 \\
124 \\
57 \\
79 \\
786\end{array}$ & $\begin{array}{r}1,094 \\
124 \\
227 \\
42 \\
701\end{array}$ \\
\hline $\begin{array}{l}\text { Mountain } \\
\text { Arizona } \\
\text { Colorado } \\
\text { Idaho§ } \\
\text { Montana§ } \\
\text { Nevada§ } \\
\text { New Mexico§ } \\
\text { Utah } \\
\text { Wyoming§ }\end{array}$ & $\begin{array}{r}24 \\
7 \\
9 \\
1 \\
-7 \\
- \\
-\end{array}$ & $\begin{array}{r}60 \\
23 \\
12 \\
3 \\
2 \\
4 \\
7 \\
6 \\
1\end{array}$ & $\begin{array}{r}110 \\
43 \\
20 \\
12 \\
7 \\
14 \\
32 \\
19 \\
5\end{array}$ & $\begin{array}{r}865 \\
327 \\
189 \\
56 \\
45 \\
93 \\
70 \\
68 \\
17\end{array}$ & $\begin{array}{r}1,024 \\
270 \\
311 \\
49 \\
36 \\
79 \\
149 \\
100 \\
30\end{array}$ & $\begin{array}{l}3 \\
2 \\
1 \\
- \\
- \\
-\end{array}$ & $\begin{array}{r}10 \\
1 \\
3 \\
2 \\
0 \\
0 \\
1 \\
1 \\
0\end{array}$ & $\begin{array}{r}40 \\
4 \\
18 \\
15 \\
3 \\
3 \\
4 \\
9 \\
2\end{array}$ & $\begin{array}{r}110 \\
12 \\
54 \\
12 \\
6 \\
5 \\
14 \\
6 \\
1\end{array}$ & $\begin{array}{r}142 \\
23 \\
37 \\
29 \\
17 \\
4 \\
18 \\
10 \\
4\end{array}$ & $\begin{array}{l}7 \\
7 \\
- \\
- \\
- \\
- \\
-\end{array}$ & $\begin{array}{r}27 \\
16 \\
3 \\
0 \\
0 \\
3 \\
2 \\
1 \\
0\end{array}$ & $\begin{array}{r}54 \\
35 \\
11 \\
2 \\
5 \\
13 \\
12 \\
3 \\
1\end{array}$ & $\begin{array}{r}395 \\
285 \\
36 \\
2 \\
11 \\
28 \\
30 \\
3 \\
-\end{array}$ & $\begin{array}{r}239 \\
102 \\
27 \\
5 \\
1 \\
77 \\
17 \\
7 \\
3\end{array}$ \\
\hline $\begin{array}{l}\text { Pacific } \\
\text { Alaska } \\
\text { California } \\
\text { Hawaii } \\
\text { Oregon§ } \\
\text { Washington }\end{array}$ & $\begin{array}{r}98 \\
4 \\
78 \\
- \\
16\end{array}$ & $\begin{array}{r}119 \\
1 \\
86 \\
5 \\
7 \\
11\end{array}$ & $\begin{array}{r}534 \\
4 \\
516 \\
15 \\
72 \\
85\end{array}$ & $\begin{array}{r}1,983 \\
20 \\
1,511 \\
91 \\
147 \\
214\end{array}$ & $\begin{array}{r}1,577 \\
17 \\
1,191 \\
76 \\
126 \\
167\end{array}$ & $\begin{array}{l}\frac{6}{2} \\
\frac{-}{4}\end{array}$ & $\begin{array}{r}10 \\
0 \\
5 \\
0 \\
1 \\
3\end{array}$ & $\begin{array}{r}31 \\
1 \\
15 \\
2 \\
8 \\
16\end{array}$ & $\begin{array}{r}110 \\
72 \\
2 \\
8 \\
28\end{array}$ & $\begin{array}{r}72 \\
2 \\
44 \\
3 \\
8 \\
15\end{array}$ & $\begin{array}{l}\frac{14}{9} \\
\frac{-}{5}\end{array}$ & $\begin{array}{r}32 \\
0 \\
27 \\
1 \\
1 \\
2\end{array}$ & $\begin{array}{r}82 \\
1 \\
75 \\
3 \\
10 \\
13\end{array}$ & $\begin{array}{r}439 \\
2 \\
340 \\
7 \\
23 \\
67\end{array}$ & $\begin{array}{r}428 \\
361 \\
16 \\
24 \\
27\end{array}$ \\
\hline $\begin{array}{l}\text { American Samoa } \\
\text { C.N.M.I. } \\
\text { Guam } \\
\text { Puerto Rico } \\
\text { U.S. Virgin Islands }\end{array}$ & $\begin{array}{l}- \\
- \\
-\end{array}$ & $\begin{array}{r}0 \\
0 \\
13 \\
0\end{array}$ & $\begin{array}{r}1 \\
2 \\
40 \\
0\end{array}$ & $\begin{array}{l}- \\
\overline{76} \\
-\end{array}$ & $\begin{array}{r}1 \\
5 \\
210 \\
-\end{array}$ & $\begin{array}{l}- \\
- \\
-\end{array}$ & $\begin{array}{l}0 \\
0 \\
0 \\
0\end{array}$ & $\begin{array}{l}0 \\
0 \\
0 \\
0\end{array}$ & $\begin{array}{l}- \\
- \\
-\end{array}$ & $\begin{array}{l}- \\
- \\
-\end{array}$ & $\begin{array}{l}- \\
- \\
-\end{array}$ & $\begin{array}{l}0 \\
0 \\
0 \\
0\end{array}$ & $\begin{array}{l}2 \\
2 \\
4 \\
0\end{array}$ & $\frac{3}{-}$ & $\begin{array}{l}1 \\
9 \\
7 \\
\end{array}$ \\
\hline
\end{tabular}

C.N.M.I.: Commonwealth of Northern Mariana Islands.

U: Unavailable. - o reported cases. N: Not notifiable. Cum: Cumulative year-to-date counts. Med: Median. Max: Maximum

* Incidence data for reporting year 2008 and 2009 are provisional.

† Includes E. coli O157:H7; Shiga toxin-positive, serogroup non-O157; and Shiga toxin-positive, not serogrouped.

$\S$ Contains data reported through the National Electronic Disease Surveillance System (NEDSS). 
TABLE II. (Continued) Provisional cases of selected notifiable diseases, United States, weeks ending May 30, 2009, and May 24, 2008 (21st week)*

\begin{tabular}{|c|c|c|c|c|c|c|c|c|c|c|}
\hline \multirow[b]{3}{*}{ Reporting area } & \multicolumn{5}{|c|}{ Streptococcal diseases, invasive, group A } & \multicolumn{5}{|c|}{$\begin{array}{l}\text { Streptococcus pneumoniae, invasive disease, nondrug resistant } \\
\text { Age }<5 \text { years }\end{array}$} \\
\hline & \multirow{2}{*}{$\begin{array}{c}\text { Current } \\
\text { week }\end{array}$} & \multicolumn{2}{|c|}{$\begin{array}{l}\text { Previous } \\
52 \text { weeks }\end{array}$} & \multirow{2}{*}{$\begin{array}{l}\text { Cum } \\
2009 \\
\end{array}$} & \multirow{2}{*}{$\begin{array}{l}\text { Cum } \\
2008\end{array}$} & \multirow{2}{*}{$\begin{array}{c}\text { Current } \\
\text { week }\end{array}$} & \multicolumn{2}{|c|}{$\begin{array}{l}\text { Previous } \\
52 \text { weeks }\end{array}$} & \multirow{2}{*}{$\begin{array}{l}\text { Cum } \\
2009\end{array}$} & \multirow{2}{*}{$\begin{array}{l}\text { Cum } \\
2008\end{array}$} \\
\hline & & Med & Max & & & & Med & Max & & \\
\hline United States & 60 & 96 & 237 & 2,569 & 2,855 & 14 & 34 & 121 & 793 & 904 \\
\hline $\begin{array}{l}\text { New England } \\
\text { Connecticut } \\
\text { Maine§ } \\
\text { Massachusetts } \\
\text { New Hampshire } \\
\text { Rhode Island§ } \\
\text { Vermont\$ }\end{array}$ & $\begin{array}{l}= \\
= \\
= \\
=\end{array}$ & $\begin{array}{l}5 \\
0 \\
0 \\
2 \\
1 \\
0 \\
0\end{array}$ & $\begin{array}{r}29 \\
21 \\
3 \\
10 \\
4 \\
8 \\
3\end{array}$ & $\begin{array}{r}151 \\
43 \\
9 \\
60 \\
25 \\
4 \\
10\end{array}$ & $\begin{array}{r}214 \\
54 \\
14 \\
114 \\
15 \\
8 \\
9\end{array}$ & $\begin{array}{l}= \\
= \\
= \\
=\end{array}$ & $\begin{array}{l}1 \\
0 \\
0 \\
1 \\
0 \\
0 \\
0\end{array}$ & $\begin{array}{r}12 \\
11 \\
1 \\
3 \\
1 \\
2 \\
1\end{array}$ & $\begin{array}{l}\frac{21}{-} \\
\frac{15}{4} \\
\frac{4}{2}\end{array}$ & $\begin{array}{r}44 \\
1 \\
35 \\
7 \\
1 \\
-\end{array}$ \\
\hline $\begin{array}{l}\text { Mid. Atlantic } \\
\text { New Jersey } \\
\text { New York (Upstate) } \\
\text { New York City } \\
\text { Pennsylvania }\end{array}$ & $\frac{\frac{8}{4}}{\frac{4}{4}}$ & $\begin{array}{r}18 \\
1 \\
6 \\
4 \\
6\end{array}$ & $\begin{array}{r}38 \\
6 \\
25 \\
12 \\
18\end{array}$ & $\begin{array}{r}478 \\
3 \\
178 \\
95 \\
202\end{array}$ & $\begin{array}{l}608 \\
107 \\
190 \\
118 \\
193\end{array}$ & $\begin{array}{l}\frac{5}{2} \\
3 \\
\mathrm{~N}\end{array}$ & $\begin{array}{l}4 \\
1 \\
2 \\
0 \\
0\end{array}$ & $\begin{array}{r}33 \\
4 \\
17 \\
31 \\
2\end{array}$ & $\begin{array}{r}116 \\
14 \\
61 \\
41 \\
\mathrm{~N}\end{array}$ & $\begin{array}{r}110 \\
33 \\
45 \\
32 \\
\mathrm{~N}\end{array}$ \\
\hline $\begin{array}{l}\text { E.N. Central } \\
\text { Illinois } \\
\text { Indiana } \\
\text { Michigan } \\
\text { Ohio } \\
\text { Wisconsin }\end{array}$ & $\begin{array}{l}5 \\
- \\
1 \\
4\end{array}$ & $\begin{array}{r}17 \\
5 \\
3 \\
3 \\
4 \\
1\end{array}$ & $\begin{array}{l}43 \\
12 \\
23 \\
10 \\
13 \\
10\end{array}$ & $\begin{array}{r}517 \\
138 \\
82 \\
83 \\
143 \\
71\end{array}$ & $\begin{array}{r}569 \\
164 \\
74 \\
105 \\
152 \\
74\end{array}$ & $\begin{array}{l}\frac{2}{-} \\
-1 \\
1 \\
-\end{array}$ & $\begin{array}{l}6 \\
1 \\
0 \\
1 \\
1 \\
0\end{array}$ & $\begin{array}{r}18 \\
5 \\
13 \\
5 \\
6 \\
3\end{array}$ & $\begin{array}{r}115 \\
14 \\
11 \\
34 \\
42 \\
14\end{array}$ & $\begin{array}{r}162 \\
48 \\
17 \\
44 \\
30 \\
23\end{array}$ \\
\hline $\begin{array}{l}\text { W.N. Central } \\
\text { lowa } \\
\text { Kansas } \\
\text { Minnesota } \\
\text { Missouri } \\
\text { Nebraska } \$ \\
\text { North Dakota } \\
\text { South Dakota }\end{array}$ & $\begin{array}{l}\frac{6}{1} \\
\frac{2}{2} \\
\frac{3}{3}\end{array}$ & $\begin{array}{l}6 \\
0 \\
0 \\
0 \\
1 \\
1 \\
0 \\
0\end{array}$ & $\begin{array}{r}37 \\
0 \\
5 \\
34 \\
8 \\
3 \\
2 \\
2\end{array}$ & $\begin{array}{r}218 \\
32 \\
84 \\
58 \\
27 \\
2 \\
15\end{array}$ & $\begin{array}{r}219 \\
25 \\
101 \\
56 \\
19 \\
7 \\
11\end{array}$ & $\begin{array}{l}\bar{Z} \\
\bar{N} \\
= \\
=\end{array}$ & $\begin{array}{l}2 \\
0 \\
0 \\
0 \\
1 \\
0 \\
0 \\
0\end{array}$ & $\begin{array}{r}11 \\
0 \\
1 \\
7 \\
4 \\
1 \\
3 \\
2\end{array}$ & $\begin{array}{r}66 \\
\mathrm{~N} \\
28 \\
28 \\
3 \\
3 \\
4\end{array}$ & $\begin{array}{r}40 \\
N \\
9 \\
20 \\
4 \\
2 \\
5\end{array}$ \\
\hline $\begin{array}{l}\text { S. Atlantic } \\
\text { Delaware } \\
\text { District of Columbia } \\
\text { Florida } \\
\text { Georgia } \\
\text { Maryland } \\
\text { North Carolina } \\
\text { South Carolina } \\
\text { Virginia } \\
\text { West Virginia }\end{array}$ & $\begin{array}{l}20 \\
- \\
5 \\
3 \\
3 \\
4 \\
1 \\
4 \\
-\end{array}$ & $\begin{array}{r}22 \\
0 \\
0 \\
6 \\
5 \\
3 \\
2 \\
1 \\
3 \\
1\end{array}$ & $\begin{array}{r}46 \\
1 \\
2 \\
12 \\
13 \\
10 \\
12 \\
5 \\
9 \\
4\end{array}$ & $\begin{array}{r}568 \\
8 \\
136 \\
139 \\
83 \\
59 \\
36 \\
86 \\
21\end{array}$ & $\begin{array}{r}555 \\
6 \\
6 \\
127 \\
117 \\
102 \\
70 \\
35 \\
73 \\
19\end{array}$ & $\begin{array}{l}\frac{1}{N} \\
- \\
\bar{N} \\
= \\
-\end{array}$ & $\begin{array}{l}7 \\
0 \\
0 \\
1 \\
2 \\
1 \\
0 \\
1 \\
0 \\
0\end{array}$ & $\begin{array}{r}16 \\
0 \\
0 \\
6 \\
6 \\
3 \\
0 \\
6 \\
4 \\
2\end{array}$ & $\begin{array}{r}166 \\
N \\
36 \\
47 \\
33 \\
N \\
27 \\
15 \\
8\end{array}$ & $\begin{array}{r}175 \\
N \\
31 \\
51 \\
34 \\
N \\
28 \\
27 \\
4\end{array}$ \\
\hline $\begin{array}{l}\text { E.S. Central } \\
\text { Alabama } \$ \\
\text { Kentucky } \\
\text { Mississippi } \\
\text { Tennessee }\end{array}$ & $\frac{\bar{N}}{\bar{N}}$ & $\begin{array}{l}4 \\
0 \\
1 \\
0 \\
3\end{array}$ & $\begin{array}{r}10 \\
0 \\
5 \\
0 \\
8\end{array}$ & $\begin{array}{r}107 \\
N \\
19 \\
N \\
88\end{array}$ & $\begin{array}{r}94 \\
N \\
19 \\
N \\
75\end{array}$ & $\begin{array}{l}\bar{N} \\
\mathrm{~N} \\
- \\
-\end{array}$ & $\begin{array}{l}1 \\
0 \\
0 \\
0 \\
1\end{array}$ & $\begin{array}{l}6 \\
0 \\
0 \\
2 \\
6\end{array}$ & $\begin{array}{r}30 \\
\mathrm{~N} \\
\mathrm{~N} \\
\frac{30}{30}\end{array}$ & $\begin{array}{r}57 \\
N \\
N \\
15 \\
42\end{array}$ \\
\hline $\begin{array}{l}\text { W.S. Central } \\
\text { Arkansas } \\
\text { Louisiana } \\
\text { Oklahoma } \\
\text { Texas } \$\end{array}$ & $\begin{array}{r}\frac{15}{2} \\
13\end{array}$ & $\begin{array}{r}10 \\
0 \\
0 \\
2 \\
6\end{array}$ & $\begin{array}{r}75 \\
2 \\
2 \\
16 \\
59\end{array}$ & $\begin{array}{r}235 \\
9 \\
6 \\
82 \\
138\end{array}$ & $\begin{array}{r}225 \\
6 \\
10 \\
57 \\
152\end{array}$ & $\begin{array}{l}\frac{4}{-} \\
1 \\
3\end{array}$ & $\begin{array}{l}6 \\
0 \\
0 \\
1 \\
4\end{array}$ & $\begin{array}{r}46 \\
4 \\
3 \\
7 \\
34\end{array}$ & $\begin{array}{r}145 \\
16 \\
12 \\
28 \\
89\end{array}$ & $\begin{array}{r}134 \\
8 \\
6 \\
42 \\
78\end{array}$ \\
\hline $\begin{array}{l}\text { Mountain } \\
\text { Arizona } \\
\text { Colorado } \\
\text { Idaho§ } \\
\text { Montana§ } \\
\text { Nevada§ } \\
\text { New Mexico§ } \\
\text { Utah } \\
\text { Wyoming }\end{array}$ & $\begin{array}{l}6 \\
1 \\
5 \\
\bar{N} \\
- \\
- \\
-\end{array}$ & $\begin{array}{l}9 \\
3 \\
3 \\
0 \\
0 \\
0 \\
2 \\
1 \\
0\end{array}$ & $\begin{array}{r}22 \\
8 \\
8 \\
2 \\
0 \\
1 \\
7 \\
6 \\
1\end{array}$ & $\begin{array}{r}230 \\
71 \\
90 \\
3 \\
\mathrm{~N} \\
4 \\
40 \\
21 \\
1\end{array}$ & $\begin{array}{r}312 \\
105 \\
77 \\
10 \\
N \\
6 \\
78 \\
31 \\
5\end{array}$ & $\begin{array}{l}\frac{2}{2} \\
\frac{\mathrm{N}}{-} \\
= \\
-\end{array}$ & $\begin{array}{l}4 \\
2 \\
1 \\
0 \\
0 \\
0 \\
0 \\
0 \\
0\end{array}$ & $\begin{array}{r}16 \\
10 \\
4 \\
2 \\
0 \\
1 \\
3 \\
4 \\
1\end{array}$ & $\begin{array}{r}119 \\
69 \\
24 \\
4 \\
\mathrm{~N} \\
11 \\
11 \\
-\end{array}$ & $\begin{array}{r}155 \\
68 \\
35 \\
2 \\
\mathrm{~N} \\
2 \\
24 \\
23 \\
1\end{array}$ \\
\hline $\begin{array}{l}\text { Pacific } \\
\text { Alaska } \\
\text { California } \\
\text { Hawaii } \\
\text { Oregon§ } \\
\text { Washington }\end{array}$ & $\begin{array}{l}\overline{-} \\
\frac{N}{N} \\
N\end{array}$ & $\begin{array}{l}3 \\
0 \\
0 \\
3 \\
0 \\
0\end{array}$ & $\begin{array}{l}9 \\
4 \\
0 \\
8 \\
0 \\
0\end{array}$ & $\begin{array}{r}65 \\
8 \\
N \\
57 \\
N \\
N\end{array}$ & $\begin{array}{r}59 \\
12 \\
N \\
47 \\
N \\
N\end{array}$ & $\frac{\bar{T}}{\bar{N}}$ & $\begin{array}{l}1 \\
0 \\
0 \\
0 \\
0 \\
0\end{array}$ & $\begin{array}{l}3 \\
3 \\
0 \\
2 \\
0 \\
0\end{array}$ & $\begin{array}{r}15 \\
10 \\
N \\
5 \\
N \\
N\end{array}$ & $\begin{array}{r}27 \\
16 \\
N \\
11 \\
N \\
N\end{array}$ \\
\hline $\begin{array}{l}\text { American Samoa } \\
\text { C.N.M.I. } \\
\text { Guam } \\
\text { Puerto Rico } \\
\text { U.S. Virgin Islands }\end{array}$ & $\begin{array}{l}\overline{-} \\
\bar{N} \\
-\end{array}$ & $\begin{array}{l}\frac{0}{0} \\
0 \\
0\end{array}$ & $\begin{array}{l}\frac{8}{0} \\
0 \\
0\end{array}$ & $\begin{array}{l}- \\
\bar{N} \\
-\end{array}$ & $\frac{19}{\bar{N}}$ & $\frac{N}{\bar{N}}$ & $\begin{array}{l}0 \\
0 \\
0 \\
0\end{array}$ & $\begin{array}{l}\frac{0}{0} \\
0 \\
0\end{array}$ & $\frac{\mathrm{N}}{\bar{N}}$ & $\frac{\mathrm{N}}{\bar{N}}$ \\
\hline
\end{tabular}

C.N.M.I.: Commonwealth of Northern Mariana Islands.

U: Unavailable. - - No reported cases. N: Not notifiable. Cum: Cumulative year-to-date counts. Med: Median. Max: Maximum.

* Incidence data for reporting year 2008 and 2009 are provisional.

+ Includes cases of invasive pneumococcal disease, in children aged $<5$ years, caused by $S$. pneumoniae, which is susceptible or for which susceptibility testing is not available (NNDSS event code 11717).

$\S$ Contains data reported through the National Electronic Disease Surveillance System (NEDSS). 
TABLE II. (Continued) Provisional cases of selected notifiable diseases, United States, weeks ending May 30, 2009, and May 24, 2008 (21st week)*

\begin{tabular}{|c|c|c|c|c|c|c|c|c|c|c|c|c|c|c|c|}
\hline \multirow[b]{4}{*}{ Reporting area } & \multicolumn{10}{|c|}{ Streptococcus pneumoniae, invasive disease, drug resistant ${ }^{\dagger}$} & \multirow{2}{*}{\multicolumn{5}{|c|}{ Syphilis, primary and secondary }} \\
\hline & \multirow{3}{*}{$\begin{array}{c}\text { Current } \\
\text { week }\end{array}$} & \multicolumn{4}{|c|}{ All ages } & \multicolumn{5}{|c|}{ Aged $<5$ years } & & & & & \\
\hline & & & & & Cum & Current & & & Cum & Cum & \multirow{2}{*}{$\begin{array}{c}\text { Current } \\
\text { week }\end{array}$} & \multicolumn{2}{|c|}{$\begin{array}{l}\text { Previous } \\
52 \text { weeks } \\
\end{array}$} & \multirow{2}{*}{$\begin{array}{l}\text { Cum } \\
2009 \\
\end{array}$} & \multirow{2}{*}{$\begin{array}{l}\text { Cum } \\
2008\end{array}$} \\
\hline & & Med & Max & 2009 & 2008 & week & Med & Max & 2009 & 2008 & & Med & Max & & \\
\hline United States & 28 & 55 & 276 & 1,445 & 1,702 & 4 & 9 & 20 & 217 & 235 & 80 & 262 & 452 & 4,885 & 4,927 \\
\hline $\begin{array}{l}\text { New England } \\
\text { Connecticut } \\
\text { Maine§ } \\
\text { Massachusetts } \\
\text { New Hampshire } \\
\text { Rhode Island\$ } \\
\text { Vermont } \$\end{array}$ & $\begin{array}{l}- \\
- \\
\bar{z} \\
-\end{array}$ & $\begin{array}{l}1 \\
0 \\
0 \\
0 \\
0 \\
0 \\
0\end{array}$ & $\begin{array}{r}48 \\
48 \\
2 \\
1 \\
3 \\
6 \\
1\end{array}$ & $\begin{array}{l}\frac{26}{7} \\
1 \\
5 \\
5 \\
8\end{array}$ & $\begin{array}{l}\frac{31}{11} \\
\frac{-}{8} \\
12\end{array}$ & $\begin{array}{l}= \\
= \\
= \\
=\end{array}$ & $\begin{array}{l}0 \\
0 \\
0 \\
0 \\
0 \\
0 \\
0\end{array}$ & $\begin{array}{l}5 \\
5 \\
1 \\
1 \\
0 \\
1 \\
0\end{array}$ & $\begin{array}{l}\frac{1}{-} \\
- \\
-\end{array}$ & $\begin{array}{l}-3 \\
- \\
\overline{-} \\
1 \\
2\end{array}$ & $\begin{array}{r}4 \\
1 \\
-3 \\
- \\
-\end{array}$ & $\begin{array}{l}5 \\
1 \\
0 \\
4 \\
0 \\
0 \\
0\end{array}$ & $\begin{array}{r}15 \\
5 \\
2 \\
11 \\
2 \\
5 \\
2\end{array}$ & $\begin{array}{r}135 \\
28 \\
1 \\
92 \\
10 \\
4 \\
-\end{array}$ & $\begin{array}{r}130 \\
8 \\
5 \\
101 \\
6 \\
5 \\
5\end{array}$ \\
\hline $\begin{array}{l}\text { Mid. Atlantic } \\
\text { New Jersey } \\
\text { New York (Upstate) } \\
\text { New York City } \\
\text { Pennsylvania }\end{array}$ & $\begin{array}{l}- \\
\bar{z} \\
-\end{array}$ & $\begin{array}{l}4 \\
0 \\
1 \\
1 \\
1\end{array}$ & $\begin{array}{r}14 \\
0 \\
10 \\
4 \\
8\end{array}$ & $\begin{array}{r}\frac{88}{38} \\
2 \\
48\end{array}$ & $\begin{array}{r}178 \\
32 \\
75 \\
71\end{array}$ & $\begin{array}{l}\bar{z} \\
\bar{z} \\
\bar{z}\end{array}$ & $\begin{array}{l}0 \\
0 \\
0 \\
0 \\
0\end{array}$ & $\begin{array}{l}3 \\
0 \\
2 \\
2 \\
2\end{array}$ & $\frac{\frac{16}{10}}{6}$ & $\frac{\frac{14}{4}}{10}$ & $\begin{array}{r}31 \\
2 \\
24 \\
5\end{array}$ & $\begin{array}{r}32 \\
4 \\
2 \\
22 \\
5\end{array}$ & $\begin{array}{r}51 \\
13 \\
8 \\
36 \\
11\end{array}$ & $\begin{array}{r}749 \\
90 \\
42 \\
482 \\
135\end{array}$ & $\begin{array}{r}701 \\
85 \\
51 \\
437 \\
128\end{array}$ \\
\hline $\begin{array}{l}\text { E.N. Central } \\
\text { illinois } \\
\text { Indiana } \\
\text { Michigan } \\
\text { Ohio } \\
\text { Wisconsin }\end{array}$ & $\begin{array}{c}\frac{7}{N} \\
\frac{1}{1} \\
-\end{array}$ & $\begin{array}{l}9 \\
0 \\
2 \\
0 \\
7 \\
0\end{array}$ & $\begin{array}{r}41 \\
0 \\
32 \\
2 \\
18 \\
0\end{array}$ & $\begin{array}{r}280 \\
N \\
55 \\
15 \\
210 \\
-\end{array}$ & $\begin{array}{r}372 \\
N \\
130 \\
13 \\
229 \\
-\end{array}$ & $\frac{1}{N}$ & $\begin{array}{l}1 \\
0 \\
0 \\
0 \\
1 \\
0\end{array}$ & $\begin{array}{l}7 \\
0 \\
6 \\
1 \\
4 \\
0\end{array}$ & $\begin{array}{r}39 \\
N \\
10 \\
2 \\
27 \\
-\end{array}$ & $\begin{array}{r}51 \\
N \\
16 \\
2 \\
33 \\
-\end{array}$ & $\begin{array}{l}4 \\
3 \\
-1 \\
-\end{array}$ & $\begin{array}{r}24 \\
9 \\
2 \\
4 \\
6 \\
1\end{array}$ & $\begin{array}{r}44 \\
19 \\
10 \\
18 \\
28 \\
4\end{array}$ & $\begin{array}{r}362 \\
96 \\
60 \\
94 \\
92 \\
20\end{array}$ & $\begin{array}{r}460 \\
168 \\
61 \\
86 \\
124 \\
21\end{array}$ \\
\hline $\begin{array}{l}\text { W.N. Central } \\
\text { lowa } \\
\text { Kansas } \\
\text { Minnesota } \\
\text { Missouri } \\
\text { Nebraska } \\
\text { North Dakota } \\
\text { South Dakota }\end{array}$ & $\begin{array}{l}\bar{z} \\
\bar{z} \\
\bar{z} \\
\bar{z}\end{array}$ & $\begin{array}{l}3 \\
0 \\
1 \\
0 \\
1 \\
0 \\
0 \\
0\end{array}$ & $\begin{array}{r}161 \\
0 \\
5 \\
156 \\
5 \\
0 \\
2 \\
2\end{array}$ & $\frac{\frac{56}{17}}{\frac{33}{4}}$ & $\begin{array}{r}128 \\
54 \\
15 \\
54 \\
2 \\
3\end{array}$ & $\begin{array}{l}= \\
= \\
= \\
= \\
=\end{array}$ & $\begin{array}{l}0 \\
0 \\
0 \\
0 \\
0 \\
0 \\
0 \\
0\end{array}$ & $\begin{array}{l}4 \\
0 \\
2 \\
4 \\
1 \\
0 \\
0 \\
2\end{array}$ & $\begin{array}{l}\frac{16}{9} \\
\frac{5}{2} \\
\frac{2}{2}\end{array}$ & $\begin{array}{r}\frac{23}{3} \\
15 \\
2 \\
\frac{2}{3}\end{array}$ & $\begin{array}{l}\frac{1}{1} \\
= \\
= \\
=\end{array}$ & $\begin{array}{l}7 \\
0 \\
0 \\
2 \\
3 \\
0 \\
0 \\
0\end{array}$ & $\begin{array}{r}14 \\
2 \\
3 \\
6 \\
10 \\
2 \\
0 \\
1\end{array}$ & $\begin{array}{r}123 \\
10 \\
10 \\
29 \\
63 \\
10 \\
1\end{array}$ & $\begin{array}{r}171 \\
8 \\
13 \\
40 \\
105 \\
5 \\
-\end{array}$ \\
\hline $\begin{array}{l}\text { S. Atlantic } \\
\text { Delaware } \\
\text { District of Columbia } \\
\text { Florida } \\
\text { Georgia } \\
\text { Maryland } \$ \\
\text { North Carolina } \\
\text { South Carolina } \\
\text { Virginia } \\
\text { West Virginia }\end{array}$ & $\begin{array}{l}\frac{21}{N} \\
16 \\
3 \\
\frac{N}{N} \\
\\
2\end{array}$ & $\begin{array}{r}23 \\
0 \\
0 \\
15 \\
8 \\
0 \\
0 \\
0 \\
0 \\
1\end{array}$ & $\begin{array}{r}53 \\
1 \\
0 \\
36 \\
25 \\
1 \\
0 \\
0 \\
0 \\
13\end{array}$ & $\begin{array}{r}726 \\
8 \\
N \\
447 \\
200 \\
4 \\
N \\
N \\
67\end{array}$ & $\begin{array}{r}692 \\
2 \\
N \\
363 \\
248 \\
4 \\
N \\
N \\
N 5\end{array}$ & $\begin{array}{l}\frac{3}{N} \\
\frac{2}{-} \\
\bar{N} \\
N \\
1\end{array}$ & $\begin{array}{l}4 \\
0 \\
0 \\
3 \\
1 \\
0 \\
0 \\
0 \\
0 \\
0\end{array}$ & $\begin{array}{r}14 \\
0 \\
0 \\
13 \\
5 \\
0 \\
0 \\
0 \\
0 \\
3\end{array}$ & $\begin{array}{r}101 \\
N \\
69 \\
26 \\
N \\
N \\
6\end{array}$ & $\begin{array}{r}\frac{99}{\bar{N}} \\
59 \\
33 \\
1 \\
N \\
N \\
6\end{array}$ & $\begin{array}{r}\frac{21}{3} \\
1 \\
1 \\
\frac{1}{15} \\
1 \\
-\end{array}$ & $\begin{array}{r}62 \\
0 \\
3 \\
21 \\
12 \\
7 \\
7 \\
2 \\
5 \\
0\end{array}$ & $\begin{array}{r}262 \\
4 \\
9 \\
38 \\
227 \\
16 \\
19 \\
6 \\
16 \\
1\end{array}$ & $\begin{array}{r}1,135 \\
14 \\
73 \\
424 \\
148 \\
113 \\
210 \\
39 \\
113 \\
1\end{array}$ & $\begin{array}{r}996 \\
1 \\
51 \\
395 \\
160 \\
128 \\
113 \\
35 \\
110 \\
3\end{array}$ \\
\hline $\begin{array}{l}\text { E.S. Central } \\
\text { Alabama§ } \\
\text { Kentucky } \\
\text { Mississippi } \\
\text { Tennessee }\end{array}$ & $\begin{array}{l}\bar{N} \\
\overline{-}\end{array}$ & $\begin{array}{l}5 \\
0 \\
2 \\
0 \\
3\end{array}$ & $\begin{array}{r}25 \\
0 \\
5 \\
2 \\
22\end{array}$ & $\begin{array}{r}165 \\
N \\
47 \\
118\end{array}$ & $\begin{array}{r}169 \\
N \\
43 \\
1 \\
125\end{array}$ & $\begin{array}{l}\bar{N} \\
\overline{-} \\
-\end{array}$ & $\begin{array}{l}1 \\
0 \\
0 \\
0 \\
0\end{array}$ & $\begin{array}{l}3 \\
0 \\
2 \\
1 \\
3\end{array}$ & $\begin{array}{r}24 \\
N \\
7 \\
-17\end{array}$ & $\begin{array}{r}26 \\
N \\
8 \\
-18\end{array}$ & $\begin{array}{r}\frac{14}{1} \\
1 \\
6 \\
7\end{array}$ & $\begin{array}{r}22 \\
8 \\
1 \\
3 \\
8\end{array}$ & $\begin{array}{l}36 \\
17 \\
10 \\
18 \\
19\end{array}$ & $\begin{array}{r}467 \\
167 \\
24 \\
86 \\
190\end{array}$ & $\begin{array}{r}417 \\
179 \\
39 \\
51 \\
148\end{array}$ \\
\hline $\begin{array}{l}\text { W.S. Central } \\
\text { Arkansas } \\
\text { Louisiana } \\
\text { Oklahoma } \\
\text { Texas } \$\end{array}$ & $\begin{array}{l}\overline{-} \\
\bar{N}\end{array}$ & $\begin{array}{l}1 \\
0 \\
1 \\
0 \\
0\end{array}$ & $\begin{array}{l}7 \\
5 \\
6 \\
0 \\
0\end{array}$ & $\begin{array}{r}48 \\
29 \\
19 \\
N \\
-\end{array}$ & $\begin{array}{r}60 \\
10 \\
50 \\
\mathrm{~N} \\
-\end{array}$ & $\begin{array}{l}\overline{-} \\
\bar{N}\end{array}$ & $\begin{array}{l}0 \\
0 \\
0 \\
0 \\
0\end{array}$ & $\begin{array}{l}3 \\
3 \\
1 \\
0 \\
0\end{array}$ & $\begin{array}{l}9 \\
6 \\
3 \\
N \\
-\end{array}$ & $\begin{array}{r}11 \\
3 \\
8 \\
\mathrm{~N} \\
-\end{array}$ & $\begin{array}{l}2 \\
2 \\
- \\
-\end{array}$ & $\begin{array}{r}48 \\
3 \\
14 \\
1 \\
29\end{array}$ & $\begin{array}{r}80 \\
35 \\
40 \\
7 \\
40\end{array}$ & $\begin{array}{r}916 \\
76 \\
223 \\
23 \\
594\end{array}$ & $\begin{array}{r}823 \\
52 \\
198 \\
37 \\
536\end{array}$ \\
\hline $\begin{array}{l}\text { Mountain } \\
\text { Arizona } \\
\text { Colorado } \\
\text { Idaho§ } \\
\text { Montana§ } \\
\text { Nevada§ } \\
\text { New Mexico§ } \\
\text { Utah } \\
\text { Wyoming§ }\end{array}$ & $\begin{array}{l}\overline{-} \\
\bar{N} \\
\overline{-} \\
\overline{-} \\
\overline{-}\end{array}$ & $\begin{array}{l}2 \\
0 \\
0 \\
0 \\
0 \\
1 \\
0 \\
1 \\
0\end{array}$ & $\begin{array}{l}7 \\
0 \\
0 \\
1 \\
1 \\
4 \\
0 \\
6 \\
2\end{array}$ & $\begin{array}{r}\frac{54}{\bar{N}} \\
\frac{26}{\frac{26}{22}} \\
6\end{array}$ & $\begin{array}{l}\frac{71}{-} \\
\frac{N}{34} \\
\frac{37}{-}\end{array}$ & $\begin{array}{l}\bar{Z} \\
\bar{N} \\
\bar{Z} \\
\bar{Z} \\
\overline{-}\end{array}$ & $\begin{array}{l}0 \\
0 \\
0 \\
0 \\
0 \\
0 \\
0 \\
0 \\
0\end{array}$ & $\begin{array}{l}3 \\
0 \\
0 \\
1 \\
0 \\
2 \\
0 \\
3 \\
0\end{array}$ & $\begin{array}{l}\frac{10}{-} \\
\frac{\mathrm{N}}{6} \\
\frac{6}{4} \\
-\end{array}$ & $\begin{array}{l}\frac{7}{-} \\
\frac{\mathrm{N}}{-} \\
\frac{2}{5} \\
-\end{array}$ & $\begin{array}{l}= \\
= \\
= \\
= \\
=\end{array}$ & $\begin{array}{l}9 \\
4 \\
2 \\
0 \\
0 \\
1 \\
1 \\
0 \\
0\end{array}$ & $\begin{array}{r}20 \\
11 \\
10 \\
2 \\
7 \\
7 \\
5 \\
2 \\
1\end{array}$ & $\begin{array}{r}120 \\
21 \\
39 \\
3 \\
-38 \\
19 \\
-\end{array}$ & $\begin{array}{r}258 \\
135 \\
68 \\
1 \\
29 \\
12 \\
12 \\
1\end{array}$ \\
\hline $\begin{array}{l}\text { Pacific } \\
\text { Alaska } \\
\text { California } \\
\text { Hawaii } \\
\text { Oregon§ } \\
\text { Washington }\end{array}$ & $\frac{\overline{-}}{\bar{N}} \bar{N}$ & $\begin{array}{l}0 \\
0 \\
0 \\
0 \\
0 \\
0\end{array}$ & $\begin{array}{l}1 \\
0 \\
0 \\
1 \\
0 \\
0\end{array}$ & $\begin{array}{l}\frac{2}{N} \\
2 \\
N \\
N\end{array}$ & $\begin{array}{l}1 \\
N \\
1 \\
N \\
N\end{array}$ & $\begin{array}{l}-\bar{c} \\
\frac{N}{N} \\
N\end{array}$ & $\begin{array}{l}0 \\
0 \\
0 \\
0 \\
0 \\
0\end{array}$ & $\begin{array}{l}1 \\
0 \\
0 \\
1 \\
0 \\
0\end{array}$ & $\begin{array}{l}1 \\
N \\
1 \\
N \\
N\end{array}$ & $\begin{array}{l}\frac{1}{\mathrm{~N}} \\
1 \\
\mathrm{~N} \\
\mathrm{~N}\end{array}$ & $\begin{array}{l}\frac{3}{2} \\
\frac{-}{1}\end{array}$ & $\begin{array}{r}46 \\
0 \\
42 \\
0 \\
0 \\
3\end{array}$ & $\begin{array}{r}66 \\
1 \\
59 \\
3 \\
3 \\
9\end{array}$ & $\begin{array}{r}878 \\
803 \\
14 \\
12 \\
49\end{array}$ & $\begin{array}{r}971 \\
883 \\
11 \\
4 \\
73\end{array}$ \\
\hline $\begin{array}{l}\text { American Samoa } \\
\text { C.N.M.I. } \\
\text { Guam } \\
\text { Puerto Rico } \\
\text { U.S. Virgin Islands }\end{array}$ & $\begin{array}{l}\mathrm{N} \\
\frac{-}{-} \\
-\end{array}$ & $\begin{array}{l}\frac{0}{0} \\
0 \\
0\end{array}$ & $\begin{array}{l}\frac{0}{0} \\
0 \\
0 \\
\end{array}$ & $\begin{array}{l}\frac{N}{-} \\
- \\
-\end{array}$ & $\begin{array}{l}\frac{N}{-} \\
- \\
-\end{array}$ & $\begin{array}{l}\text { N } \\
- \\
-\end{array}$ & $\begin{array}{l}0 \\
0 \\
0 \\
0\end{array}$ & $\begin{array}{l}\frac{0}{0} \\
0 \\
0\end{array}$ & $\begin{array}{l}\frac{N}{-} \\
- \\
-\end{array}$ & $\begin{array}{l}\mathrm{N} \\
- \\
-\end{array}$ & $\begin{array}{l}- \\
\frac{7}{6} \\
-\end{array}$ & $\begin{array}{l}0 \\
0 \\
3 \\
0\end{array}$ & $\begin{array}{r}0 \\
0 \\
11 \\
0 \\
\end{array}$ & $\begin{array}{l}- \\
\overline{83} \\
-\end{array}$ & $\begin{array}{l}- \\
\overline{6} \\
-\end{array}$ \\
\hline
\end{tabular}

C.N.M.I.: Commonwealth of Northern Mariana Islands.

U: Unavailable. -: No reported cases. N: Not notifiable. Cum: Cumulative year-to-date counts. Med: Median. Max: Maximum.

* Incidence data for reporting year 2008 and 2009 are provisional.

+ Includes cases of invasive pneumococcal disease caused by drug-resistant S. pneumoniae (DRSP) (NNDSS event code 11720).

$\S$ Contains data reported through the National Electronic Disease Surveillance System (NEDSS). 
TABLE II. (Continued) Provisional cases of selected notifiable diseases, United States, weeks ending May 30, 2009, and May 24, 2008 (21st week)*

\begin{tabular}{|c|c|c|c|c|c|c|c|c|c|c|c|c|c|c|c|}
\hline \multirow[b]{4}{*}{ Reporting area } & & & & & & \multicolumn{10}{|c|}{ West Nile virus disease $^{\dagger}$} \\
\hline & \multicolumn{5}{|c|}{ Varicella (chickenpox) } & \multicolumn{5}{|c|}{ Neuroinvasive } & \multicolumn{5}{|c|}{ Nonneuroinvasive ${ }^{\S}$} \\
\hline & \multirow{2}{*}{$\begin{array}{c}\text { Current } \\
\text { week }\end{array}$} & & $\begin{array}{l}\text { ous } \\
\text { eks }\end{array}$ & & & & & & & & & & & Cum & \\
\hline & & Med & Max & 2009 & 2008 & week & Med & Max & 2009 & 2008 & week & Med & Max & 2009 & 2008 \\
\hline United States & 149 & 366 & 772 & 7,121 & 15,904 & - & 1 & 75 & - & 4 & - & 0 & 77 & - & 14 \\
\hline New England & - & 19 & 49 & 136 & $\begin{array}{l}791 \\
388\end{array}$ & - & 0 & 2 & - & - & - & 0 & 1 & - & 1 \\
\hline $\begin{array}{l}\text { Connecticut } \\
\text { Maineף }\end{array}$ & $\bar{z}$ & $\begin{array}{r}11 \\
1\end{array}$ & 26 & - & $\begin{array}{l}388 \\
139\end{array}$ & $\overline{-}$ & $\begin{array}{l}0 \\
0\end{array}$ & 2 & - & - & - & 0 & 1 & - & 1 \\
\hline Massachusetts & 二 & 0 & 1 & 二 & 139 & 二 & 0 & $\begin{array}{l}0 \\
1\end{array}$ & $\bar{z}$ & 二 & 二 & 0 & 0 & - & 二 \\
\hline New Hampshire & - & 4 & 11 & 93 & 132 & - & 0 & 0 & - & - & - & 0 & 0 & 二 & 二 \\
\hline Rhode Island" & - & 0 & 0 & - & - & - & 0 & 1 & - & - & - & 0 & 0 & - & - \\
\hline Vermont" & - & 4 & 17 & 43 & 132 & - & 0 & 0 & - & - & - & 0 & 0 & - & - \\
\hline Mid. Atlantic & 24 & 39 & 61 & 778 & 1,247 & - & 0 & 8 & - & - & - & 0 & 4 & - & - \\
\hline New Jersey & $\mathrm{N}$ & 0 & 0 & $\mathrm{~N}$ & $\mathrm{~N}$ & - & 0 & 2 & - & - & - & 0 & 1 & - & - \\
\hline New York (Upstate) & $\mathrm{N}$ & 0 & 0 & $\mathrm{~N}$ & $\mathrm{~N}$ & - & 0 & 5 & - & - & - & 0 & 2 & - & - \\
\hline New York City & - & 0 & 0 & - & - & - & 0 & 2 & - & - & - & 0 & 2 & - & - \\
\hline Pennsylvania & 24 & 39 & 61 & 778 & 1,247 & - & 0 & 2 & - & - & - & 0 & 1 & - & - \\
\hline E.N. Central & 72 & 146 & 241 & 3,359 & 3,813 & - & 0 & 8 & - & - & - & 0 & 3 & - & - \\
\hline Illinois & 3 & 35 & 73 & 810 & 539 & - & 0 & 4 & - & - & - & 0 & 2 & - & - \\
\hline Indiana & - & 0 & 14 & 83 & - & - & 0 & 1 & - & - & - & 0 & 1 & - & - \\
\hline Michigan & 26 & 48 & 90 & 1,017 & 1,622 & - & 0 & 4 & - & - & - & 0 & 2 & - & - \\
\hline Ohio & 43 & 42 & 91 & 1,240 & 1,340 & - & 0 & 3 & - & - & - & 0 & 1 & - & - \\
\hline Wisconsin & - & 6 & 50 & 209 & 312 & - & 0 & 2 & - & - & - & 0 & 1 & - & - \\
\hline W.N. Central & 5 & 22 & 114 & 591 & 686 & - & 0 & 6 & - & 1 & - & 0 & 21 & - & - \\
\hline lowa & $\mathrm{N}$ & 0 & 0 & $\mathrm{~N}$ & $\mathrm{~N}$ & - & 0 & 2 & - & - & - & 0 & 1 & - & - \\
\hline Kansas & - & 6 & 22 & 165 & 284 & - & 0 & 2 & - & 1 & - & 0 & 3 & - & - \\
\hline Minnesota & - & 0 & 0 & - & - & - & 0 & 2 & - & - & - & 0 & 4 & - & - \\
\hline Missouri & 5 & 12 & 51 & 390 & 379 & - & 0 & 3 & - & - & - & 0 & 1 & - & - \\
\hline Nebraskaף & $\mathrm{N}$ & 0 & 0 & $\mathrm{~N}$ & $\mathrm{~N}$ & - & 0 & 1 & - & - & - & 0 & 6 & - & - \\
\hline North Dakota & - & 0 & 108 & 36 & - & - & 0 & 2 & - & - & - & 0 & 11 & - & - \\
\hline South Dakota & - & 0 & 4 & - & 23 & - & 0 & 5 & - & - & - & 0 & 6 & - & - \\
\hline S. Atlantic & 35 & 59 & 133 & 1,110 & 2,512 & - & 0 & 4 & - & - & - & 0 & 4 & - & - \\
\hline Delaware & - & 0 & 5 & 2 & 12 & - & 0 & 0 & - & - & - & 0 & 1 & - & - \\
\hline District of Columbia & - & 0 & 1 & - & 17 & - & 0 & 2 & - & - & - & 0 & 1 & - & - \\
\hline $\begin{array}{l}\text { Florida } \\
\text { Finidia }\end{array}$ & 28 & 29 & 67 & 778 & 932 & - & 0 & 2 & - & - & - & 0 & 0 & - & - \\
\hline Georgia & $\mathrm{N}$ & 0 & 0 & $\mathrm{~N}$ & $\mathrm{~N}$ & - & 0 & 1 & - & - & - & 0 & 1 & - & - \\
\hline Marylandף & $\mathrm{N}$ & 0 & 0 & $\mathrm{~N}$ & $\mathrm{~N}$ & - & 0 & 2 & - & - & - & 0 & 3 & - & - \\
\hline North Carolina & $\mathrm{N}$ & 0 & 0 & $\mathrm{~N}$ & $\mathrm{~N}$ & - & 0 & 1 & - & - & - & 0 & 1 & - & - \\
\hline South Carolinall & - & 6 & 39 & 82 & 469 & - & 0 & 0 & - & - & - & 0 & 1 & - & - \\
\hline Virginial & - & 10 & 60 & 28 & 717 & - & 0 & 0 & - & - & - & 0 & 1 & - & - \\
\hline West Virginia & 7 & 10 & 32 & 220 & 365 & - & 0 & 1 & - & - & - & 0 & 0 & - & - \\
\hline E.S. Central & - & 5 & 28 & 17 & 739 & - & 0 & 7 & - & - & - & 0 & 9 & - & 4 \\
\hline Alabamaף & - & 5 & 28 & 16 & 731 & - & 0 & 3 & - & - & - & 0 & 2 & - & 1 \\
\hline Kentucky & $\mathrm{N}$ & 0 & 0 & $\mathrm{~N}$ & $\mathrm{~N}$ & - & 0 & 1 & - & - & - & 0 & 0 & - & - \\
\hline Mississippi & - & 0 & 1 & 1 & 8 & - & 0 & 4 & - & - & - & 0 & 8 & - & 2 \\
\hline Tennesseeף & $N$ & 0 & 0 & $\mathrm{~N}$ & $\mathrm{~N}$ & - & 0 & 2 & - & - & - & 0 & 3 & - & 1 \\
\hline W.S. Central & - & 64 & 355 & 481 & 4,800 & - & 0 & 8 & - & 1 & - & 0 & 7 & - & 5 \\
\hline Arkansas" & - & 4 & 47 & 19 & 395 & - & 0 & 1 & - & - & - & 0 & 1 & - & - \\
\hline Louisiana & - & 1 & 5 & 27 & 41 & - & 0 & 3 & - & - & - & 0 & 5 & - & - \\
\hline Oklahoma & $\mathrm{N}$ & 0 & 0 & $\mathrm{~N}$ & $\mathrm{~N}$ & - & 0 & 1 & - & 1 & - & 0 & 1 & - & 2 \\
\hline Texas? & - & 50 & 345 & 435 & 4,364 & - & 0 & 6 & - & - & - & 0 & 4 & - & 3 \\
\hline Mountain & 9 & 26 & 83 & 593 & 1,261 & - & 0 & 12 & - & 2 & - & 0 & 22 & - & 3 \\
\hline Arizona & - & 0 & 0 & & & - & 0 & 10 & - & 1 & - & 0 & 8 & - & - \\
\hline Colorado & 9 & 11 & 44 & 288 & 516 & - & 0 & 4 & - & - & - & 0 & 10 & - & 1 \\
\hline Idaho"l & $\mathrm{N}$ & 0 & 0 & $\mathrm{~N}$ & $\mathrm{~N}$ & - & 0 & 1 & - & 1 & - & 0 & 6 & - & 1 \\
\hline Montana" & - & 3 & 27 & 70 & 170 & - & 0 & 0 & - & - & - & 0 & 2 & - & - \\
\hline Nevada" & $\mathrm{N}$ & 0 & 0 & $\mathrm{~N}$ & $\mathrm{~N}$ & - & 0 & 2 & - & - & - & 0 & 3 & - & - \\
\hline New Mexico" & - & 2 & 10 & 66 & 126 & - & 0 & 1 & - & - & - & 0 & 1 & - & - \\
\hline Utah & - & 10 & 31 & 169 & 440 & - & 0 & 2 & - & - & - & 0 & 5 & - & - \\
\hline Wyoming? & - & 0 & 1 & - & 9 & - & 0 & 0 & - & - & - & 0 & 2 & - & 1 \\
\hline Pacific & 4 & 2 & 7 & 56 & 55 & - & 0 & 38 & - & - & - & 0 & 23 & - & 1 \\
\hline Alaska & 4 & 1 & 6 & 36 & 20 & - & 0 & 0 & - & - & - & 0 & 0 & - & - \\
\hline California & - & 0 & 0 & - & - & - & 0 & 37 & - & - & - & 0 & 20 & - & 1 \\
\hline Hawaii & - & 1 & 4 & 20 & 35 & - & 0 & 0 & - & - & - & 0 & 0 & - & - \\
\hline Oregon? & $\mathrm{N}$ & 0 & 0 & $\mathrm{~N}$ & $\mathrm{~N}$ & - & 0 & 2 & - & - & - & 0 & 4 & - & - \\
\hline Washington & $\mathrm{N}$ & 0 & 0 & $\mathrm{~N}$ & $\mathrm{~N}$ & - & 0 & 1 & - & - & - & 0 & 1 & - & - \\
\hline American Samoa & $\mathrm{N}$ & 0 & 0 & $\mathrm{~N}$ & $\mathrm{~N}$ & - & 0 & 0 & - & - & - & 0 & 0 & - & - \\
\hline C.N.M.I. & - & - & - & - & - & - & - & - & - & - & - & - & - & - & - \\
\hline Guam & - & 1 & 4 & - & 50 & - & 0 & 0 & - & - & - & 0 & 0 & - & - \\
\hline Puerto Rico & - & 8 & 17 & 114 & 294 & - & 0 & 0 & - & - & - & 0 & 0 & - & - \\
\hline U.S. Virgin Islands & - & 0 & 0 & - & - & - & 0 & 0 & - & - & - & 0 & 0 & - & - \\
\hline
\end{tabular}

C.N.M.I.: Commonwealth of Northern Mariana Islands.

U: Unavailable. - : No reported cases. N: Not notifiable. Cum: Cumulative year-to-date counts. Med: Median. Max: Maximum.

* Incidence data for reporting year 2008 and 2009 are provisional.

† Updated weekly from reports to the Division of Vector-Borne Infectious Diseases, National Center for Zoonotic, Vector-Borne, and Enteric Diseases (ArboNET Surveillance). Data for California serogroup, eastern equine, Powassan, St. Louis, and western equine diseases are available in Table I.

$\S$ Not notifiable in all states. Data from states where the condition is not notifiable are excluded from this table, except starting in 2007 for the domestic arboviral diseases and influenza-associated pediatric mortality, and in 2003 for SARS-CoV. Reporting exceptions are available at http://www.cdc.gov/epo/dphsi/phs/infdis.htm.

" Contains data reported through the National Electronic Disease Surveillance System (NEDSS). 
TABLE III. Deaths in 122 U.S. cities, ${ }^{*}$ week ending May 30, 2009 (21st week)

\begin{tabular}{|c|c|c|c|c|c|c|c|c|c|c|c|c|c|c|c|}
\hline \multirow[b]{2}{*}{ Reporting area } & \multicolumn{6}{|c|}{ All causes, by age (years) } & \multirow[b]{2}{*}{$\begin{array}{l}\text { P\&I' } \\
\text { Total }\end{array}$} & \multirow[b]{2}{*}{ Reporting area } & \multicolumn{6}{|c|}{ All causes, by age (years) } & \multirow[b]{2}{*}{$\begin{array}{l}\text { P\&It } \\
\text { Tota }\end{array}$} \\
\hline & $\begin{array}{c}\text { All } \\
\text { Ages }\end{array}$ & $\geq 65$ & $45-64$ & $25-44$ & $1-24$ & $<1$ & & & $\begin{array}{c}\text { All } \\
\text { Ages }\end{array}$ & $\geq 65$ & $45-64$ & $25-44$ & $1-24$ & $<1$ & \\
\hline New England & 477 & 339 & 104 & 16 & 13 & 5 & 46 & S. Atlantic & 1,256 & 768 & 328 & 97 & 28 & 35 & 68 \\
\hline Boston, MA & 129 & 81 & 32 & 6 & 8 & 2 & 13 & Atlanta, GA & 164 & 104 & 35 & 19 & 5 & 1 & 5 \\
\hline Bridgeport, CT & 30 & 22 & 6 & 1 & 1 & - & 2 & Baltimore, MD & 114 & 56 & 44 & 8 & 2 & 4 & 13 \\
\hline Cambridge, MA & 10 & 7 & 3 & - & - & - & - & Charlotte, NC & 92 & 55 & 23 & 9 & 2 & 3 & 5 \\
\hline Fall River, MA & 22 & 20 & 2 & - & - & - & 2 & Jacksonville, FL & 120 & 75 & 35 & 5 & 3 & 2 & 15 \\
\hline Hartford, CT & 70 & 48 & 16 & 2 & 3 & 1 & 10 & Miami, FL & 92 & 60 & 25 & 5 & 1 & 1 & 5 \\
\hline Lowell, MA & 25 & 14 & 9 & 2 & - & - & 1 & Norfolk, VA & 57 & 35 & 10 & 5 & 1 & 6 & 1 \\
\hline Lynn, MA & 8 & 8 & - & - & - & - & - & Richmond, VA & 55 & 31 & 18 & 2 & 1 & 3 & 2 \\
\hline New Bedford, MA & 27 & 23 & 2 & 1 & - & 1 & - & Savannah, GA & 63 & 47 & 11 & 2 & 1 & 2 & 4 \\
\hline New Haven, CT & 12 & 8 & 3 & - & 1 & - & 1 & St. Petersburg, FL & 40 & 29 & 8 & 3 & - & - & - \\
\hline Providence, RI & 54 & 40 & 11 & 2 & - & 1 & 6 & Tampa, FL & 153 & 104 & 35 & 11 & 3 & - & 8 \\
\hline Somerville, MA & 5 & 4 & 1 & - & - & - & - & Washington, D.C. & 297 & 164 & 83 & 28 & 9 & 13 & 9 \\
\hline Springfield, MA & 19 & 15 & 4 & - & - & - & 2 & Wilmington, DE & 9 & 8 & 1 & - & - & - & 1 \\
\hline Waterbury, CT & 16 & 9 & 7 & - & - & - & 1 & E.S. Central & 766 & 514 & 179 & 46 & 16 & 11 & 58 \\
\hline Worcester, MA & 50 & 40 & 8 & 2 & - & - & 8 & Birmingham, AL & 175 & 117 & 42 & 12 & 3 & 1 & 16 \\
\hline Mid. Atlantic & 1,657 & 1,152 & 354 & 101 & 24 & 25 & 79 & Chattanooga, TN & 80 & 62 & 12 & 3 & 2 & 1 & 3 \\
\hline Albany, NY & 42 & 33 & 5 & 3 & - & 1 & 2 & Knoxville, TN & 75 & 51 & 18 & 2 & 2 & 2 & 6 \\
\hline Allentown, PA & 20 & 16 & 2 & 1 & - & 1 & 3 & Lexington, $\mathrm{KY}$ & 33 & 22 & 8 & 1 & 1 & 1 & 3 \\
\hline Buffalo, NY & 74 & 59 & 7 & 6 & - & 2 & 12 & Memphis, TN & 168 & 110 & 40 & 13 & 2 & 3 & 12 \\
\hline Camden, NJ & 27 & 20 & 4 & 1 & 1 & 1 & 2 & Mobile, AL & 68 & 44 & 17 & 3 & 2 & 2 & 6 \\
\hline Elizabeth, NJ & 16 & 13 & 2 & 1 & - & - & 2 & Montgomery, $\mathrm{AL}$ & 28 & 16 & 8 & 3 & 1 & - & 2 \\
\hline Erie, PA & 48 & 41 & 5 & 2 & - & - & 2 & Nashville, TN & 139 & 92 & 34 & 9 & 3 & 1 & 10 \\
\hline Jersey City, NJ & 21 & 12 & 8 & 1 & - & - & - & W.S. Central & 1,143 & 728 & 285 & 78 & 29 & 23 & 53 \\
\hline New York City, NY & 914 & 627 & 204 & 57 & 16 & 10 & 30 & Austin, TX & 70 & 47 & 16 & 4 & 2 & 1 & 5 \\
\hline Newark, NJ & 24 & 9 & 9 & 2 & 2 & 2 & 1 & Baton Rouge, LA & 60 & 51 & 6 & 2 & 1 & - & - \\
\hline Paterson, NJ & 10 & 7 & 2 & 1 & - & - & - & Corpus Christi, TX & 46 & 29 & 13 & 2 & 1 & 1 & 2 \\
\hline Philadelphia, PA & 115 & 70 & 34 & 6 & 3 & 2 & 4 & Dallas, TX & 130 & 76 & 38 & 8 & 4 & 4 & 7 \\
\hline Pittsburgh, $\mathrm{PA}^{\S}$ & 31 & 17 & 9 & 3 & 2 & - & 4 & El Paso, TX & 65 & 50 & 9 & 4 & 2 & - & 2 \\
\hline Reading, PA & 27 & 20 & 5 & 1 & - & 1 & 2 & Fort Worth, TX & U & U & $U$ & U & $\bar{U}$ & $\mathrm{U}$ & $\bar{U}$ \\
\hline Rochester, NY & 119 & 84 & 21 & 9 & - & 4 & 6 & Houston, TX & 361 & 199 & 112 & 29 & 9 & 12 & 22 \\
\hline Schenectady, NY & 21 & 16 & 4 & - & - & 1 & - & Little Rock, AR & 65 & 46 & 11 & 6 & 1 & 1 & 4 \\
\hline Scranton, PA & 25 & 21 & 3 & 1 & - & - & 2 & New Orleans, LA & U & $\mathrm{U}$ & $U$ & U & U & $\mathrm{U}$ & U \\
\hline Syracuse, NY & 65 & 47 & 14 & 4 & - & - & 3 & San Antonio, TX & 208 & 146 & 42 & 13 & 5 & 2 & 6 \\
\hline Trenton, NJ & 24 & 15 & 8 & 1 & - & - & 1 & Shreveport, LA & 46 & 23 & 15 & 5 & 2 & 1 & 3 \\
\hline Utica, NY & 15 & 13 & 2 & - & - & - & 1 & Tulsa, OK & 92 & 61 & 23 & 5 & 2 & 1 & 2 \\
\hline Yonkers, NY & 19 & 12 & 6 & 1 & - & - & 2 & Mountain & 870 & 566 & 189 & 65 & 30 & 19 & 52 \\
\hline E.N. Central & 1,636 & 1,077 & 396 & 95 & 30 & 38 & 102 & Albuquerque, NM & 101 & 70 & 17 & 7 & 5 & 2 & 9 \\
\hline Akron, $\mathrm{OH}$ & 33 & 21 & 8 & 2 & 1 & 1 & 1 & Boise, ID & 37 & 24 & 9 & 2 & 2 & - & 2 \\
\hline Canton, $\mathrm{OH}$ & 31 & 21 & 8 & 1 & - & 1 & 1 & Colorado Springs, CO & 31 & 21 & 9 & - & 1 & - & - \\
\hline Chicago, IL & 298 & 175 & 80 & 28 & 8 & 7 & 29 & Denver, CO & 68 & 47 & 17 & 1 & 2 & 1 & 3 \\
\hline Cincinnati, $\mathrm{OH}$ & 67 & 50 & 10 & 3 & 2 & 2 & 5 & Las Vegas, NV & 247 & 156 & 68 & 17 & 3 & 3 & 14 \\
\hline Cleveland, $\mathrm{OH}$ & 192 & 135 & 47 & 6 & 4 & - & 6 & Ogden, UT & 24 & 17 & 4 & 2 & 1 & - & - \\
\hline Columbus, $\mathrm{OH}$ & 135 & 97 & 31 & 2 & 1 & 4 & 5 & Phoenix, AZ & 154 & 86 & 34 & 20 & 8 & 5 & 10 \\
\hline Dayton, $\mathrm{OH}$ & 100 & 67 & 28 & 3 & 1 & 1 & 6 & Pueblo, CO & 23 & 18 & 2 & 2 & 1 & - & 1 \\
\hline Detroit, MI & 111 & 55 & 40 & 14 & 2 & - & 9 & Salt Lake City, UT & 127 & 86 & 18 & 10 & 5 & 8 & 10 \\
\hline Evansville, IN & 32 & 23 & 8 & 1 & - & - & 2 & Tucson, AZ & 58 & 41 & 11 & 4 & 2 & - & 3 \\
\hline Fort Wayne, IN & 69 & 51 & 12 & 4 & 1 & 1 & 1 & Pacific & 1,485 & 1,019 & 326 & 79 & 31 & 30 & 127 \\
\hline Gary, IN & 18 & 12 & 4 & - & 2 & - & - & Berkeley, CA & 18 & 14 & 2 & 2 & - & - & 1 \\
\hline Grand Rapids, MI & 40 & 28 & 6 & 5 & 1 & - & 4 & Fresno, CA & 120 & 76 & 36 & 4 & 1 & 3 & 8 \\
\hline Indianapolis, IN & 163 & 94 & 43 & 12 & 3 & 11 & 13 & Glendale, CA & 33 & 28 & 5 & - & - & - & 4 \\
\hline Lansing, MI & 31 & 22 & 3 & 3 & 1 & 2 & - & Honolulu, $\mathrm{HI}$ & 50 & 32 & 12 & 3 & 2 & 1 & 5 \\
\hline Milwaukee, WI & 67 & 49 & 14 & - & 1 & 3 & 6 & Long Beach, CA & 42 & 27 & 10 & 3 & - & 2 & 4 \\
\hline Peoria, IL & 41 & 29 & 8 & 3 & 1 & - & 2 & Los Angeles, CA & 204 & 121 & 52 & 19 & 6 & 6 & 21 \\
\hline Rockford, IL & 61 & 39 & 14 & 4 & 1 & 3 & $\overline{6}$ & Pasadena, CA & 17 & 8 & 5 & 2 & - & 2 & 1 \\
\hline South Bend, IN & 37 & 32 & 4 & 1 & - & - & 2 & Portland, OR & 75 & 52 & 17 & 3 & 2 & 1 & 3 \\
\hline Toledo, $\mathrm{OH}$ & 59 & 38 & 17 & 3 & - & 1 & 1 & Sacramento, CA & 177 & 122 & 39 & 8 & 5 & 3 & 14 \\
\hline Youngstown, $\mathrm{OH}$ & 51 & 39 & 11 & - & - & 1 & 3 & San Diego, CA & 140 & 103 & 24 & 4 & 5 & 4 & 17 \\
\hline W.N. Central & 507 & 344 & 107 & 29 & 16 & 9 & 34 & San Francisco, CA & 105 & 77 & 21 & 4 & - & 3 & 12 \\
\hline Des Moines, IA & 74 & 57 & 15 & 2 & - & - & 1 & San Jose, CA & 176 & 129 & 34 & 9 & 2 & 2 & 16 \\
\hline Duluth, MN & 23 & 21 & 1 & 1 & - & - & 2 & Santa Cruz, CA & 32 & 25 & 4 & 1 & 1 & 1 & - \\
\hline Kansas City, KS & 14 & 6 & 7 & 1 & - & - & 1 & Seattle, WA & 124 & 81 & 29 & 10 & 3 & 1 & 14 \\
\hline Kansas City, MO & 92 & 47 & 22 & 11 & 7 & 5 & 5 & Spokane, WA & 65 & 49 & 15 & 1 & - & - & 6 \\
\hline Lincoln, NE & 34 & 28 & 4 & 1 & - & 1 & 2 & Tacoma, WA & 107 & 75 & 21 & 6 & 4 & 1 & 1 \\
\hline Minneapolis, MN & 46 & 25 & 15 & 3 & 2 & 1 & 4 & Total" & 9,797 & 6,507 & 2,268 & 606 & 217 & 195 & 619 \\
\hline Omaha, NE & 69 & 51 & 13 & 2 & 2 & 1 & 11 & & & & & & & & \\
\hline St. Louis, MO & 57 & 34 & 14 & 4 & 2 & 1 & 6 & & & & & & & & \\
\hline St. Paul, MN & 52 & 40 & 9 & 1 & 2 & - & 1 & & & & & & & & \\
\hline Wichita, KS & 46 & 35 & 7 & 3 & 1 & - & 1 & & & & & & & & \\
\hline
\end{tabular}

U: Unavailable. - No reported cases.

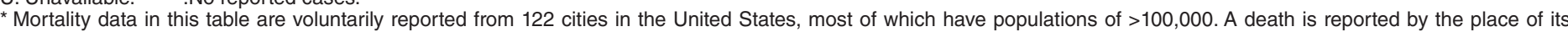
occurrence and by the week that the death certificate was filed. Fetal deaths are not included.

† Pneumonia and influenza.

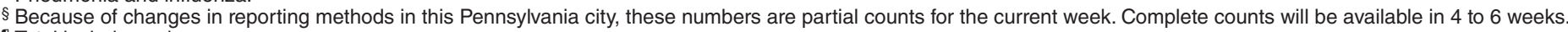
१ी Total includes unknown ages. 

The Morbidity and Mortality Weekly Report (MMWR) Series is prepared by the Centers for Disease Control and Prevention (CDC) and is available free of charge in electronic format. To receive an electronic copy each week, visit MMWR's free subscription page at http://www.cdc.gov/mmwr/mmwrsubscribe.html. Paper copy subscriptions are available through the Superintendent of Documents, U.S. Government Printing Office, Washington, DC 20402; telephone 202-512-1800.

Data in the weekly MMWR are provisional, based on weekly reports to CDC by state health departments. The reporting week concludes at close of business on Friday; compiled data on a national basis are officially released to the public on the following Friday. Data are compiled in the National Center for Public Health Informatics, Division of Integrated Surveillance Systems and Services. Address all inquiries about the MMWR Series, including material to be considered for publication, to Editor, MMWR Series, Mailstop E-90, CDC, 1600 Clifton Rd., N.E., Atlanta, GA 30333 or to mmwrq@cdc.gov.

All material in the MMWR Series is in the public domain and may be used and reprinted without permission; citation as to source, however, is appreciated.

Use of trade names and commercial sources is for identification only and does not imply endorsement by the U.S. Department of Health and Human Services.

References to non-CDC sites on the Internet are provided as a service to $M M W R$ readers and do not constitute or imply endorsement of these organizations or their programs by CDC or the U.S. Department of Health and Human Services. CDC is not responsible for the content of these sites. URL addresses listed in $M M W R$ were current as of the date of publication.

is U.S. Government Printing Office: 2009-523-019/41180 Region IV ISSN: 0149-2195 